\title{
From Simple to Complex: Design of Inorganic \\ Crystal Structures with Topologically Extended \\ Zintl-Klemm Concept
}

Inna V. Medrish, Roman A. Eremin, Vladislav A. Blatov*

Samara Center for Theoretical Materials Science (SCTMS), Samara State Technical University, Molodogvardeyskaya street 244, Samara, 443100 Russian Federation

\section{Supporting Information}


Table S1. Underlying nets in simple sulfates and selenates.

\begin{tabular}{|c|c|c|c|c|}
\hline Underlying net ${ }^{\dagger}$ & 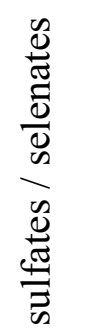 & Sulfates, selenates & 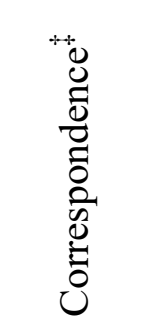 & $\begin{array}{c}\mathrm{XO}_{4} \text { coordination } \\
\text { type }\end{array}$ \\
\hline nia (NiAs) & $11 / 9$ & $\begin{array}{l}\mathrm{MSO}_{4}(\mathrm{M}=\mathrm{Mg}, \mathrm{Mn}, \mathrm{Fe}, \mathrm{Co}, \mathrm{Ni}, \mathrm{Cu}, \\
\mathrm{Cd}, \mathrm{Zn}) \\
\mathrm{MSeO}_{4}(\mathrm{M}=\mathrm{Mg}, \mathrm{Mn}, \mathrm{Co}, \mathrm{Ni}, \mathrm{Cu})\end{array}$ & Normal & $\mathrm{K}^{6}$ \\
\hline $\begin{array}{l}5,6,11 \mathrm{~T} 1 \\
\left(\mathrm{Ni}_{2} \mathrm{In}, \mathrm{BaF}_{2}-\mathrm{HP}\right)\end{array}$ & $8 / 6$ & $\begin{array}{l}\mathrm{M}_{2} \mathrm{SO}_{4}(\mathrm{M}=\mathrm{Li}, \mathrm{Na}, \mathrm{K}, \mathrm{Rb}, \mathrm{Cs}, \mathrm{Tl}) \\
\mathrm{M}_{2} \mathrm{SeO}_{4}(\mathrm{M}=\mathrm{K}, \mathrm{Rb}, \mathrm{Cs}, \mathrm{Tl})\end{array}$ & Anti & $\begin{array}{l}\mathrm{K}^{452}, \mathrm{~K}^{812}(\mathrm{~S}) \\
\mathrm{K}^{461}(\mathrm{Se}), \mathrm{K}^{551}(\mathrm{Se})\end{array}$ \\
\hline $\operatorname{cor}\left(\alpha-\mathrm{Al}_{2} \mathrm{O}_{3}\right)$ & $8 / 0$ & $\begin{array}{l}\mathrm{M}_{2}\left(\mathrm{SO}_{4}\right)_{3}(\mathrm{M}=\mathrm{Al}, \mathrm{Ga}, \mathrm{In}, \mathrm{Sc}, \mathrm{Ti}, \mathrm{Cr}, \\
\mathrm{Fe}, \mathrm{Yb})\end{array}$ & Normal & $\mathrm{K}^{4}$ \\
\hline $7,7 \mathrm{~T} 3(\mathrm{FeB})$ & $7 / 1$ & $\begin{array}{l}\mathrm{MSO}_{4}(\mathrm{M}=\mathrm{Ca}, \mathrm{Sr}, \mathrm{Ba}, \mathrm{Sn}, \mathrm{Pb}, \mathrm{Eu}) \\
\mathrm{BaSeO}_{4}\end{array}$ & Normal & $\begin{array}{l}\mathrm{K}^{25}, \mathrm{~K}^{52}(\mathrm{~S}), \mathrm{K}^{34} \\
(\mathrm{~S}), \mathrm{K}^{61}(\mathrm{~S})\end{array}$ \\
\hline pcu $(\mathrm{NaCl})$ & $6 / 2$ & $\begin{array}{l}\mathrm{MSO}_{4}(\mathrm{M}=\mathrm{Ca}, \mathrm{Sr}, \mathrm{Ba}, \mathrm{Cd}, \mathrm{Hg}) \\
\mathrm{MSeO}_{4}(\mathrm{M}=\mathrm{Cd}, \mathrm{Hg})\end{array}$ & Normal & $\mathrm{K}^{06}(\mathrm{~S}), \mathrm{K}^{42}$ \\
\hline alw $\left(\mathrm{Rh}_{2} \mathrm{O}_{3}-\mathrm{HP}\right)$ & $4 / 3$ & $\begin{array}{l}\mathrm{M}_{2}\left(\mathrm{SO}_{4}\right)_{3}(\mathrm{M}=\mathrm{Fe}, \mathrm{In}, \mathrm{Y}, \mathrm{Er}) \\
\mathrm{M}_{2}\left(\mathrm{SeO}_{4}\right)_{3}(\mathrm{M}=\mathrm{Fe}, \mathrm{Sc}, \mathrm{Yb})\end{array}$ & Normal & $\mathrm{K}^{4}$ \\
\hline pts $(\mathrm{PtS})$ & $5 / 1$ & $\mathrm{MSO}_{4}(\mathrm{M}=\mathrm{Ag}, \mathrm{Pd}, \mathrm{Pt}) \mathrm{PdSeO}_{4}$ & Normal & $\mathrm{K}^{4}$ \\
\hline bcu-7-P2 ${ }_{1} / \mathrm{c}(\mathrm{RhSi})$ & $1 / 4$ & $\begin{array}{l}\mathrm{CaSO} 4-\mathrm{HP}, \mathrm{HT} \\
\mathrm{MSeO}_{4}(\mathrm{M}=\mathrm{Pb}, \mathrm{Ca}, \mathrm{Sr})\end{array}$ & Normal & $\mathrm{K}^{43}$ \\
\hline $\begin{array}{l}\text { dia }(\mathrm{ZnS}, \\
\text { sphalerite })\end{array}$ & $5 / 0$ & $\mathrm{MSO}_{4}(\mathrm{M}=\mathrm{Be}, \mathrm{Zn}, \mathrm{Pd}, \mathrm{Pt})$ & Normal & $\mathrm{K}^{4}$ \\
\hline $4,4,8 \mathrm{~T} 10$ & $3 / 1$ & $\mathrm{M}\left(\mathrm{SO}_{4}\right)_{2}(\mathrm{M}=\mathrm{Ce}, \mathrm{Th}, \mathrm{U}) \mathrm{Ce}\left(\mathrm{SeO}_{4}\right)_{2}$ & & $\mathrm{~K}^{4}$ \\
\hline $5,10 \mathrm{~T} 3\left(\mathrm{TiSi}_{2}\right)$ & $2 / 2$ & $\mathrm{M}_{2} \mathrm{XO}_{4}(\mathrm{M}=\mathrm{Ag}, \mathrm{Na}, \mathrm{X}=\mathrm{S}, \mathrm{Se})$ & Anti & $\mathrm{K}^{82}$ \\
\hline sql & $3 / 0$ & $\mathrm{MSO}_{4}(\mathrm{M}=\mathrm{Pd}, \mathrm{Pt})$ & & $\mathrm{K}^{4}$ \\
\hline sma & $2 / 0$ & $\gamma-\mathrm{CaSO} 4$ & & $\mathrm{~K}^{42}$ \\
\hline hxg-d-8-Pbcm & $2 / 0$ & $\mathrm{BaSO}_{4}-\mathrm{HP}, \mathrm{CaSO}_{4}-\mathrm{HP}$ & & $\mathrm{K}^{44}$ \\
\hline bex; $3,4 \mathrm{~L} 13$ & $2 / 0$ & $\mathrm{MSO}_{4}(\mathrm{M}=\mathrm{Pd}, \mathrm{Pt})$ & & $\mathrm{K}^{4}, \mathrm{~K}^{02}$ \\
\hline nci-6-Cmma & $0 / 2$ & $\mathrm{CaSeO}_{4}$ & & $\mathrm{~K}^{42}$ \\
\hline
\end{tabular}


Table S1 continued

\begin{tabular}{|c|c|c|c|c|}
\hline Underlying net ${ }^{\dagger}$ & 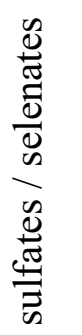 & Sulfates, selenates & 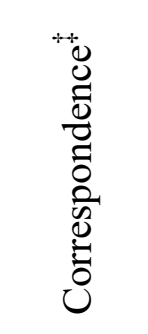 & $\begin{array}{c}\mathrm{XO}_{4} \text { coordination } \\
\text { type }\end{array}$ \\
\hline bcu $(\mathrm{CsCl})$ & $1 / 1$ & $\mathrm{Hg}_{2} \mathrm{XO}_{4}(\mathrm{X}=\mathrm{S}, \mathrm{Se})$ & Normal & $\mathrm{K}^{62}(\mathrm{~S}), \mathrm{K}^{8}(\mathrm{Se})$ \\
\hline Isz (scheelite) & $1 / 1$ & $\mathrm{CaSeO}_{4}-\mathrm{HP}, \mathrm{CaSO}_{4}-\mathrm{HP}$ & Normal & $\mathrm{K}^{8}$ \\
\hline $6,6 \mathrm{~T} 1$ & $1 / 0$ & $\mathrm{SnSO} 4$ & & $\mathrm{~K}^{42}$ \\
\hline $\begin{array}{l}3,4,7 \mathrm{~T} 25\left(\mathrm{PbCl}_{2},\right. \\
\text { cotunnite })^{\S}\end{array}$ & $1 / 0$ & $\alpha-\mathrm{Zr}\left(\mathrm{SO}_{4}\right)_{2}$ & Normal & $\mathrm{T}^{3}, \mathrm{~K}^{4}$ \\
\hline $4,4,5,6,7 \mathrm{~T} 4$ & $1 / 0$ & $\mathrm{Sb}_{2}\left(\mathrm{SO}_{4}\right)_{3}$ & & $\mathrm{~K}^{3 \mathrm{I}}, \mathrm{K}^{4 \mathrm{I}}$ \\
\hline $4,5,7 \mathrm{~T} 12$ & $1 / 0$ & $\mathrm{Nd}_{2}\left(\mathrm{SO}_{4}\right)_{3}$ & & $\mathrm{~K}^{41}, \mathrm{~K}^{22}$ \\
\hline $4,5,7 \mathrm{~T} 26$ & $1 / 0$ & $\mathrm{Bi}_{2}\left(\mathrm{SO}_{4}\right)_{3}$ & & $\mathrm{~K}^{41}, \mathrm{~K}^{22}$ \\
\hline flu $\left(\mathrm{CaF}_{2}\right)$ & $1 / 0$ & $\beta-\mathrm{Li}_{2} \mathrm{SO}_{4}$ & Anti & $\mathrm{K}^{8}$ \\
\hline stc-4,6-P3m1 & $1 / 0$ & $\mathrm{CdSO}_{4}-\mathrm{HT}$ & & $\mathrm{K}^{4}, \mathrm{~T}^{33}$ \\
\hline alb-4,8-Fddd & $1 / 0$ & $\mathrm{Cu}_{2} \mathrm{SO}_{4}$ & & $\mathrm{~K}^{8}$ \\
\hline $2 \mathrm{C} 1$ & $1 / 0$ & $\mathrm{PdSO}_{4}$ & & $\mathrm{~K}^{02}$ \\
\hline $4,8 \mathrm{~T} 14$ & $0 / 1$ & $\mathrm{Li}_{2} \mathrm{SeO}_{4}$ & & $\mathrm{~K}^{8}$ \\
\hline
\end{tabular}

Topological types are ordered by descending of the number of representatives.

Two kinds of correspondence (if any) of the $\mathrm{M}$ cations and $\mathrm{XO}_{4}$ anions to the atoms of a binary compound $\mathrm{M}_{\mathrm{y}} \mathrm{X}_{\mathrm{z}}$ are given: normal or anti if the $\mathrm{M}$ cations in $\mathrm{M}_{\mathrm{y}} \mathrm{X}_{\mathrm{z}}$ match the electropositive $\mathrm{M}$ atoms or electronegative $\mathrm{X}$ atoms, respectively ${ }^{\S}$ In $\mathrm{PbCl}_{2}$ structure two long $(3.65 \AA) \mathrm{Pb}-\mathrm{Cl}$ contacts are ignored. As a result, the cotunnite net is considered as 3,4,7-coordinated, not 4,5,9-coordinated. 
Table S2. Correspondences of the topological types of the $\mathrm{M}_{\mathrm{y}}\left(\mathrm{XO}_{4}\right)_{\mathrm{z}}$ and $\mathrm{M}_{\mathrm{y}} \mathrm{X}_{\mathrm{z}}$ compounds at different conditions.

\begin{tabular}{|c|c|c|c|c|}
\hline & I & II & III & IV \\
\hline $\mathrm{M}_{\mathrm{y}}\left(\mathrm{XO}_{4}\right)_{\mathrm{z}}$ & ambient conditions & HT & ambient conditions & HT \\
\hline $\mathrm{M}_{\mathrm{y}} \mathrm{X}_{\mathrm{z}}$ & $\mathrm{HP}$ & ambient conditions & ambient conditions & $\mathrm{HP}$ \\
\hline $\begin{array}{l}\text { Underlying } \\
\text { net }\end{array}$ & $\begin{array}{l}5,6,11 \mathrm{~T} 1 \\
\mathrm{M}=\mathrm{K}, \mathrm{Rb}, \mathrm{Cs} ; \mathrm{X}=\mathrm{S} \\
\text { pcu } \\
\mathrm{M}=\mathrm{Cd}, \mathrm{Hg}(\mathrm{II}) ; \mathrm{X}=\mathrm{S}, \\
\mathrm{Se} \\
\text { nia } \\
\mathrm{M}=\mathrm{Fe}(\mathrm{II}) ; \mathrm{X}=\mathrm{S} \\
\mathrm{M}=\mathrm{Mn} ; \mathrm{X}=\mathrm{Se}\end{array}$ & $\begin{array}{l}\text { dia } \\
\mathrm{M}=\mathrm{Zn} ; \mathrm{X}=\mathrm{S} \\
\text { pcu } \\
\mathrm{M}=\mathrm{Sr}, \mathrm{Ba} ; \mathrm{X}=\mathrm{S}\end{array}$ & $\begin{array}{l}\text { flu } \\
\mathrm{M}=\mathrm{Li} ; \mathrm{X}=\mathrm{S} \\
\text { dia } \\
\mathrm{M}=\mathrm{Be} ; \mathrm{X}=\mathrm{S} \\
\text { pcu } \\
\mathrm{M}=\mathrm{Ca} ; \mathrm{X}=\mathrm{S} \\
\text { cor } \\
\mathrm{M}=\mathrm{Al}, \mathrm{Yb} ; \mathrm{X}=\mathrm{S} \\
\text { nia } \\
\mathrm{M}=\mathrm{Co}, \mathrm{Ni} ; \mathrm{X}=\mathrm{S}, \\
\mathrm{Se}\end{array}$ & $\begin{array}{l}5,6,11 \mathrm{~T} 1 \\
\mathrm{M}=\mathrm{Na} ; X=S \\
\text { cor } \\
M=\mathrm{In} ; X=S\end{array}$ \\
\hline $\begin{array}{l}\text { Number of } \\
\text { structures }\end{array}$ & $6 \mathrm{SO}_{4} / \mathrm{S} \quad 3 \mathrm{SeO}_{4} / \mathrm{Se}$ & $3 \mathrm{SO}_{4} / \mathrm{S}$ & $7 \mathrm{SO}_{4} / \mathrm{S} \quad 2 \mathrm{SeO}_{4} / \mathrm{Se}$ & $2 \mathrm{SO}_{4} / \mathrm{S}$ \\
\hline
\end{tabular}


Table S3. Correspondences of the topological types of $\mathrm{M}_{\mathrm{y}}\left(\mathrm{SO}_{4}\right)_{\mathrm{z}}$ and $\mathrm{M}_{\mathrm{y}} \mathrm{S}_{\mathrm{z}}$.

\begin{tabular}{|c|c|c|c|c|}
\hline $\begin{array}{l}\text { Underlying nets of } \\
\text { sulfates }\end{array}$ & Sulfates & $\begin{array}{l}\text { Underlying nets } \\
\text { of sulfides }\end{array}$ & Sulfides & $\begin{array}{l}\text { Information of the topology of } \\
\text { some sulfides }^{\dagger}\end{array}$ \\
\hline nia (NiAs) & $\begin{array}{l}\mathrm{MSO}_{4}(\mathrm{M}= \\
\mathrm{Mg}, \mathrm{Mn}, \mathrm{Fe} \\
\mathrm{Co}, \mathrm{Ni}, \mathrm{Cu} \\
\mathrm{Cd}, \mathrm{Zn})\end{array}$ & nia (NiAs) & $\begin{array}{l}\mathrm{MS}(\mathrm{M}= \\
\mathrm{Fe}, \mathrm{Co}, \mathrm{Ni})\end{array}$ & $\begin{array}{l}\mathrm{MS}(\mathrm{M}=\mathrm{Cd}, \mathrm{Zn}, \mathrm{Mn})-\text { dia, lon; } \\
\mathrm{MS}\left(\mathrm{M}=\mathbf{C d} *{ }^{*} \mathrm{Mg}, \mathrm{Mn}\right)-\text { pcu; } \\
\mathrm{MgS}-\text { dia; } \mathrm{MnS}-\text { bcu; NiS - } \\
\text { fnh; } \mathrm{CuS}-\text { there is no structural } \\
\text { data, } \mathrm{CuS}_{2}-\text { pcu, } \mathrm{Cu}_{2} \mathrm{~S}-3,6 \mathrm{~T} 22 \\
\left(\mathrm{Cu}_{2} \mathrm{~S}\right)\end{array}$ \\
\hline $\begin{array}{l}5,6,11 \mathrm{~T} 1\left(\mathrm{Ni}_{2} \mathrm{In},\right. \\
\left.\mathrm{BaF}_{2}-\mathrm{HP}\right)\end{array}$ & $\begin{array}{l}\mathrm{M}_{2} \mathrm{SO}_{4}(\mathrm{M}= \\
\mathrm{Li}, \mathrm{Na}, \mathrm{K}, \mathrm{Rb} \\
\mathrm{Cs}, \mathrm{Tl})\end{array}$ & $\begin{array}{l}5,6,11 \mathrm{~T} 1\left(\mathrm{Ni}_{2} \mathrm{In},\right. \\
\left.\mathrm{BaF}_{2}-\mathrm{HP}\right)\end{array}$ & $\begin{array}{l}\mathrm{M}_{2} \mathrm{~S}(\mathrm{M}= \\
\mathbf{N a}, \mathbf{K}, \mathbf{R b}, \\
\mathbf{C s})\end{array}$ & $\begin{array}{l}\mathrm{M}_{2} \mathrm{~S}(\mathrm{M}=\mathrm{Li}, \mathrm{Na}, \mathrm{K}, \mathrm{Rb})-\mathbf{f l u} \\
\text { (anti); } \mathrm{M}_{2} \mathrm{~S}(\mathrm{M}=\mathbf{L i}, \mathbf{N a}, \mathbf{R b}, \mathrm{Cs}) \\
-\quad 4,5,9 \mathrm{~T} 2 \text { (anticotunite); } \mathrm{Tl}_{2} \mathrm{~S}- \\
\mathbf{k g d}\end{array}$ \\
\hline $\begin{array}{l}7,7 \mathrm{~T} 3(\mathrm{FeB} \text { or } \\
\mathrm{CoB})\end{array}$ & $\begin{array}{l}\mathrm{MSO}_{4}(\mathrm{M}= \\
\mathrm{Ca}, \mathrm{Sr}, \mathrm{Ba} \\
\mathrm{Sn}, \mathrm{Pb}, \mathrm{Eu})\end{array}$ & - & - & $\begin{array}{l}\mathrm{MS}(\mathrm{M}=\mathrm{Ca}, \mathrm{Sr}, \mathrm{Ba}, \mathrm{Pb}, \mathbf{P b} \\
\mathrm{Sn}, \mathrm{Eu})-\mathbf{p c u} ; \mathrm{MS}(\mathrm{M}=\mathbf{C a}, \\
\mathrm{Sr}, \mathbf{B a}, \mathbf{P b})-\mathbf{b c u}(\mathrm{CsCl}) ; \mathrm{SnS} \\
\text { - dia; MS }(\mathrm{M}=\mathrm{Sn}, \mathrm{Pb})-\mathrm{SP} \\
\text { 2-periodic net; PbS - sev; EuS } \\
\text { - 5,6L18 }\end{array}$ \\
\hline $\begin{array}{l}\text { cor } \\
\left(\alpha-\mathrm{Al}_{2} \mathrm{O}_{3}\right)\end{array}$ & $\begin{array}{l}\mathrm{M}_{2}\left(\mathrm{SO}_{4}\right)_{3}(\mathrm{M} \\
=\mathrm{Al}, \mathrm{Ga}, \mathrm{In} \\
\mathrm{Sc}, \mathrm{Ti}, \mathrm{Cr}, \mathrm{Fe}, \\
\mathrm{Yb})\end{array}$ & $\begin{array}{l}\text { cor } \\
\left(\alpha-\mathrm{Al}_{2} \mathrm{O}_{3}\right)\end{array}$ & $\begin{array}{l}\mathrm{M}_{2} \mathrm{~S}_{3}(\mathrm{M}= \\
\mathrm{Al}, \mathrm{In}, \mathrm{Yb})\end{array}$ & $\begin{array}{l}\alpha-\text { and HT- } \mathrm{Al}_{2} \mathrm{~S}_{3}-(\text { topology } \\
\left.\mathrm{Al}_{2} \mathrm{~S}_{3}\right) ; \mathrm{Al}_{2} \mathrm{~S}_{3}, \mathrm{In}_{2} \mathrm{~S}_{3}-\left(\mathrm{In}_{2} \mathrm{~S}_{3}\right) ; \\
\mathrm{Ga}_{2} \mathrm{~S}_{3}-\text { bbe-3,3-Imma; } \mathrm{Cr}_{2} \mathrm{~S}_{3}- \\
\left(\mathrm{Cr}_{2} \mathrm{~S}_{3}\right) ; \text { for } \mathrm{Fe}_{2} \mathrm{~S}_{3} \text { and } \mathrm{Ti}_{2} \mathrm{~S}_{3}- \\
\text { there is no structural data; } \mathrm{Sc}_{2} \mathrm{~S}_{3}- \\
\left(\mathrm{Er}_{2} \mathrm{Se}_{3}\right) ; \mathrm{Yb}_{2} \mathrm{~S}_{3}-\left(\mathrm{Yb}_{2} \mathrm{~S}_{3}, \mathrm{U}_{2} \mathrm{~S}_{3} \text {, }\right. \\
\text { bix/bixbyite) }\end{array}$ \\
\hline pcu $(\mathrm{NaCl})$ & $\begin{array}{l}\mathrm{MSO}_{4}(\mathrm{M}= \\
\mathrm{Ca}, \mathrm{Sr}, \mathrm{Ba} \\
\mathrm{Cd}, \mathrm{Hg})\end{array}$ & pcu $(\mathrm{NaCl})$ & $\begin{array}{l}\mathrm{MS}(\mathrm{M}= \\
\mathrm{Ca}, \mathrm{Sr}, \mathrm{Ba} \\
\mathbf{C d}, \mathbf{H g})\end{array}$ & $\mathrm{CdS}$ - lon, dia; $\mathrm{HgS}$ - dia \\
\hline alw $\left(\mathrm{Rh}_{2} \mathrm{O}_{3}\right.$-HP) & $\begin{array}{l}\mathrm{M}_{2}\left(\mathrm{SO}_{4}\right)_{3}(\mathrm{M} \\
=\mathrm{Fe}, \mathrm{In}, \mathrm{Y} \\
\mathrm{Er})\end{array}$ & - & - & $\begin{array}{l}\mathrm{Y}_{2} \mathrm{~S}_{3}-\left(\mathrm{Er}_{2} \mathrm{~S}_{3}, \mathrm{U}_{2} \mathrm{~S}_{3}\right) ; \mathrm{Er}_{2} \mathrm{~S}_{3}- \\
\left(\mathrm{Er}_{2} \mathrm{~S}_{3}\right) ; \mathbf{E r}_{2} \mathrm{~S}_{3}-\left(\mathrm{U}_{2} \mathrm{~S}_{3}\right)\end{array}$ \\
\hline $\begin{array}{l}\text { dia }(\mathrm{ZnS}, \\
\text { sphalerite) }\end{array}$ & $\begin{array}{l}\mathrm{MSO}_{4}(\mathrm{M}= \\
\mathrm{Be}, \mathrm{Zn})\end{array}$ & $\begin{array}{l}\text { dia }(\mathrm{ZnS}, \\
\text { sphalerite) }\end{array}$ & $\begin{array}{l}\text { MS }(\mathrm{M}= \\
\mathrm{Be}, \mathrm{Zn})\end{array}$ & $\mathrm{ZnS}$ - lon \\
\hline $4,4,8 \mathrm{~T} 10$ & $\begin{array}{l}\mathrm{M}\left(\mathrm{SO}_{4}\right)_{2}(\mathrm{M} \\
=\mathrm{Ce}, \mathrm{Th}, \mathrm{U})\end{array}$ & - & - & $\begin{array}{l}\mathrm{CeS}_{2}-5,6,8 \mathrm{~T} 17 \text { and } \mathrm{GdO}_{2} ; \mathrm{ThS}_{2}, \\
\beta-\mathrm{US}_{2}-\mathrm{PbCl}_{2} ; \gamma-\mathrm{US}_{2}-\mathrm{BaCl}_{2}\end{array}$ \\
\hline $5,10 \mathrm{~T} 3\left(\mathrm{TiSi}_{2}\right)$ & $\begin{array}{l}\mathrm{M}_{2} \mathrm{SO}_{4}(\mathrm{M}= \\
\mathrm{Ag}, \mathrm{Na})\end{array}$ & - & - & $\begin{array}{l}\beta-\mathrm{Ag}_{2} \mathrm{~S}(\mathrm{HT})-\mathrm{PbCl}_{2} ; \mathbf{A g}_{2} \mathrm{~S}- \\
\mathrm{BaBr}_{2}\end{array}$ \\
\hline pts $(\mathrm{PtS})$ & $\begin{array}{l}\mathrm{MSO}_{4}(\mathrm{M}= \\
\mathrm{Ag}, \mathrm{Pd})\end{array}$ & - & - & $\begin{array}{l}\text { PdS - pds; AgS - there is no } \\
\text { structural data }\end{array}$ \\
\hline $\begin{array}{l}3,4,7 \mathrm{~T} 25\left(\mathrm{PbCl}_{2},\right. \\
\text { cotunnite })^{\ddagger}\end{array}$ & $\alpha-\mathrm{Zr}\left(\mathrm{SO}_{4}\right)_{2}$ & - & 一 & $\mathrm{ZrS}_{2}-\mathbf{k g d}$ \\
\hline $4,4,5,6,7 \mathrm{~T} 4$ & $\mathrm{Sb}_{2}\left(\mathrm{SO}_{4}\right)_{3}$ & - & - & $\mathrm{Sb}_{2} \mathrm{~S}_{3}-3,3,5,5,6 \mathrm{~L} 1$ \\
\hline $4,5,7 \mathrm{~T} 12$ & $\mathrm{Nd}_{2}\left(\mathrm{SO}_{4}\right)_{3}$ & - & - & $\mathrm{Nd}_{2} \mathrm{~S}_{3}-\left(\mathrm{Dy}_{2} \mathrm{~S}_{3}\right)$ \\
\hline flu $\left(\mathrm{CaF}_{2}\right)$ & $\beta-\mathrm{Li}_{2} \mathrm{SO}_{4}$ & flu $\left(\mathrm{CaF}_{2}\right)$ & $\mathrm{Li}_{2} \mathrm{~S}$ & \\
\hline
\end{tabular}

${ }^{\dagger}$ The sulfides that have the specified topology under high pressure are highlighted by bold font.

${ }^{\ddagger}$ See the remark to Table 1. 
Table S4. Correspondences of the topological types of $\mathrm{M}_{\mathrm{y}}\left(\mathrm{SeO}_{4}\right)_{\mathrm{z}}$ and $\mathrm{M}_{\mathrm{y}} \mathrm{Se}_{\mathrm{z}}$.

\begin{tabular}{|c|c|c|c|c|}
\hline $\begin{array}{l}\text { Underlying } \\
\text { nets of } \\
\text { selenates }\end{array}$ & Selenates & $\begin{array}{l}\text { Underlying } \\
\text { nets of } \\
\text { selenides }\end{array}$ & Selenides $^{\dagger}$ & $\begin{array}{l}\text { Information of the } \\
\text { topology of some } \\
\text { selenides }\end{array}$ \\
\hline nia $(\mathrm{NiAs})$ & $\begin{array}{l}\mathrm{MSeO}_{4} \\
(\mathrm{M}=\mathrm{Mg}, \mathrm{Mn} \\
\mathrm{Co}, \mathrm{Ni}, \mathrm{Cu})\end{array}$ & nia (NiAs) & $\begin{array}{l}\text { MSe } \\
(\mathrm{M}=\mathbf{M n} *, \mathbf{F e}, \mathrm{Co}, \\
\mathrm{Ni})\end{array}$ & $\begin{array}{l}\mathrm{MgSe}-\text { lon, dia, pcu; } \\
\text { CuSe - there is no } \\
\text { structural data }\end{array}$ \\
\hline \multirow{2}{*}{$\begin{array}{l}5,6,11 \mathrm{~T} 1 \\
\left(\mathrm{Ni}_{2} \mathrm{In}, \mathrm{BaF}_{2-}\right. \\
\mathrm{HP})\end{array}$} & \multirow{2}{*}{$\begin{array}{l}\mathrm{M}_{2} \mathrm{SeO}_{4} \\
(\mathrm{M}=\mathrm{K}, \mathrm{Rb}, \mathrm{Cs}, \\
\mathrm{Tl})\end{array}$} & $\begin{array}{l}\text { flu }\left(\mathrm{CaF}_{2}\right) \\
\text { anti }\end{array}$ & $\begin{array}{l}\mathrm{M}_{2} \mathrm{Se} \\
(\mathrm{M}=\mathrm{K}, \mathrm{Rb})\end{array}$ & \multirow[t]{2}{*}{$\begin{array}{l}\mathrm{Tl}_{2} \mathrm{Se} \text { there is no } \\
\text { structural data }\end{array}$} \\
\hline & & $\begin{array}{l}4,5,9 \mathrm{~T} 2 \\
\left(\mathrm{PbCl}_{2}\right) \\
\text { anti } \\
5,10 \mathrm{~T} 3 \\
\left(\mathrm{TiSi}_{2}\right) \\
\text { anti }\end{array}$ & $\mathrm{Cs}_{2} \mathrm{Se}$ & \\
\hline $\begin{array}{l}\text { alw }\left(\mathrm{Rh}_{2} \mathrm{O}_{3^{-}}\right. \\
\mathrm{HP})\end{array}$ & $\begin{array}{l}\mathrm{M}_{2}\left(\mathrm{SeO}_{4}\right)_{3} \\
(\mathrm{M}=\mathrm{Fe}, \mathrm{Sc}, \mathrm{Yb})\end{array}$ & $\begin{array}{l}4,4,6,6 \mathrm{~T} 8 \\
\left(\mathrm{Er}_{2} \mathrm{Se}_{3}\right) \\
\text { normal } \\
\end{array}$ & $\begin{array}{l}\mathrm{M}_{2} \mathrm{Se}_{3} \\
(\mathrm{M}=\mathrm{Sc}, \mathrm{Yb})\end{array}$ & $\begin{array}{lll}\mathrm{Fe}_{2} \mathrm{Se}_{3} \text { there is no } \\
\text { structural data }\end{array}$ \\
\hline $\begin{array}{l}\text { bcu-7-P2 }{ }_{1} / \mathbf{c} \\
(\mathrm{RhSi})\end{array}$ & $\begin{array}{l}\mathrm{MSeO}_{4} \\
(\mathrm{M}=\mathrm{Ca}, \mathrm{Sr}, \mathrm{Pb})\end{array}$ & bcu & $\begin{array}{l}\text { MSe } \\
(\mathrm{M}=\mathbf{C a}, \mathbf{S r}, \mathbf{P b})\end{array}$ & $\begin{array}{l}\mathrm{PbSe}-\text { pcu, SP } 2- \\
\text { periodic net }(4,4) \text { Ia; } \\
\mathrm{SnS} \\
\mathrm{SrSe}-\text { pcu }\end{array}$ \\
\hline $\begin{array}{l}5,10 \mathrm{~T} 3 \\
\left(\mathrm{TiSi}_{2}\right)\end{array}$ & $\begin{array}{l}\mathrm{M}_{2} \mathrm{SeO}_{4} \\
(\mathrm{M}=\mathrm{Ag}, \mathrm{Na})\end{array}$ & $\begin{array}{l}\text { flu }\left(\mathrm{CaF}_{2}\right) \\
\text { anti }\end{array}$ & $\mathrm{Na}_{2} \mathrm{Se}$ & $\begin{array}{l}\mathrm{Ag}_{2} \mathrm{Se} \\
\left(\mathrm{Ag}_{2} \mathrm{Se}\right)\end{array}$ \\
\hline \multirow{2}{*}{$\begin{array}{l}7,7 \mathrm{~T} 3(\mathrm{FeB} \\
\text { or } \mathrm{CoB})\end{array}$} & \multirow[t]{2}{*}{$\mathrm{BaSeO}_{4}$} & pcu $(\mathrm{NaCl})$ & $\mathrm{BaSe}$ & \\
\hline & & bcu & BaSe & \\
\hline pcu $(\mathrm{NaCl})$ & $\mathrm{HgSeO}_{4}$ & pcu $(\mathrm{NaCl})$ & HgSe & $\mathrm{HgSe}-\mathbf{d i a}$ \\
\hline pts (PtS) & $\mathrm{PdSeO}_{4}$ & $\begin{array}{ll}\text { pds, } & \text { pse } \\
(\mathrm{PdSe}) & \\
\end{array}$ & $\mathrm{PdSe}$ & \\
\hline $4,4,8 \mathrm{~T} 10$ & $\mathrm{Ce}\left(\mathrm{SeO}_{4}\right)_{2}$ & $\begin{array}{l}4,5,9 \mathrm{~T} 3 \\
\left(\mathrm{GdO}_{2}\right) \\
\text { normal }\end{array}$ & $\mathrm{CeSe}_{2}$ & \\
\hline $4,8 \mathrm{~T} 14$ & $\mathrm{Li}_{2} \mathrm{SeO}_{4}$ & $\begin{array}{l}\text { flu }\left(\mathrm{CaF}_{2}\right) \\
\text { anti }\end{array}$ & $\mathrm{Li}_{2} \mathrm{Se}$ & \\
\hline
\end{tabular}

${ }^{\dagger}$ The selenides that have the specified topology under high pressure are highlighted by bold font. 

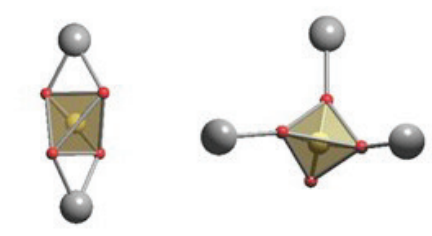

$\mathrm{K}^{02}$

$\mathrm{PtSO}_{4}$ [1]

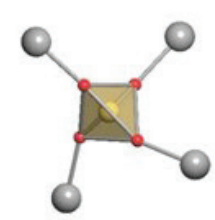

$\mathrm{K}^{4}$

$\mathrm{Ti}_{2}\left(\mathrm{SO}_{4}\right)_{3}$ [3]

$\mathrm{Ce}\left(\mathrm{SeO}_{4}\right)_{2}[4]$

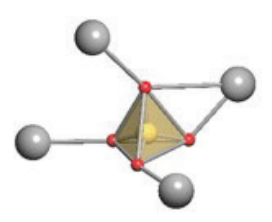

$\mathrm{K}^{31}$

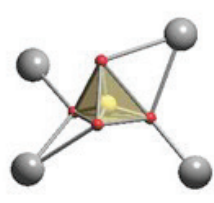

$\mathrm{K}^{22}$

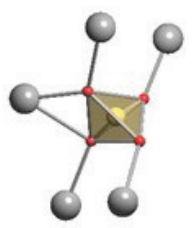

$\mathrm{K}^{41}$

$\mathrm{Sb}_{2}\left(\mathrm{SO}_{4}\right)_{3}[5]$

$\mathrm{Bi}_{2}\left(\mathrm{SO}_{4}\right)_{3}[6]$

$\mathrm{Bi}_{2}\left(\mathrm{SO}_{4}\right)_{3}$ [6]

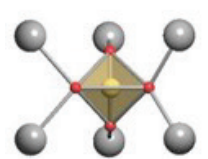

$\mathbf{K}^{6}$

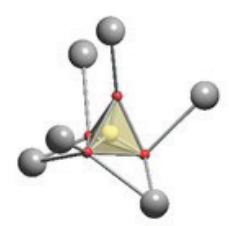

$\mathrm{K}^{42}$

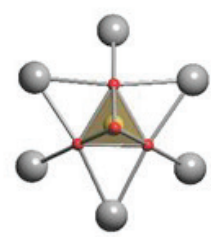

$\mathbf{T}^{33}$

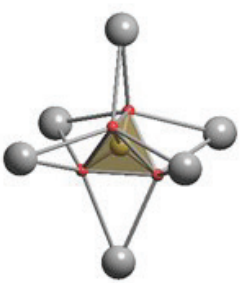

$\mathbf{K}^{06}$

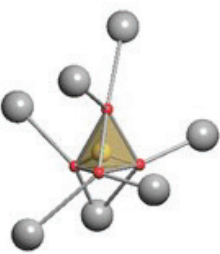

$\mathrm{K}^{61}$

$\mathrm{SnSO}_{4}[13]$

a-BaSO 4 , HT [12] mineral: barite high

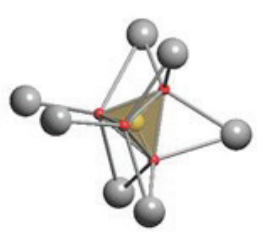

$\mathrm{K}^{25}$

$\mathrm{PbSO}_{4}$ [16]

$\mathrm{BaSeO}_{4}$ [17]

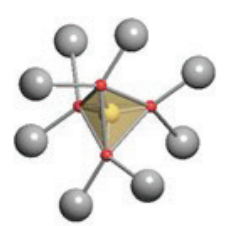

$\mathrm{K}^{8}$

$\mathrm{Cu}_{2} \mathrm{SO}_{4}$ [18]

$\mathrm{Li}_{2} \mathrm{SeO}_{4}$ [19]

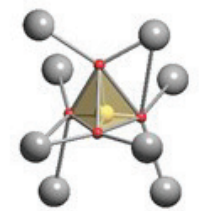

$\mathrm{K}^{62}$

$\mathrm{Hg}_{2} \mathrm{SO}_{4}$ [20]

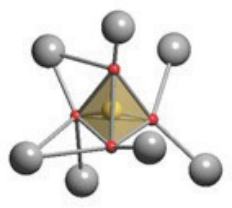

$K^{52}$

$\mathrm{SnSO}_{4}[13]$

$\mathrm{PbSeO}_{4}$ [15]

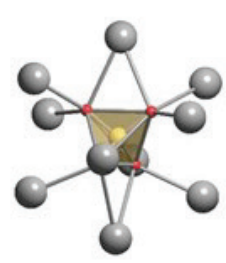

$\mathrm{K}^{82}$

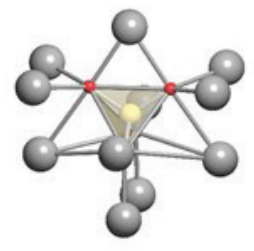

$\mathrm{K}^{812}$

$\mathrm{Ag}_{2} \mathrm{SO}_{4}$ [22] $\mathrm{Na}_{2} \mathrm{SeO}_{4}$ [23]

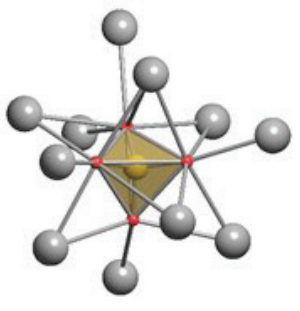

$K^{551}$

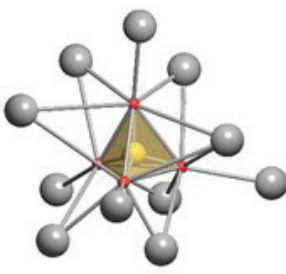

$K^{461}$

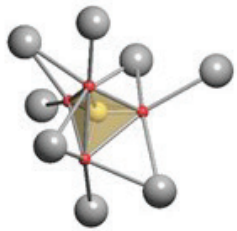

$\mathrm{K}^{44}$

$\mathrm{BaSO}_{4}$ [21] mineral: barite

Figure S1. Coordination modes of sulfate and selenate groups. 

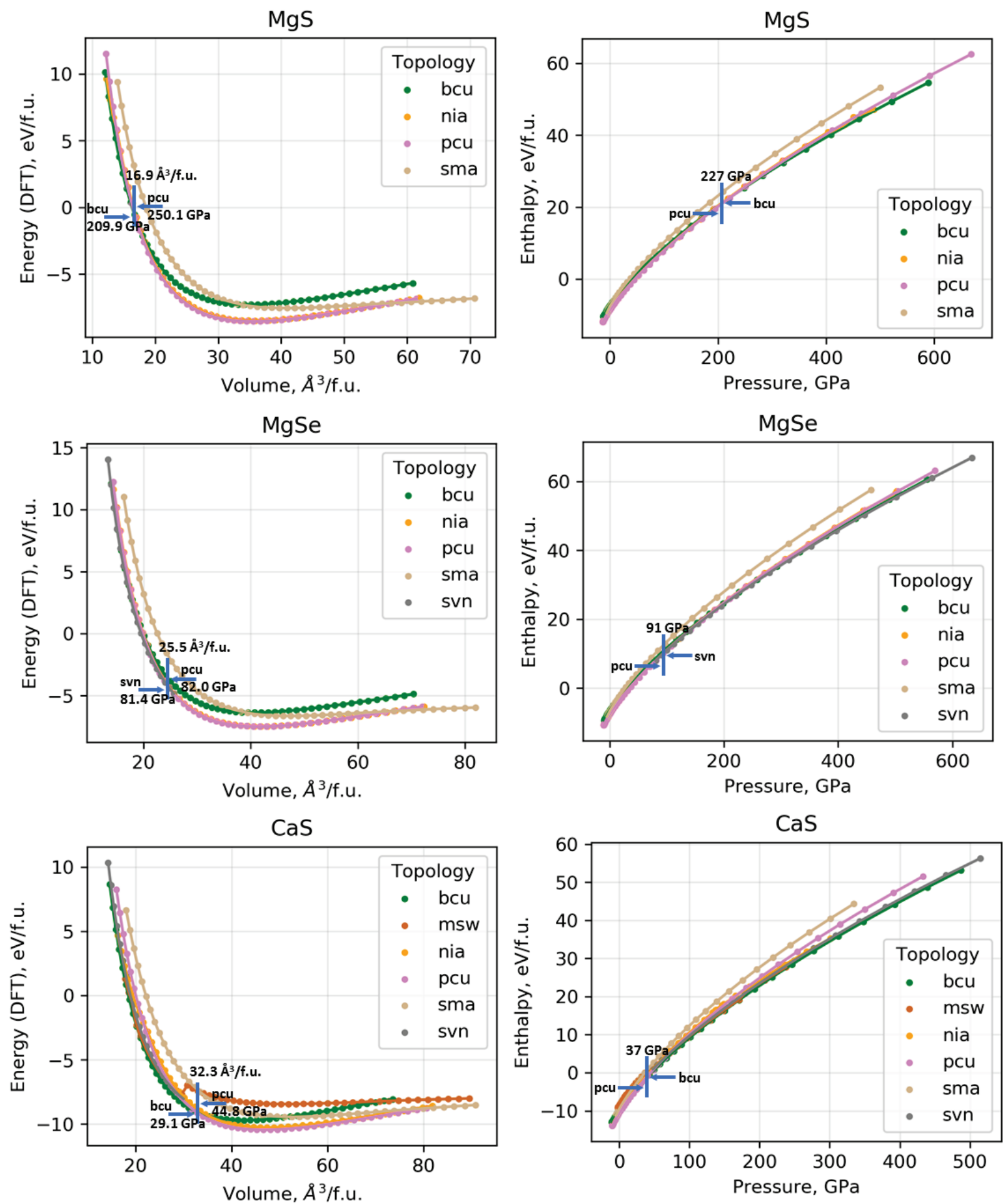

Figure S2.DFT-derived equations of state (left) and calculated dependencies of enthalpy on pressure (right) for the $\mathrm{MgS}, \mathrm{MgSe}$ and $\mathrm{CaS}$ phases. Parameters of phase transitions are given for both used protocols. The figure is continued on the next page. 

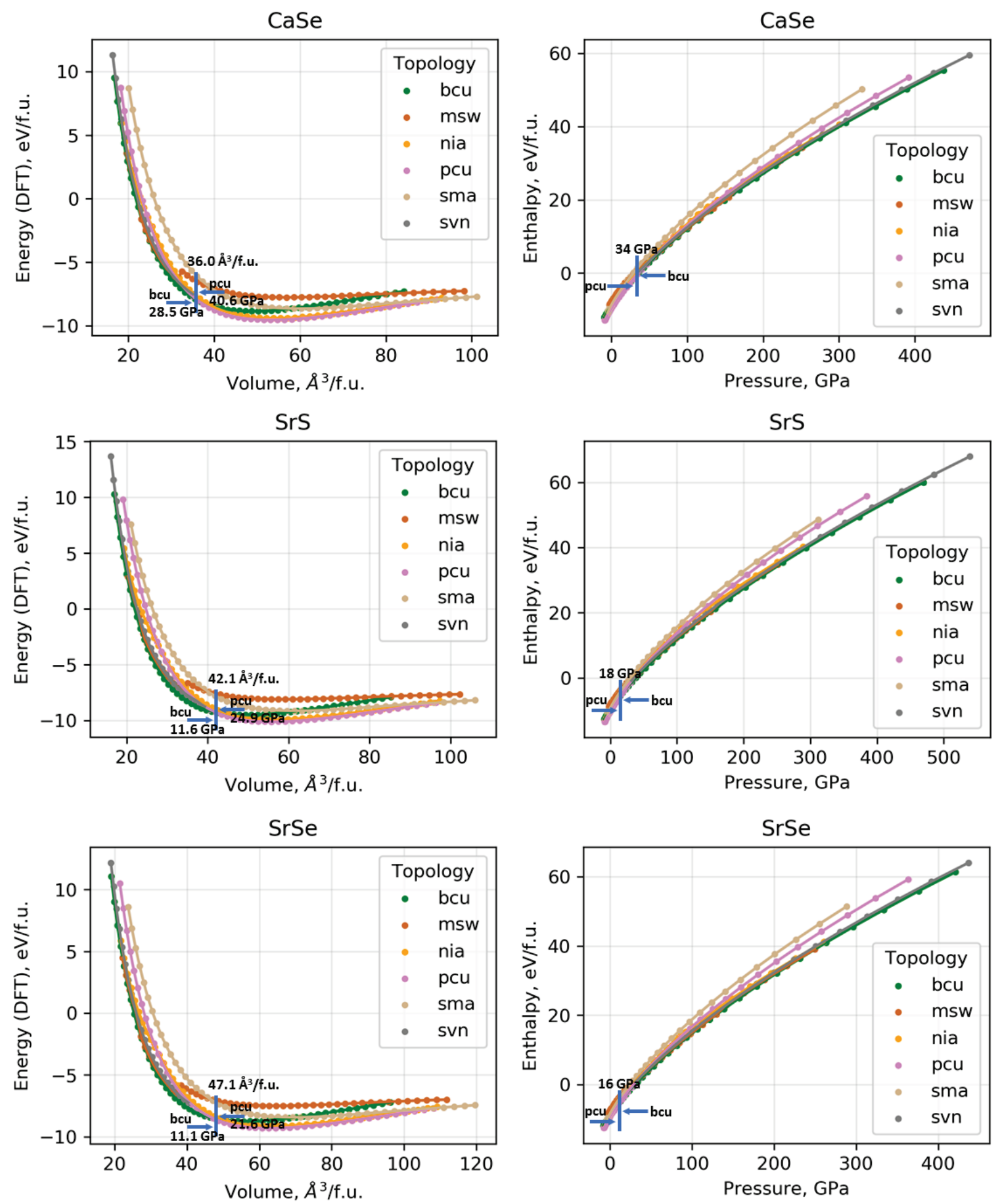

Figure S2 (continued). DFT-derived equations of state (left) and calculated dependencies of enthalpy on pressure (right) for the CaSe, SrS and SrSe phases. Parameters of phase transitions are given for both used protocols. The figure is continued on the next page. 
$\mathrm{BaS}$

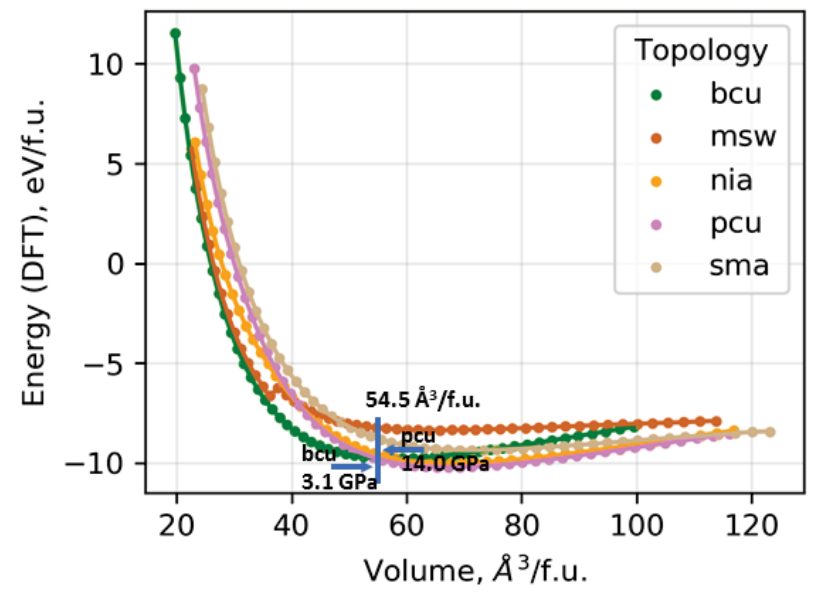

BaSe

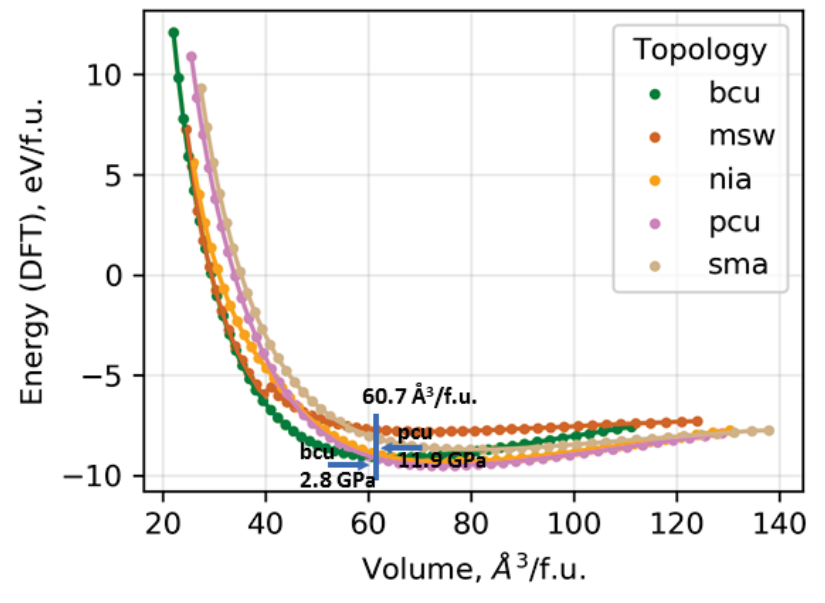

BaS

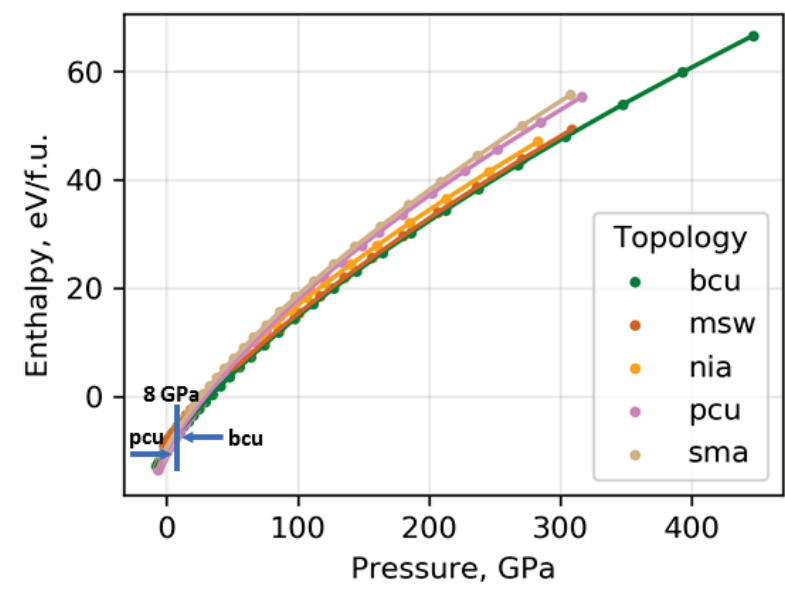

BaSe

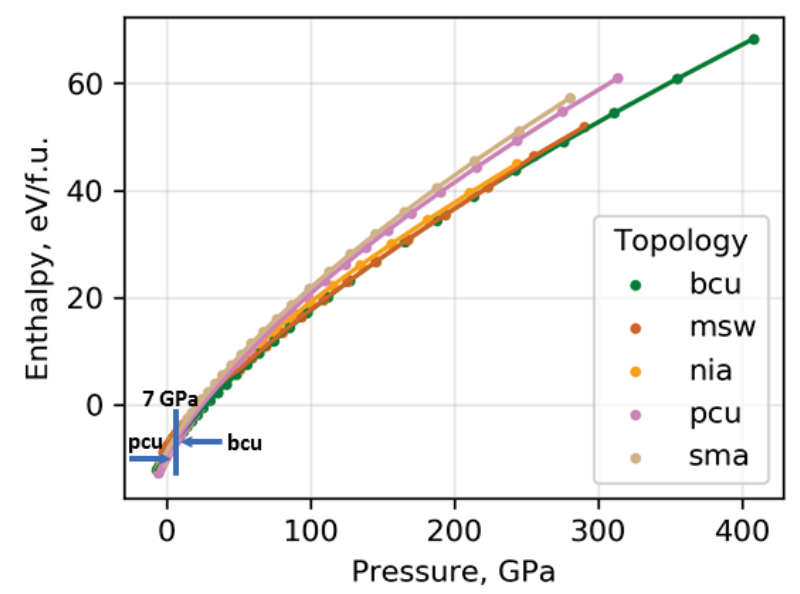

Figure S2 (continue). DFT-derived equations of state (left) and calculated dependencies of enthalpy on pressure (right) for the $\mathrm{BaS}$ and BaSe phases. Parameters of phase transitions are given for both used protocols.

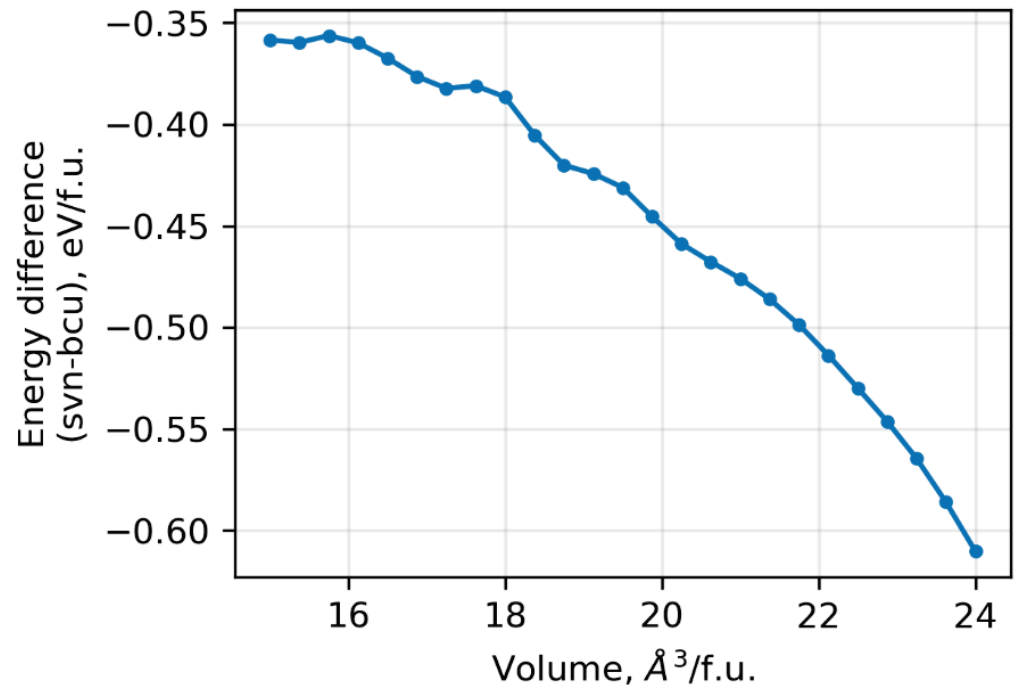

Figure S3. Characteristic dependency of energy difference between the MgSe-svn and MgSebcu phases obtained from the DFT-derived equations of state. 

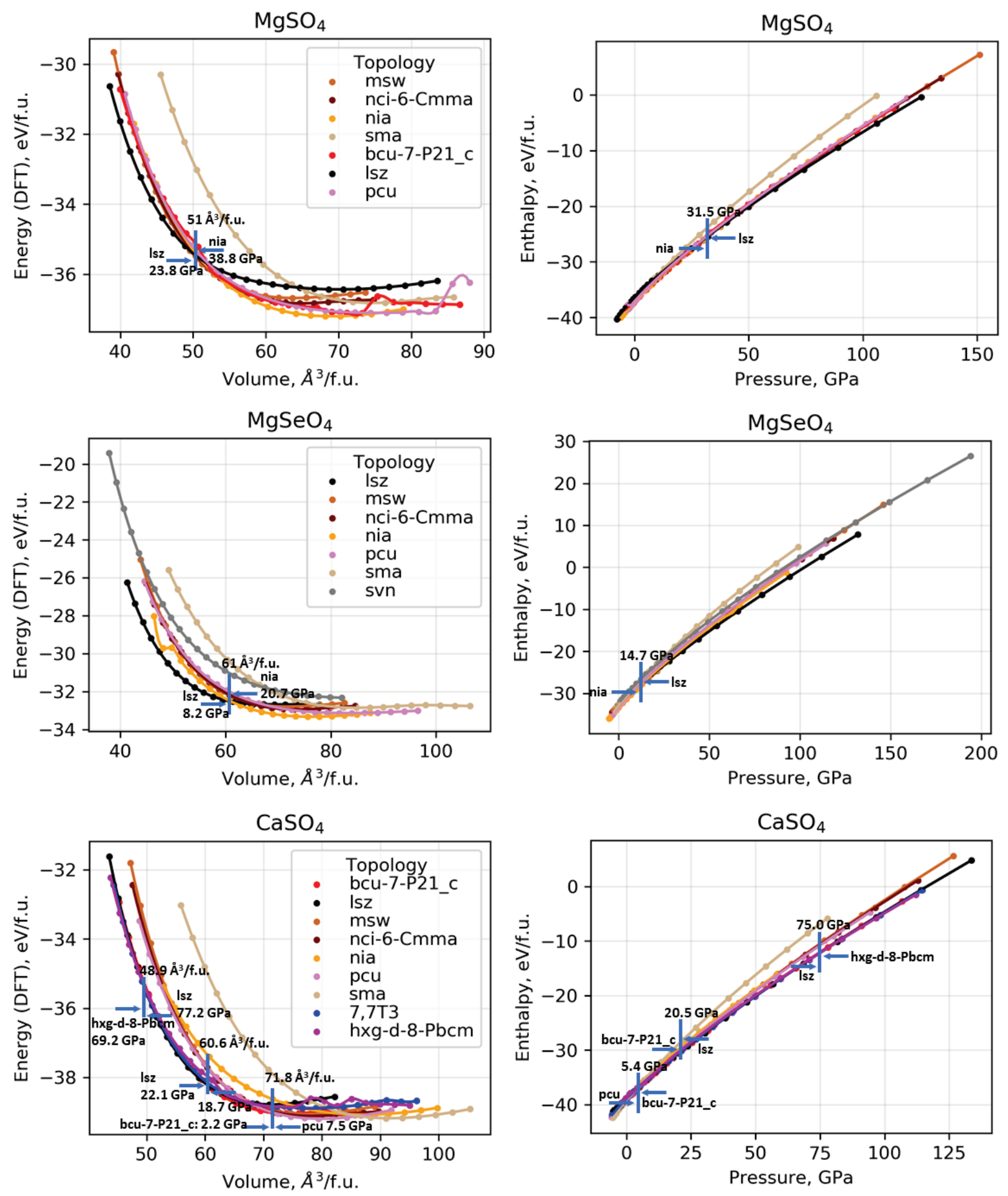

Figure S4. DFT-derived equations of state (left) and calculated dependencies of enthalpy on pressure (right) for the $\mathrm{MgSO}_{4}, \mathrm{MgSeO}_{4}$ and $\mathrm{CaSO}_{4}$ phases. Parameters of phase transitions are given for both used protocols. The figure is continued on the next page. 

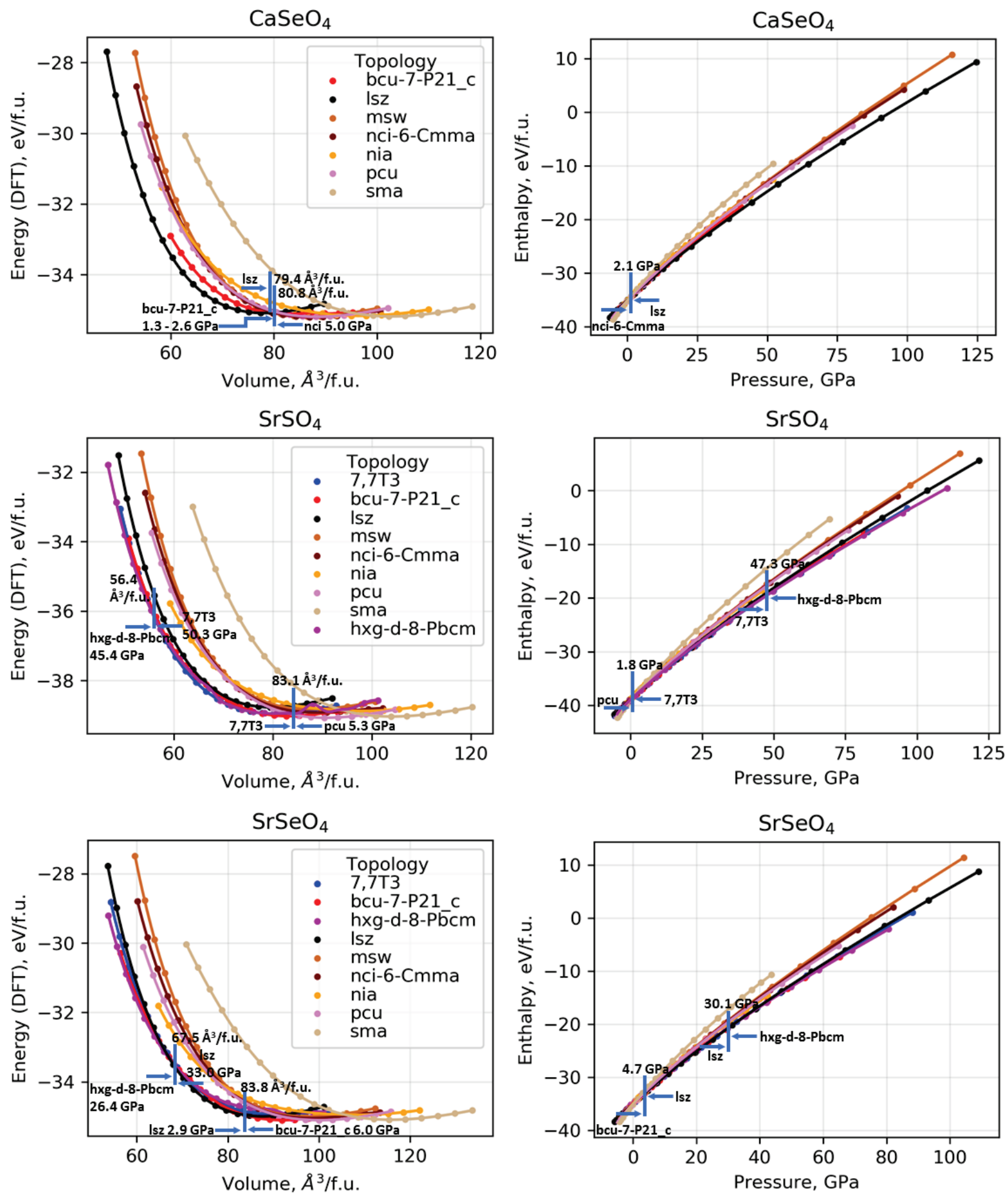

Figure S4 (continued). DFT-derived equations of state (left) and calculated dependencies of enthalpy on pressure (right) for the $\mathrm{CaSeO}_{4}, \mathrm{SrSO}_{4}$ and $\mathrm{SrSeO}_{4}$ phases. Parameters of phase transitions are given for both used protocols. The figure is continued on the next page. 

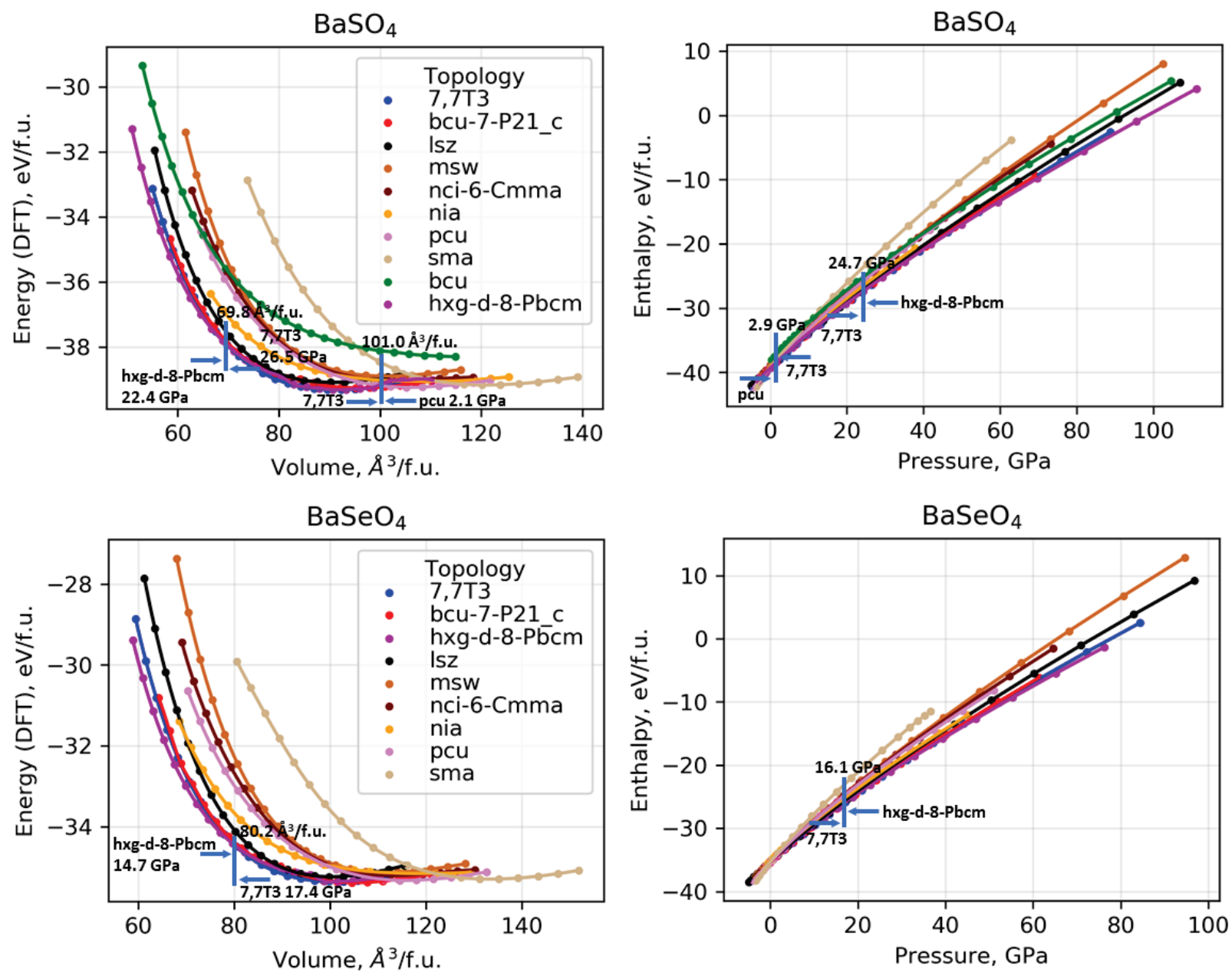

Figure S4 (continued). DFT-derived equations of state (left) and calculated dependencies of enthalpy on pressure (right) for the $\mathrm{BaSO}_{4}$ and $\mathrm{BaSeO}_{4}$ phases. Parameters of phase transitions are given for both used protocols. 


\section{Static and Dynamic Stability of the Potentially New Phases}

By using preoptimized crystal structures, we calculated static and dynamic stability for the potentially new $M\left(X_{\mathrm{O}_{4}}\right)$ phases. For static stability calculations, the protocol implemented in VASP [29] (IBRION=6) was used. We set 4 (NFREE) symmetrically inequivalent distortions (ionic displacements and variations of the model cell sizes and shape) of value of 0.007 (POTIM). Remaining parameters of the modeling were preserved (see the Computational Methods section).

For the structures possessing static stability within the ELATE [30] analyses of the obtained results, dynamic stability was checked by using the Phonopy package [31]. All unit cells with dimensions smaller than $8 \AA$ were replaced by the corresponding supercells in order to exclude self-interaction between the distorted atomic positions. For the same reason, the phonon calculations were performed at the $\Gamma$-point of the reciprocal space. A uniform $8 \times 8 \times 8$ grid in the reciprocal spaces was used to plot the phonon densities of states. For the structures possessing no negative phonon frequencies, the specific pathways in reciprocal space were obtained by using Aflow-online service [32] to plot the phonon band structures.

The obtained results on the mechanic stability are given in Table S5. For more details, the readers are referred to the Phonopy Reports and ELATE Reports sections below.

Table S5. Mechanical stability of the potentially new phases according to the DFT modeling results.

\begin{tabular}{|c|c|c|c|c|c|}
\hline Composition & Topology & $\begin{array}{l}\text { Pressure, } \\
\mathrm{GPa}\end{array}$ & $\begin{array}{l}\text { Static } \\
\text { stability }\end{array}$ & $\begin{array}{l}\text { No soft modes } \\
\text { at } \Gamma \text {-point }\end{array}$ & $\begin{array}{l}\text { Dynamic stability } \\
\text { (chosen supercell) }\end{array}$ \\
\hline \multirow{2}{*}{$\mathrm{MgSO}_{4}$} & msw & 24.6 & + & + & $-\left(\begin{array}{lll}2 & 2 & 2\end{array}\right)$ \\
\hline & Isz & 40.3 & + & + & $+\left(\begin{array}{lll}2 & 2 & 1\end{array}\right)$ \\
\hline $\mathrm{MgSeO}_{4}$ & Isz & 11.2 & + & + & $+\left(\begin{array}{lll}2 & 2 & 1\end{array}\right)$ \\
\hline \multirow{2}{*}{$\mathrm{SrSO}_{4}$} & bcu-7- $P 2_{1} / c$ & 2.1 & + & + & $-\left(\begin{array}{lll}2 & 2 & 2\end{array}\right)$ \\
\hline & hxg-d-8-Pbcm & 49.7 & + & + & $+\left(\begin{array}{ll}2 & 22\end{array}\right)$ \\
\hline \multirow{2}{*}{$\mathrm{SrSeO}_{4}$} & Isz & 25.1 & + & + & $+\left(\begin{array}{lll}2 & 2 & 1\end{array}\right)$ \\
\hline & hxg-d-8-Pbcm & 29.8 & + & + & $+\left(\begin{array}{ll}2 & 22\end{array}\right)$ \\
\hline $\mathrm{BaSeO}_{4}$ & hxg-d-8-Pbcm & 15.4 & + & + & $+\left(\begin{array}{lll}2 & 22 & 2\end{array}\right)$ \\
\hline $\mathrm{CaSO}_{4}$ & 7,7T3 & 70.8 & - & + & Not checked \\
\hline
\end{tabular}




\section{References}

[1] Sharma, H.; Sharma, V.; Huan T. D. Exploring $\mathrm{PtSO}_{4}$ and $\mathrm{PdSO}_{4}$ phases: an evolutionary algorithm based investigation. Phys. Chem. Chem. Phys. 2015, 17, 18146-151.

[2] Bear, I. J.; Mumme, W. G. The crystal chemistry of zirconium sulphates. VI. The structure of alpha-Zr( $\left(\mathrm{SO}_{4}\right)_{2}$. Acta Cryst. 1970, B26, 1140-1145.

[3] Senguttuvan, P.; Rousse, G.; Vezin, H.; Tarascon, J.-M.; Palacin, M. R. Titanium(III) sulfate as new negative electrode for sodium-ion batteries. Chem. Mater. 2013, 25, 2391-2393.

[4] Iskhakova, L. D.; Kozlova, N. P.; Marugin, V. V. Crystal structure of $\mathrm{Ce}\left(\mathrm{SeO}_{4}\right)_{2}$. Kristallografiya, 1990, 35, 1089-1093.

[5] Mercier, R.; Douglade, J.; Bernard, J. Structure cristalline de $\mathrm{Sb}_{2} \mathrm{O}_{3}\left(\mathrm{SO}_{3}\right)_{3}$. Acta Cryst. 1976, B32, 2787-2791.

[6] Subban, C. V.; Rousse, G.; Courty, M.; Barboux, P.; Tarascon, J.-M. Polymorphism in $\mathrm{Bi}_{2}\left(\mathrm{SO}_{4}\right)_{3}$. Solid State Sci. 2014, 38, 25-29.

[7] Weil, M. The high-temperature beta modification of iron(II) sulfate. Acta Cryst.: Struct. Rep. Online. 2007, E63, i192-i192.

[8] Fuess, H.; Will, G. Bestimmung der Kristallstruktur der Selenate $\mathrm{MSeO}_{4}(\mathrm{M}=\mathrm{Mn}, \mathrm{Co}, \mathrm{Ni})$ durch Roentgen- und Neutronenbeugung. Z. Anorg. Allg. Chem. 1968, 358, 125-137.

[9] Antao, S. M. The crystal structure of tin sulphate, $\mathrm{SnSO}_{4}$, and comparison with isostructural $\mathrm{SrSO}_{4}, \mathrm{PbSO}_{4}$, and $\mathrm{BaSO}_{4}$. Powder Diffr. 2012, 27, 179-183.

[10] Morozov, I. V.; Troyanov, S. I.; Stiewe, A.; Kemnitz, E. Synthesis and Crystal Structure of Selenates $\mathrm{Cd}\left(\mathrm{HSeO}_{4}\right)_{2}, \mathrm{CdSeO}_{4}$, and $\mathrm{Na}_{2} \mathrm{Se}_{2} \mathrm{O}_{7}$. Zh. Neorg. Khim. 1999, 44, 1536-1541.

[11] Spiess, M.; Gruehn, R. Zum Hoch temperature verhalten von $\mathrm{CdSO}_{4}$. Z. Anorg. Allg. Chem. 1979, 455, 16-28.

[12] Sawade, H.; Takeuchi, Y. Structures of the high-temperature form of the barite type compounds. alpha $\mathrm{BaSO}_{4}$. Z. Kristallogr. 1987, 181, 179-186.

[13] Hinrichsen, B.; Dinnebier, R. E.; Liu, H.; Jansen, M. The high pressure crystal structures of tin sulphate: a case study for maximal information recovery from 2D powder diffraction data. Z. Kristallogr. 2008, 223, 195-203.

[14] Crichton, W. A.; Parise, J. B.; Antao, S. M.; Grzechnik, A. Evidence for monazite-, barite-, and $\mathrm{AgMnO}_{4}$ (distorted barite)- type structures of $\mathrm{CaSO}_{4}$ at high pressure and temperature. Am. Mineral. 2005, 90, 22-27.

[15] Effenberger, H.; Pertlik, F. Four monazite type structures: comparison of $\mathrm{SrCrO}_{4}, \mathrm{SrSeO}_{4}$, $\mathrm{PbCrO}_{4}$ (crocoite), and $\mathrm{PbSeO}_{4}$. Z. Kristallogr. 1986, 176, 75-83.

[16] Lee, J.-S.; Wang, H.-R.; Iizuka, Y.; and Yu, S.-C. Crystal structure and Raman spectral studies of $\mathrm{BaSO}_{4}-\mathrm{PbSO}_{4}$ solid solution. Z. Kristallogr. 2005, 220, 1-9. 
[17] Andara, A.; Salvado, M. A.; Fernandez-Gonzalez, A.; Garcia-Granda, S.; Prieto, M. Crystal structure of barium selenate, $\mathrm{BaSeO}_{4}$. Z. Kristallogr. - New Cryst. Struct. 2005, 220, 5-6.

[18] Berthold, H. J.; Born, J.; Wartchow, R. The crystal structure of copper(I) sulfate $\mathrm{Cu}_{2} \mathrm{SO}_{4}$. The first structure of a simple cuprous oxosalt. Z. Kristallogr. 1988, 183, 309-318.

[19] Pertlik, F.; Fuith, A. H. Structure of dilithium selenate(VI). Acta Crystallogr. 1989, C45, $158-159$.

[20] Dorm, E. The crystal structure of mercury(I) sulfate and selenate. Acta Chem. Scand. 1969, $23,1607-1615$.

[21] Santamaria-Perez, D.; Chulia-Jordan, R. Compression of mineral barite, $\mathrm{BaSO}_{4}$ : a structural study. High pressure research. 2012, 32, 81-88.

[22] Mehrotra, B. N.; Hahn, T.; Eysel, W.; Roepke, H. Crystal chemistry of compounds with thenardite $\left(\mathrm{Na}_{2} \mathrm{SO}_{4} \mathrm{~V}\right)$ structure. Neu. JB. Mineral., Monatsh. 1978, 9, 408-421.

[23] Fukami, T.; Chen, R.-H. Refinement of crystal structure of $\mathrm{Na}_{2} \mathrm{SeO}_{4}$ at room temperature. J. Phys. Soc. Jpn. 2003, 72, 3299-3300.

[24] Parfitt, D. C.; Keen, D. A.; Hull, S.; Crichton, W. A.; Mezouar, M.; Wilson, M.; Madden, P. A. High-pressure forms of lithium sulphate: structural determination and computer simulation. Phys. Rev. B: Condens. Matter Mater. Phys. 2005, 72, 054121-1.

[25] Friese, K.; Goeta, A. E.; Leech, M. A.; Howard, J. A. K.; Madariaga, G.; Pérez-Mato, J. M.; Breczewski, T. The low-temperature structure of $\mathrm{Tl}_{2} \mathrm{SeO}_{4}$ at 30 K. J. Solid State Chem. 2004, 177, 1127-1136.

[26] Takahashi, I.; Onodera, A.; Shiozaki, Y. Structure of rubidium selenate at room temperature. Acta Crystallogr. 1987, C43, 179-182.

[27] Wallez, G.; Jaulmes, S.; Elfakir, A.; Souron, J. P.; Quarton, M. beta-Tl ${ }_{2} \mathrm{SO}_{4}$. Acta Crystallogr. 2004, C60, i107-i109.

[28] Gonzalez-Silgo, C.; Solans, X.; Ruiz-Perez, C.; Martinez-Sarrion, M. L.; Mestres, L. Study on $\mathrm{K}_{2} \mathrm{SeO}_{4}$ at different temperatures. Ferroelectr. 1996, 177, 191-199.

[29] Perdew, J. P.; Burke, K.; Ernzerhof, M. Generalized Gradient Approximation Made Simple. Phys. Rev. Lett. 1996, 77, 3865-3868.

[30] Gaillac, R., Pullumbi, P., Coudert, F. X. ELATE: an open-source online application for analysis and visualization of elastic tensors J. Phys. Condens. Matter, 2016, 28, 275201.

[31] Togo, A.; Tanaka, I. First principles phonon calculations in materials science. Scr. Mater. 2015, 108, 1-5.

[32] Setyawan, W., Curtarolo, S. High-throughput electronic band structure calculations: Challenges and tools. Comput. Mater. Sci. 2010, 49, 299-312. 


\section{Phonopy Reports}


$\mathrm{MgSO}_{4}$ - msw

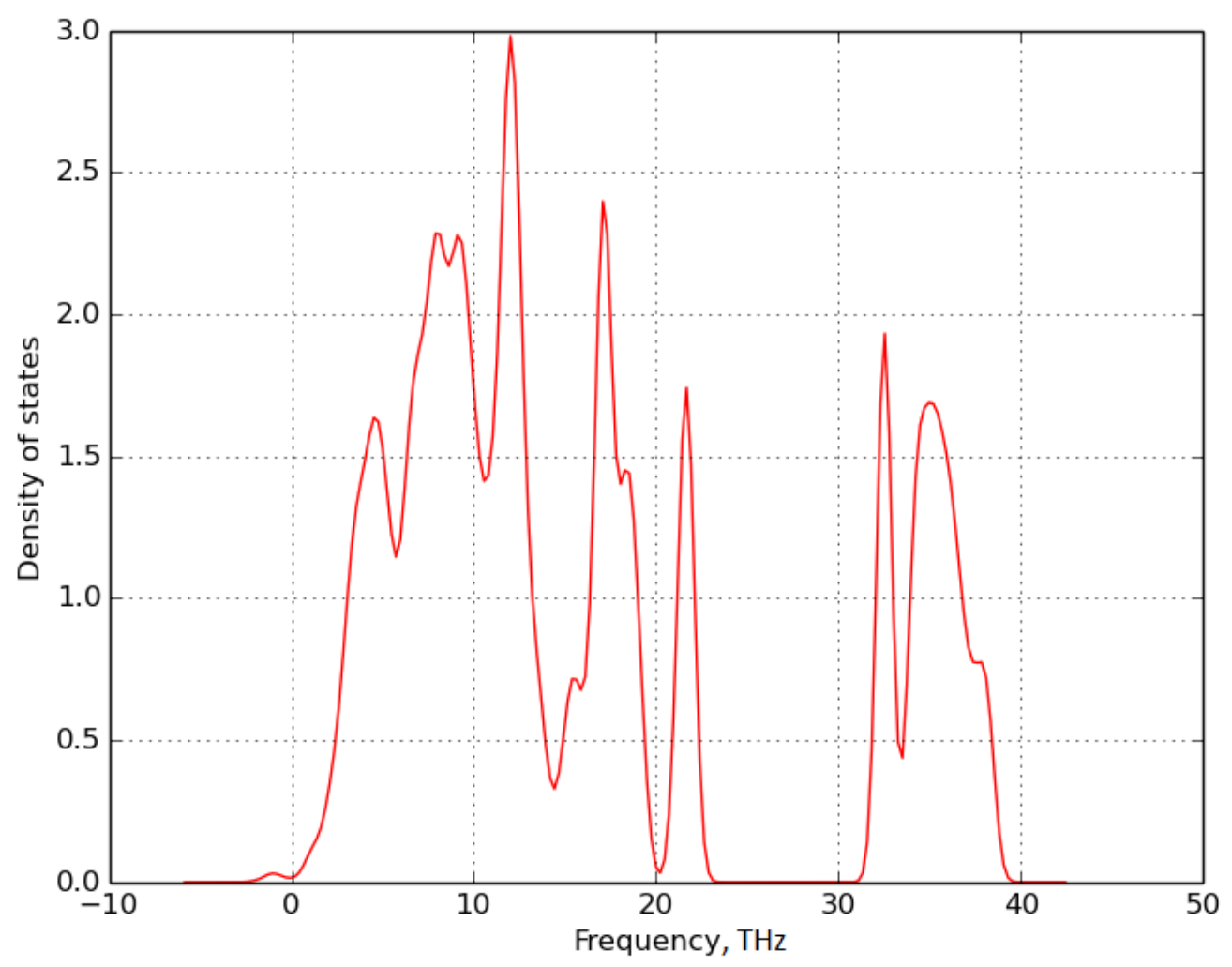




$$
\mathrm{MgSO}_{4} \text { - Isz }
$$
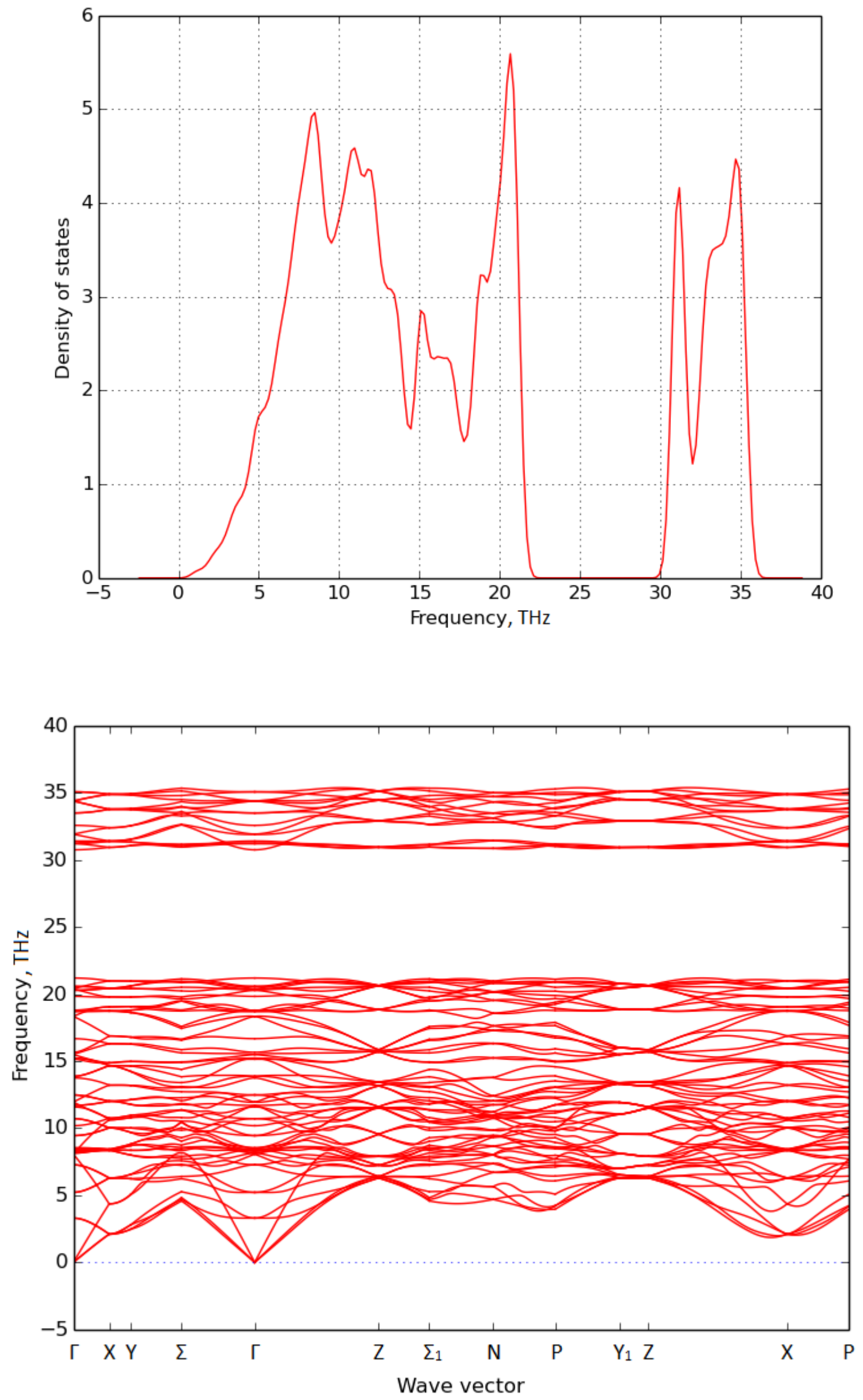


$$
\mathrm{MgSeO}_{4} \text { - Isz }
$$
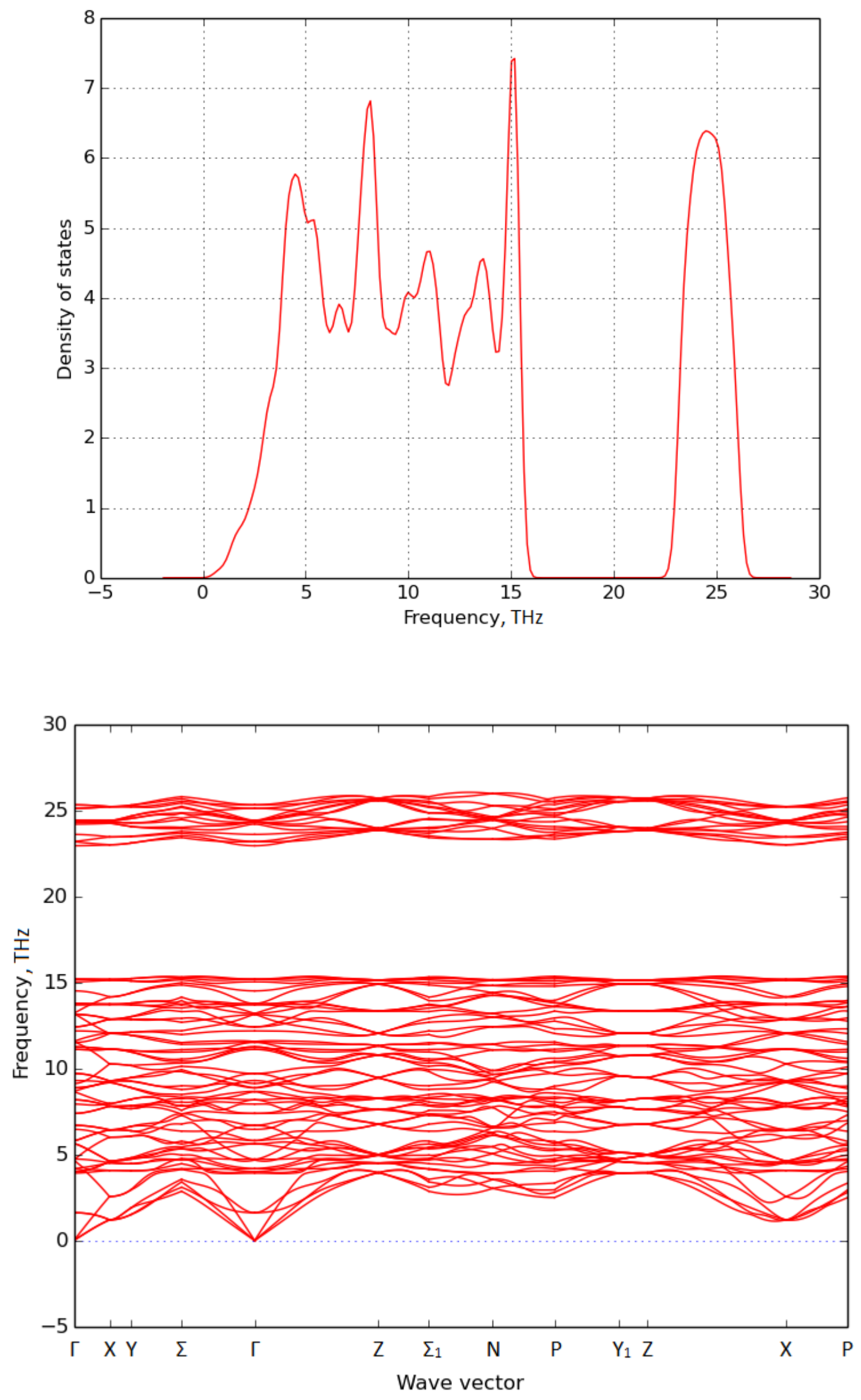
$\mathrm{SrSO}_{4}$ - bcu-7-P ${ }_{1} / c$

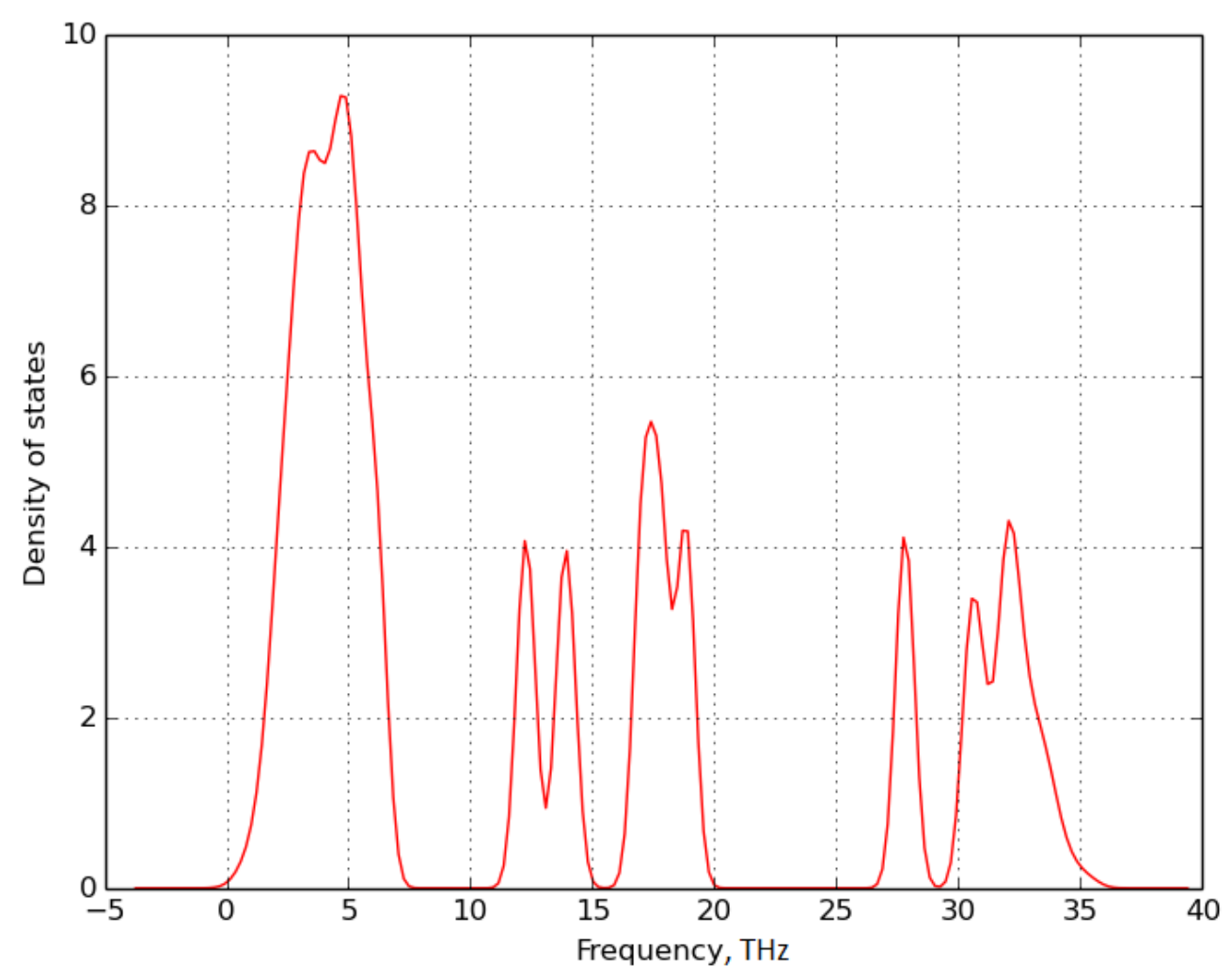




$$
\mathrm{SrSO}_{4} \text { - hxg-d-8-Pbcm }
$$
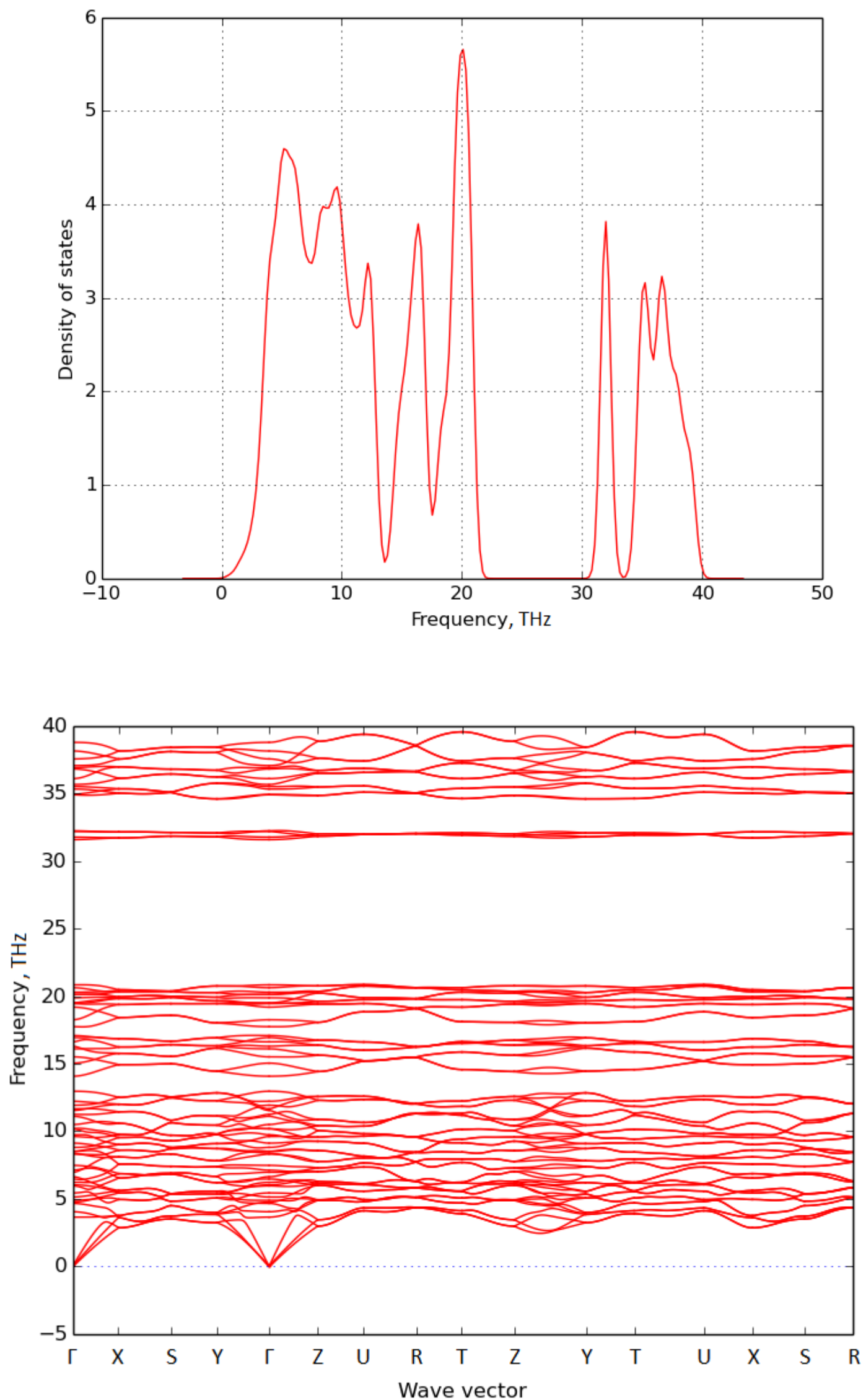


$$
\mathrm{SrSeO}_{4}-\mathbf{I s z}
$$
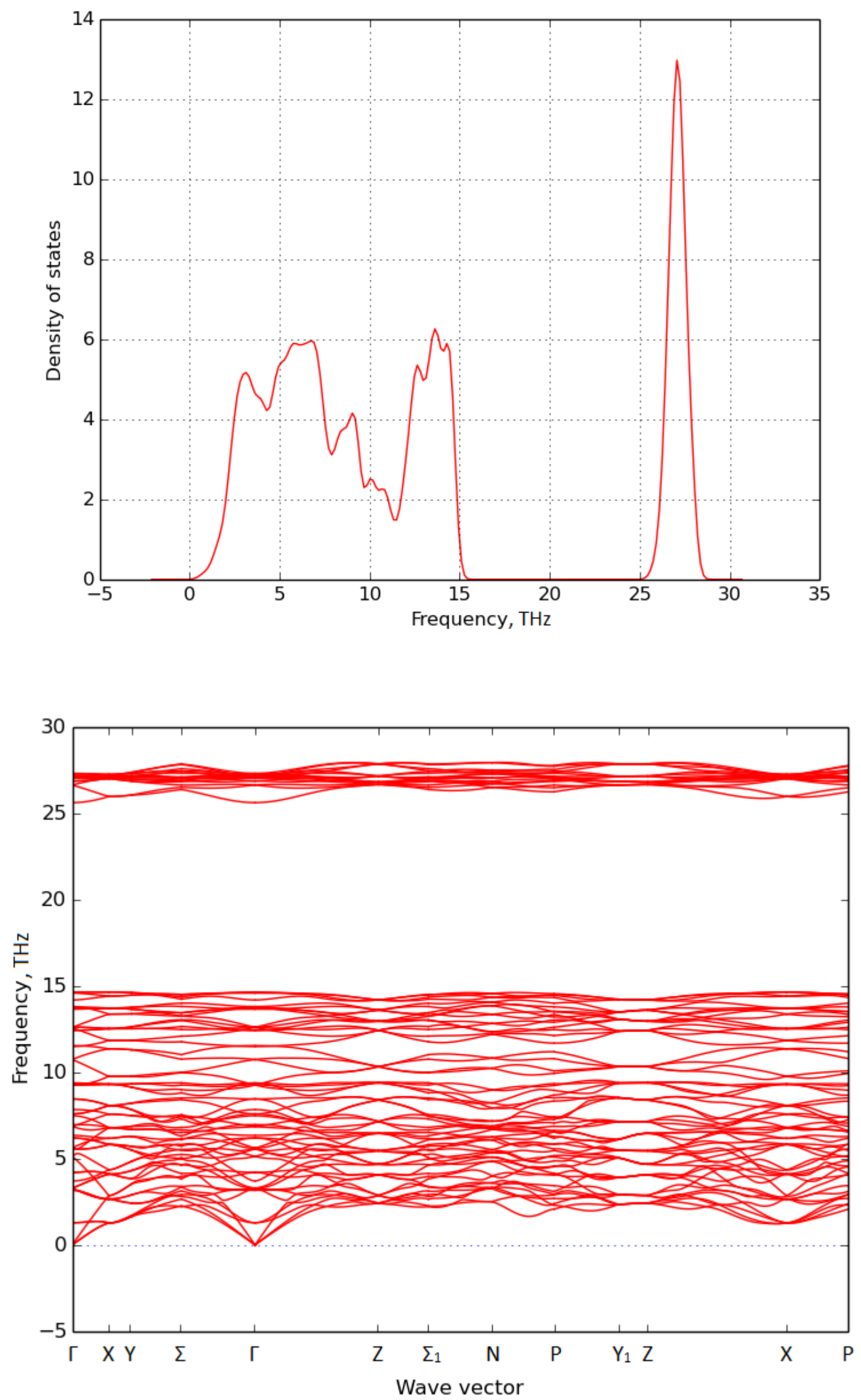
$\mathrm{SrSeO}_{4}$ - hxg-d-8-Pbcm
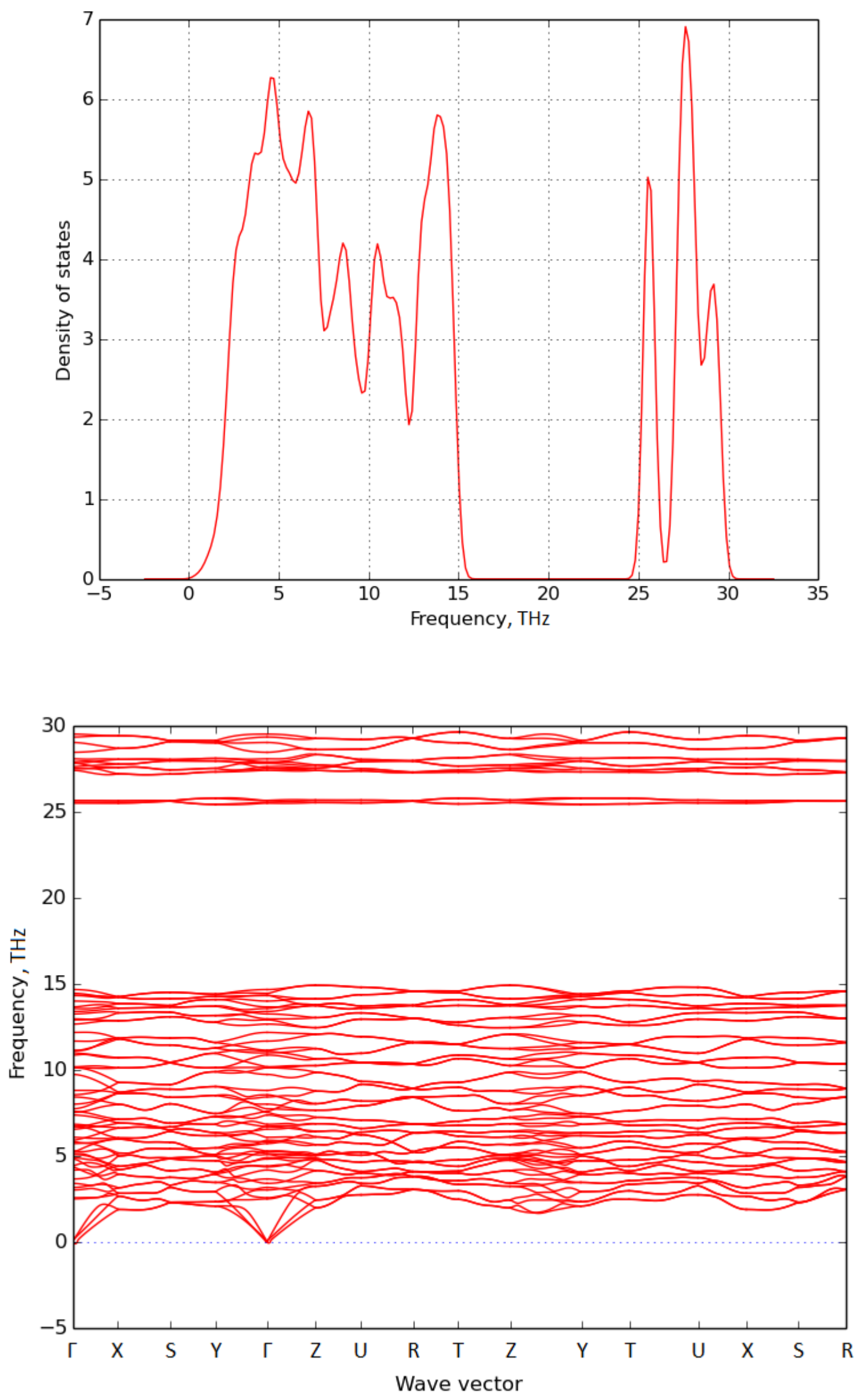


\section{$\mathrm{BaSeO}_{4}$ - hxg-d-8-Pbcm}
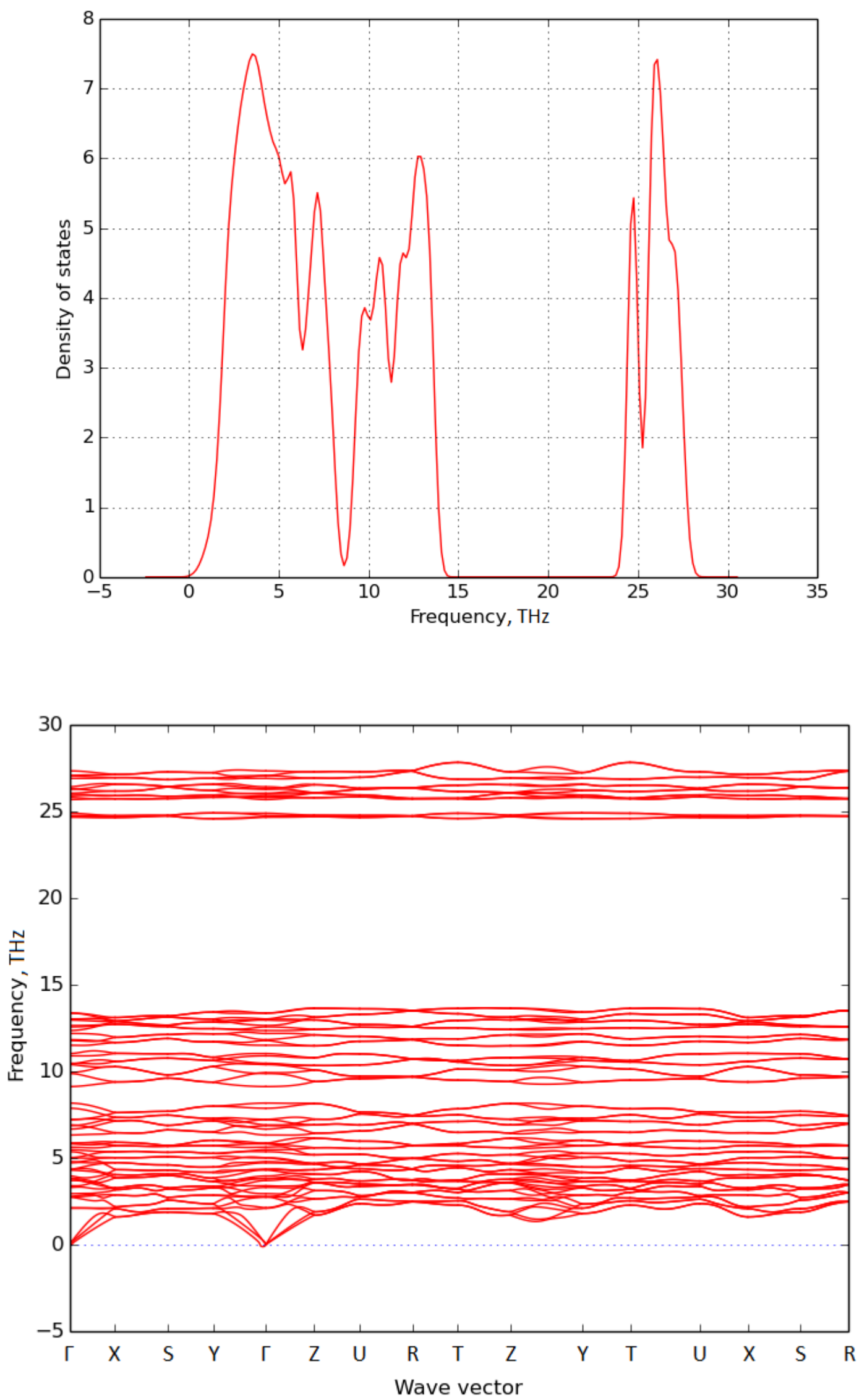


\section{ELATE Reports}




\section{ELATE: Elastic tensor analysis}

Welcome to ELATE, the online tool for analysis of elastic tensors, developed by Romain Gaillac and FrançoisXavier Coudert at CNRS / Chimie ParisTech.

If you use the software in published results (paper, conference, etc.), please cite the corresponding_paper ( $J$.

Phys. Condens. Matter, 2016, 28, 275201) and give the website URL.

ELATE is open source software. Any queries or comments are welcome at fx.coudert@chimie-paristech.fr

\section{Summary of the properties}

Input: stiffness matrix (coefficients in GPa) of MgSO4-msw (24.649 GPa)

$\begin{array}{rrrrrr}273.45 & 155.87 & 129.86 & -14.845 & -15.048 & -27.065 \\ 155.87 & 276.97 & 115.11 & 21.037 & 37.017 & 2.2675 \\ 129.86 & 115.11 & 329.07 & -26.599 & 7.3293 & -7.8321 \\ -14.845 & 21.037 & -26.599 & 119.4 & 1.7009 & -16.144 \\ -15.048 & 37.017 & 7.3293 & 1.7009 & 82.969 & -25.591 \\ -27.065 & 2.2675 & -7.8321 & -16.144 & -25.591 & 96.566\end{array}$

\section{Average properties}

\begin{tabular}{|c|c|c|c|c|c|}
\hline Averaging scheme & Bulk modulus & Young's modulus & Shear modulus & Poisson's ratio \\
\hline Voigt & $K_{\mathrm{V}}=186.8 \mathrm{GPa}$ & $E_{\mathrm{V}}=236.41 \mathrm{GPa}$ & $\mathrm{G}_{\mathrm{V}}=91.697 \mathrm{GPa}$ & $v_{\mathrm{V}}=0.28907$ \\
\hline Reuss & $K_{\mathrm{R}}=184.2 \mathrm{GPa}$ & $E_{\mathrm{R}}=179.7 \mathrm{GPa}$ & $\mathrm{G}_{\mathrm{R}}=67.183 \mathrm{GPa}$ & $v_{\mathrm{R}}=0.3374$ \\
\hline Hill & $K_{\mathrm{H}}=185.5 \mathrm{GPa}$ & $E_{\mathrm{H}}=208.55 \mathrm{GPa}$ & $\mathrm{G}_{\mathrm{H}}=79.44 \mathrm{GPa}$ & $v_{\mathrm{H}}=0.31262$ \\
\hline
\end{tabular}

Eigenvalues of the stiffness matrix

\begin{tabular}{|c|c|c|c|c|c|}
\hline $\boldsymbol{\lambda}_{\mathbf{1}}$ & $\boldsymbol{\lambda}_{\mathbf{2}}$ & $\boldsymbol{\lambda}_{\mathbf{3}}$ & $\boldsymbol{\lambda}_{\mathbf{4}}$ & $\boldsymbol{\lambda}_{\mathbf{5}}$ & $\boldsymbol{\lambda}_{\mathbf{6}}$ \\
\hline $36.227 \mathrm{GPa}$ & $101.11 \mathrm{GPa}$ & $119.74 \mathrm{GPa}$ & $148.47 \mathrm{GPa}$ & $210.45 \mathrm{GPa}$ & $562.43 \mathrm{GPa}$ \\
\hline
\end{tabular}

Variations of the elastic moduli

\begin{tabular}{|c|c|c|c|c|c|c|c|c|c|}
\hline & \multicolumn{2}{|c|}{$\begin{array}{l}\text { Young's } \\
\text { modulus }\end{array}$} & \multicolumn{2}{|c|}{$\begin{array}{c}\text { Linear } \\
\text { compressibility }\end{array}$} & \multicolumn{2}{|c|}{ Shear modulus } & \multicolumn{2}{|c|}{ Poisson's ratio } & \\
\hline & $E_{\min }$ & $E_{\max }$ & $\boldsymbol{\beta}_{\min }$ & $\beta_{\max }$ & $\boldsymbol{G}_{\min }$ & $G_{\max }$ & $\mathbf{v}_{\min }$ & $\mathbf{v}_{\max }$ & \\
\hline Value & $\begin{array}{c}84.852 \\
\mathrm{GPa}\end{array}$ & $\begin{array}{c}296.47 \\
\mathrm{GPa}\end{array}$ & $\begin{array}{c}1.326 \\
\mathrm{TPa}^{-1}\end{array}$ & $\begin{array}{l}2.1267 \\
\mathrm{TPa}^{-1}\end{array}$ & $\begin{array}{c}29.076 \\
\mathrm{GPa}\end{array}$ & $\begin{array}{c}139.04 \\
\mathrm{GPa}\end{array}$ & -0.35822 & 0.94254 & Value \\
\hline Anisotropy & \multicolumn{2}{|c|}{3.494} & \multicolumn{2}{|c|}{1.6038} & \multicolumn{2}{|c|}{4.782} & \multicolumn{2}{|c|}{$\infty$} & Anisotropy \\
\hline Axis & $\begin{array}{l}0.8641 \\
0.2441 \\
0.4401\end{array}$ & $\begin{array}{c}-0.3058 \\
0.4089 \\
-0.8598\end{array}$ & $\begin{array}{c}-0.6352 \\
0.4287 \\
-0.6424\end{array}$ & $\begin{array}{r}0.6271 \\
0.7718 \\
-0.1050\end{array}$ & $\begin{array}{l}0.4660 \\
0.8539 \\
0.2316\end{array}$ & $\begin{array}{c}0.1695 \\
0.9644 \\
-0.2031\end{array}$ & $\begin{array}{r}0.3269 \\
0.4905 \\
-0.8078\end{array}$ & $\begin{array}{c}-0.4249 \\
0.8213 \\
0.3807\end{array}$ & Axis \\
\hline
\end{tabular}




\begin{tabular}{|c|c|c|c|c|}
\hline-0.7499 & -0.3011 & -0.3766 & -0.8535 & Second \\
\hline 0.5202 & 0.2469 & 0.8516 & -0.2231 & axis \\
\hline-0.4088 & 0.9210 & 0.3646 & -0.4710 &
\end{tabular}

\section{Spatial dependence of Young's modulus}

\section{Visualize in 3D}

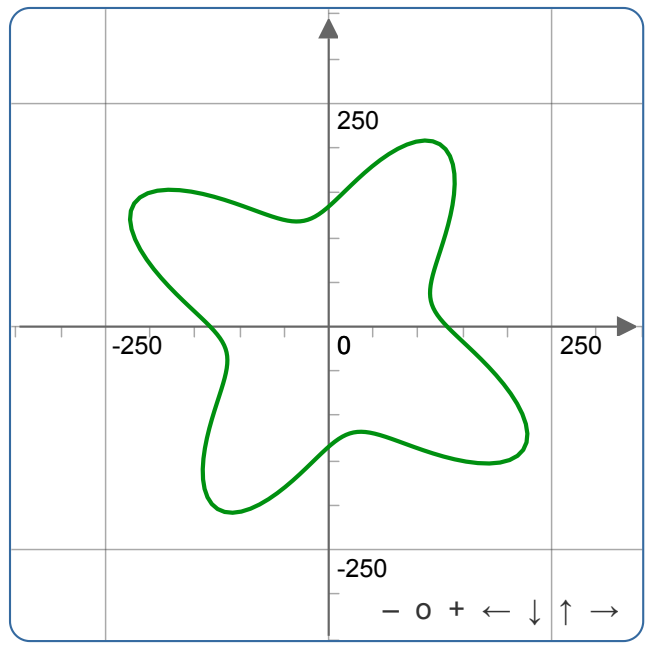

Young's modulus in (xy) plane

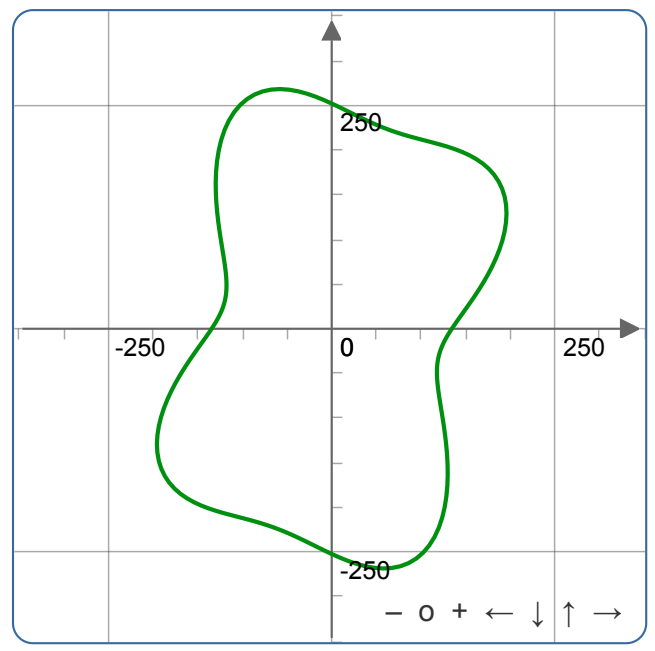

Young's modulus in (yz) plane

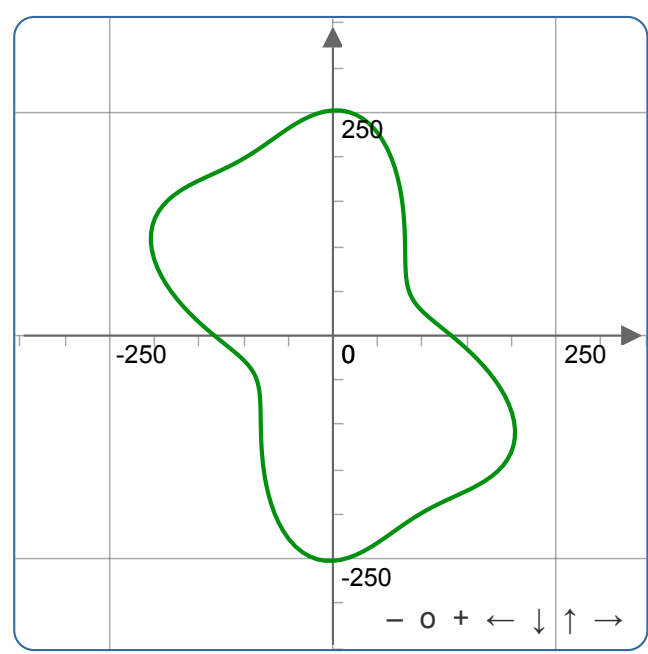

Young's modulus in (xz) plane

\section{Spatial dependence of linear compressibility}

\section{Visualize in 3D}




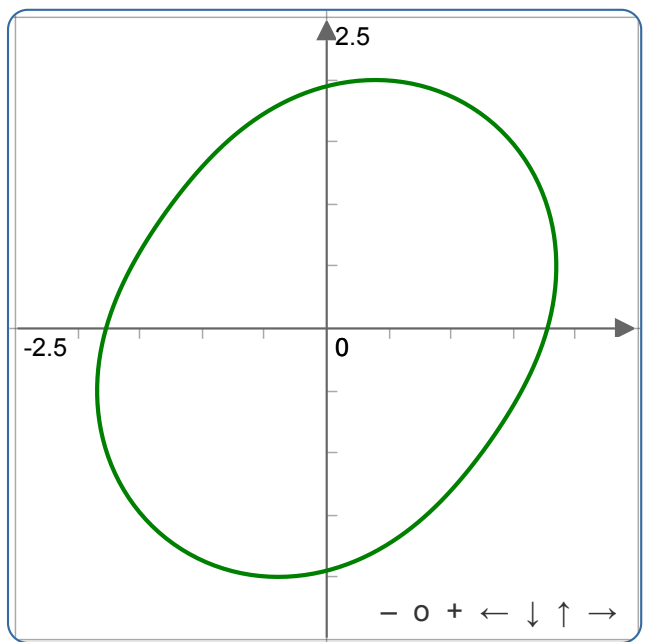

linear compressibility in (xy) plane

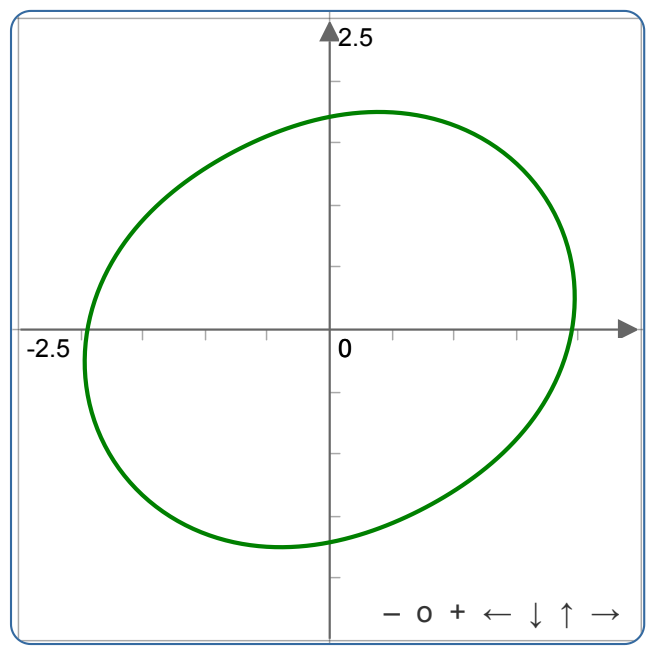

linear compressibility in (yz) plane

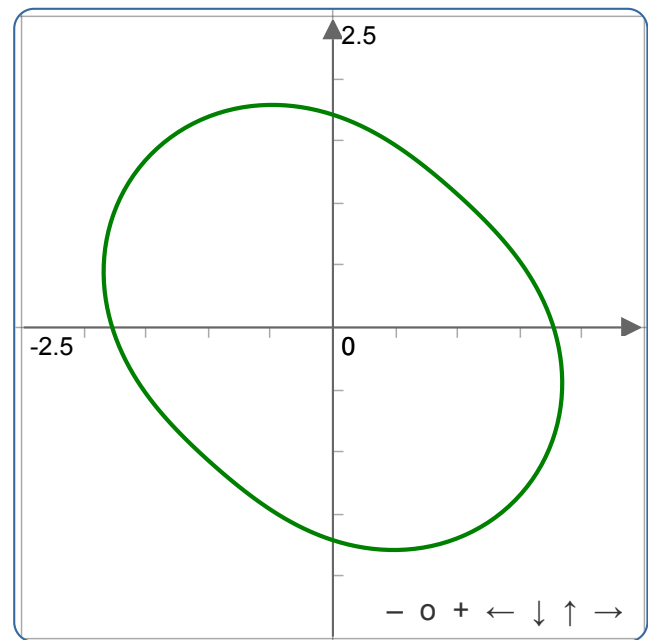

linear compressibility in (xz) plane

\section{Spatial dependence of shear modulus}

\section{Visualize in 3D}




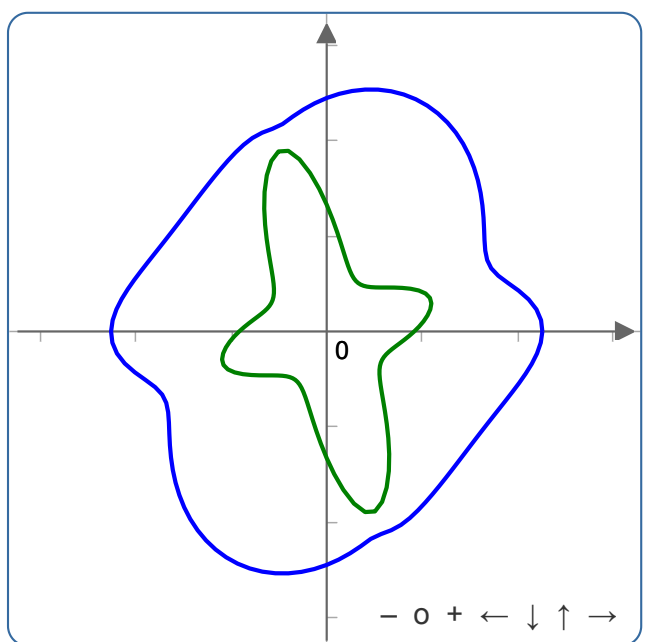

Shear modulus in (xy) plane

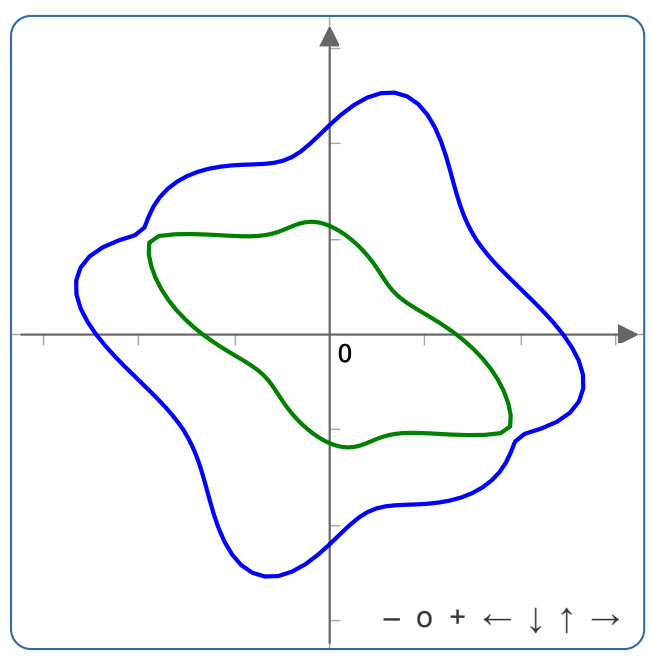

Shear modulus in (yz) plane

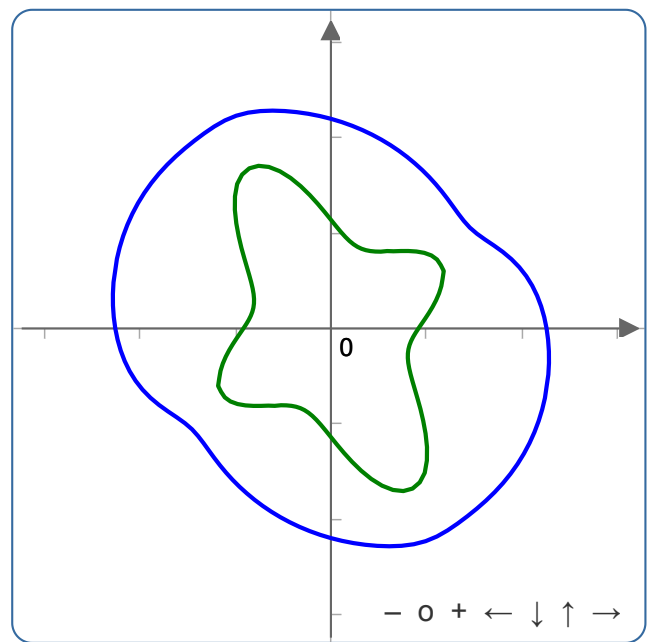

Shear modulus in (xz) plane

\section{Spatial dependence of Poisson's ratio}

\section{Visualize in 3D}




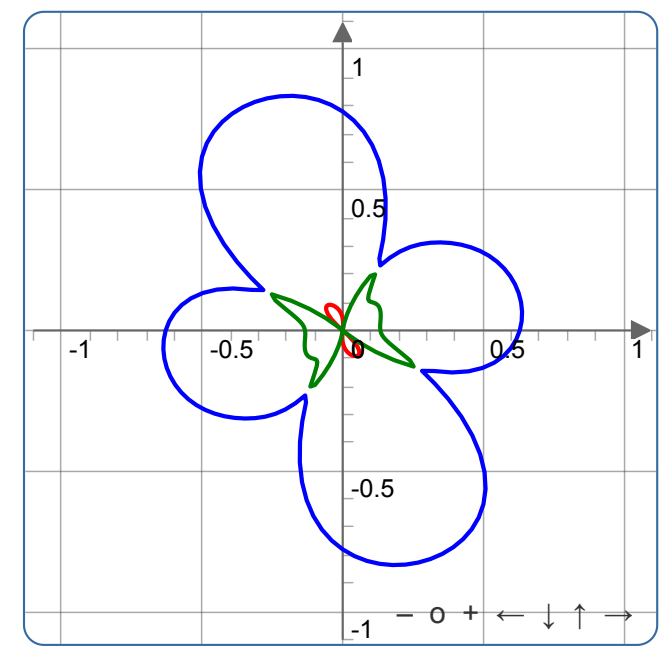

Poisson's ratio in (xy) plane

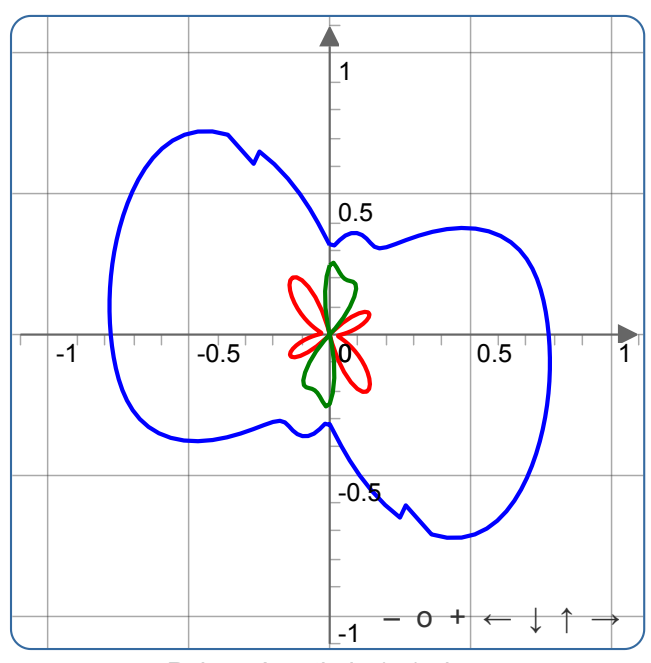

Poisson's ratio in (yz) plane

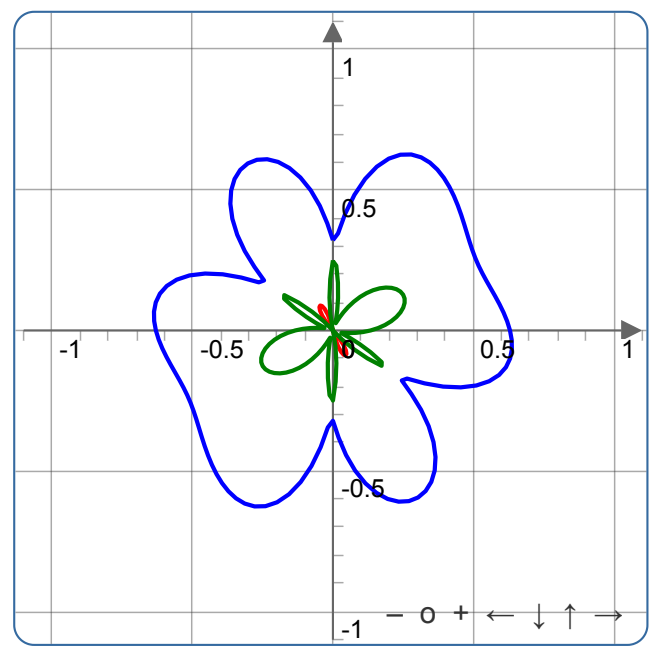

Poisson's ratio in (xz) plane

Code version: 2019.01.09 (running on Python 3.7.2) Execution time: 3.490 seconds 


\section{ELATE: Elastic tensor analysis}

Welcome to ELATE, the online tool for analysis of elastic tensors, developed by Romain Gaillac and François-Xavier Coudert at CNRS / Chimie ParisTech.

If you use the software in published results (paper, conference, etc.), please cite the corresponding_paper ( $J$. Phys. Condens. Matter, 2016, 28, 275201) and give the website URL.

ELATE is open source software. Any queries or comments are welcome at fx.coudert@chimie-paristech.fr

\section{Summary of the properties}

Input: stiffness matrix (coefficients in GPa) of MgSO4-Isz (40.328 GPa)

$\begin{array}{rrrrrr}430.11 & 164.9 & 165.95 & -30.401 & 0 & 0 \\ 164.9 & 430.11 & 165.95 & 30.401 & 0 & 0 \\ 165.95 & 165.95 & 284.95 & 0 & 0 & 0 \\ -30.401 & 30.401 & 0 & 141.71 & 0 & 0 \\ 0 & 0 & 0 & 0 & 87.269 & 1 \mathrm{e}-05 \\ 0 & 0 & 0 & 0 & 1 \mathrm{e}-05 & 87.269\end{array}$

\section{Average properties}

\begin{tabular}{|c|c|c|c|c|}
\hline $\begin{array}{c}\text { Averaging } \\
\text { scheme }\end{array}$ & Bulk modulus & $\begin{array}{c}\text { Young's } \\
\text { modulus }\end{array}$ & Shear modulus & Poisson's ratio \\
\hline Voigt & $\begin{array}{c}K_{\mathrm{V}}=237.64 \\
\mathrm{GPa}\end{array}$ & $E_{\mathrm{V}}=277.92 \mathrm{GPa}$ & $G_{\mathrm{V}}=106.47 \mathrm{GPa}$ & $v_{\mathrm{V}}=0.30509$ \\
\hline Reuss & $\begin{array}{c}K_{\mathrm{R}}=228.43 \\
\mathrm{GPa}\end{array}$ & $E_{\mathrm{R}}=258.52 \mathrm{GPa}$ & $\mathrm{G}_{\mathrm{R}}=98.568 \mathrm{GPa}$ & $v_{\mathrm{R}}=0.31138$ \\
\hline Hill & $\begin{array}{c}K_{\mathrm{H}}=233.04 \\
\mathrm{GPa}\end{array}$ & $E_{\mathrm{H}}=268.23 \mathrm{GPa}$ & $\mathrm{G}_{\mathrm{H}}=102.52 \mathrm{GPa}$ & $v_{\mathrm{H}}=0.30816$ \\
\hline
\end{tabular}

Eigenvalues of the stiffness matrix

\begin{tabular}{|c|c|c|c|c|c|}
\hline$\lambda_{1}$ & $\lambda_{\mathbf{2}}$ & $\boldsymbol{\lambda}_{\mathbf{3}}$ & $\boldsymbol{\lambda}_{\mathbf{4}}$ & $\boldsymbol{\lambda}_{\mathbf{5}}$ & $\boldsymbol{\lambda}_{\mathbf{6}}$ \\
\hline $87.269 \mathrm{GPa}$ & $87.269 \mathrm{GPa}$ & $128.21 \mathrm{GPa}$ & $158.71 \mathrm{GPa}$ & $278.71 \mathrm{GPa}$ & $721.25 \mathrm{GPa}$ \\
\hline
\end{tabular}

Variations of the elastic moduli

\begin{tabular}{|c|c|c|c|c|c|c|c|c|c|}
\hline & \multicolumn{2}{|c|}{$\begin{array}{l}\text { Young's } \\
\text { modulus }\end{array}$} & \multicolumn{2}{|c|}{$\begin{array}{l}\text { Linear } \\
\text { compressibility }\end{array}$} & \multicolumn{2}{|c|}{ Shear modulus } & \multicolumn{2}{|c|}{ Poisson's ratio } & \\
\hline & $E_{\min }$ & $E_{\max }$ & $\beta_{\min }$ & $\beta_{\max }$ & $G_{\min }$ & $G_{\max }$ & $v_{\min }$ & $\mathbf{v}_{\max }$ & \\
\hline Value & $\begin{array}{c}192.39 \\
\mathrm{GPa}\end{array}$ & $\begin{array}{c}410.56 \\
\mathrm{GPa}\end{array}$ & $\begin{array}{l}1.0396 \\
\mathrm{TPa}^{-1}\end{array}$ & $\begin{array}{l}2.2985 \\
\mathrm{TPa}^{-1}\end{array}$ & $\begin{array}{c}81.923 \\
\mathrm{GPa}\end{array}$ & $\begin{array}{c}148.08 \\
\mathrm{GPa}\end{array}$ & 0.1113 & 0.51077 & Value \\
\hline nisotropy & \multicolumn{2}{|c|}{2.134} & \multicolumn{2}{|c|}{2.2110} & \multicolumn{2}{|c|}{1.808} & \multicolumn{2}{|c|}{4.5893} & Anisotropy \\
\hline
\end{tabular}




\begin{tabular}{|c|c|c|c|c|c|c|c|c|c|}
\hline Axis & $\begin{array}{l}0.0000 \\
0.0000 \\
1.0000\end{array}$ & $\begin{array}{l}0.0000 \\
0.8668 \\
0.4986\end{array}$ & $\begin{array}{r}1.0000 \\
0.0000 \\
-0.0000\end{array}$ & $\begin{array}{l}0.0000 \\
0.0000 \\
1.0000\end{array}$ & $\begin{array}{l}0.4998 \\
0.5001 \\
0.7071\end{array}$ & $\begin{array}{l}0.7071 \\
0.6219 \\
0.3366\end{array}$ & $\begin{array}{c}-0.2626 \\
0.5815 \\
-0.7700\end{array}$ & $\begin{array}{r}1.0000 \\
-0.0007 \\
0.0008\end{array}$ & Axis \\
\hline & & & & & $\begin{array}{r}0.5001 \\
0.4999 \\
-0.7071\end{array}$ & $\begin{array}{r}-0.7071 \\
0.6219 \\
0.3365\end{array}$ & $\begin{array}{c}0.0899 \\
-0.7797 \\
-0.6196\end{array}$ & $\begin{array}{r}0.0010 \\
0.4233 \\
-0.9060\end{array}$ & $\begin{array}{l}\text { Second } \\
\text { axis }\end{array}$ \\
\hline
\end{tabular}

\section{Spatial dependence of Young's modulus}

\section{Visualize in 3D}

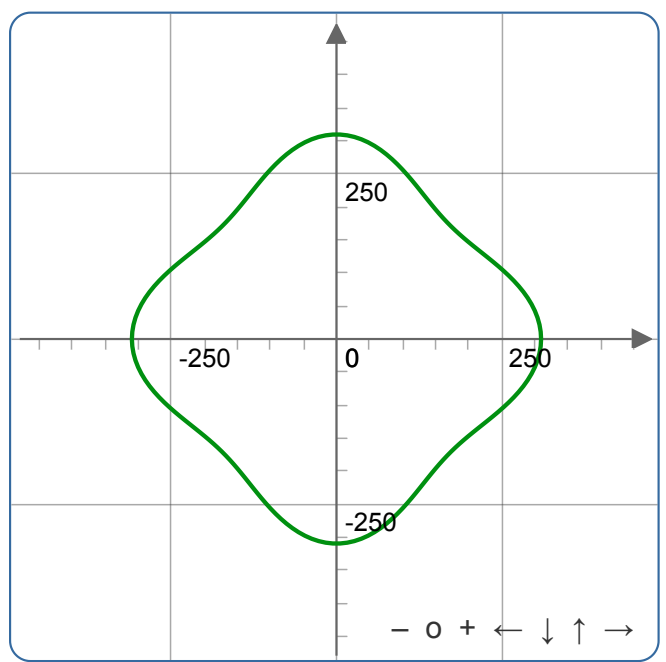

Young's modulus in (xy) plane

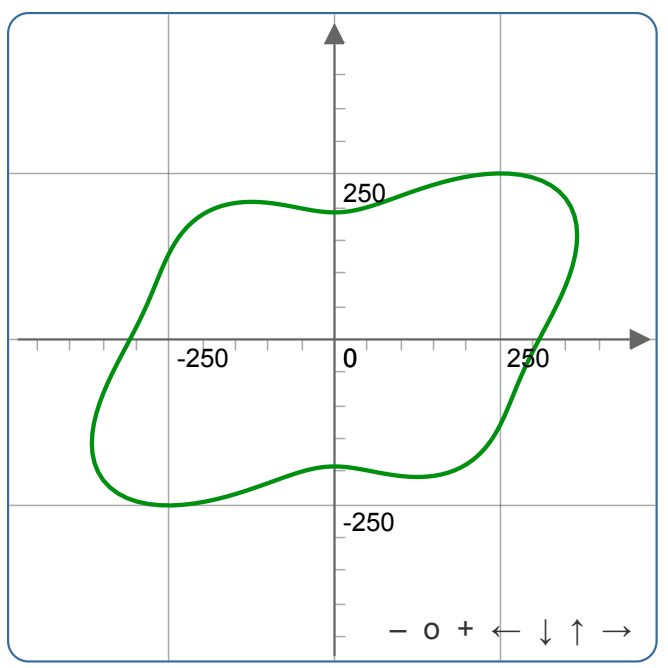

Young's modulus in (yz) plane

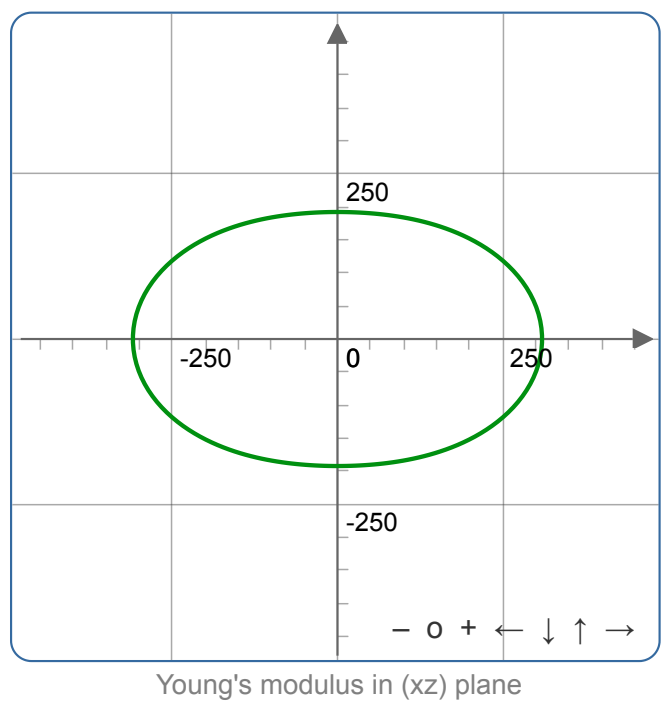

Young's modulus in (xz) plane

\section{Spatial dependence of linear compressibility}




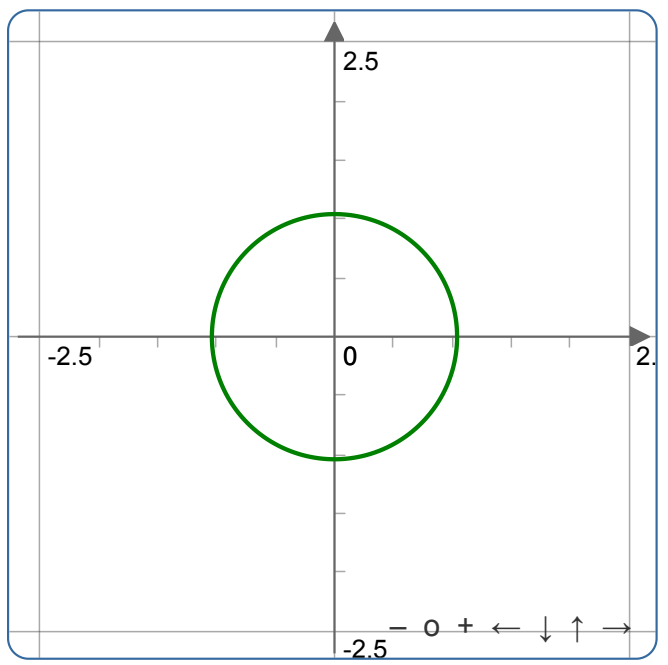

linear compressibility in (xy) plane

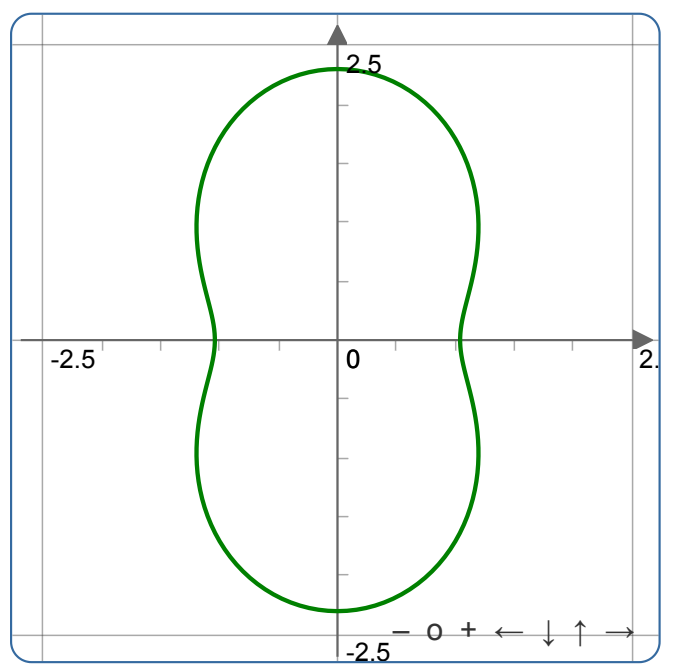

linear compressibility in (yz) plane

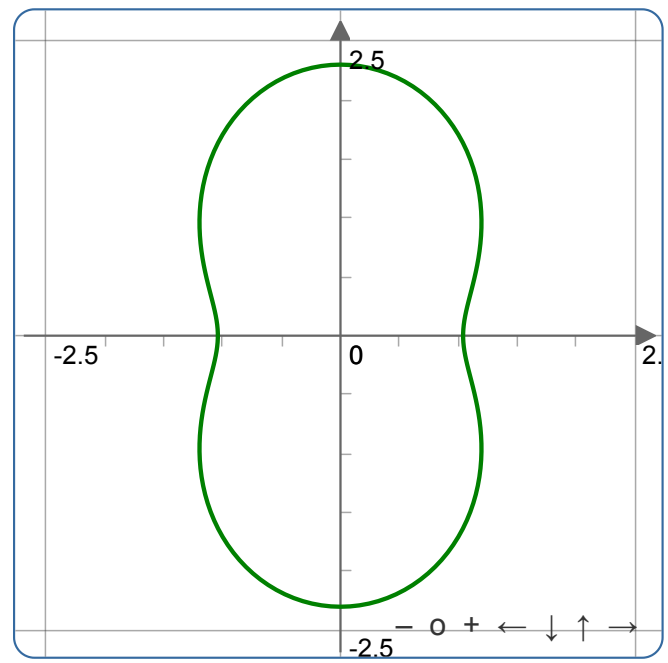

linear compressibility in (xz) plane

\section{Spatial dependence of shear modulus}

Visualize in 3D 


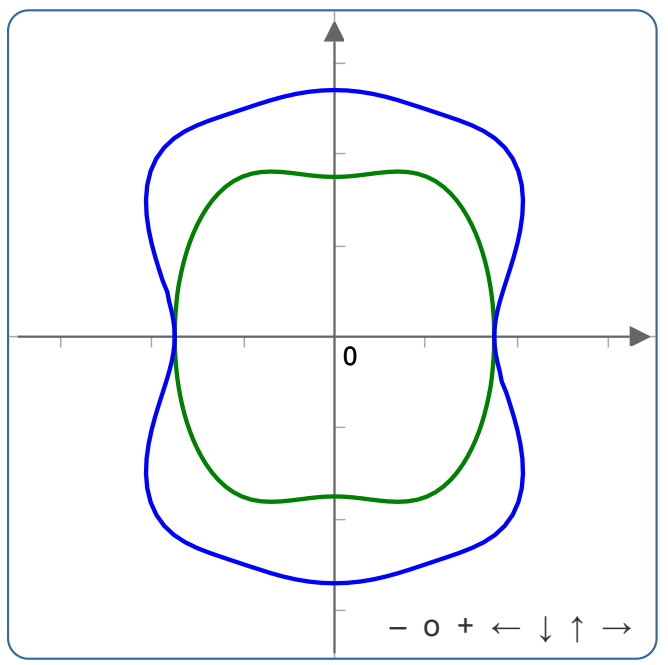

Shear modulus in (xy) plane

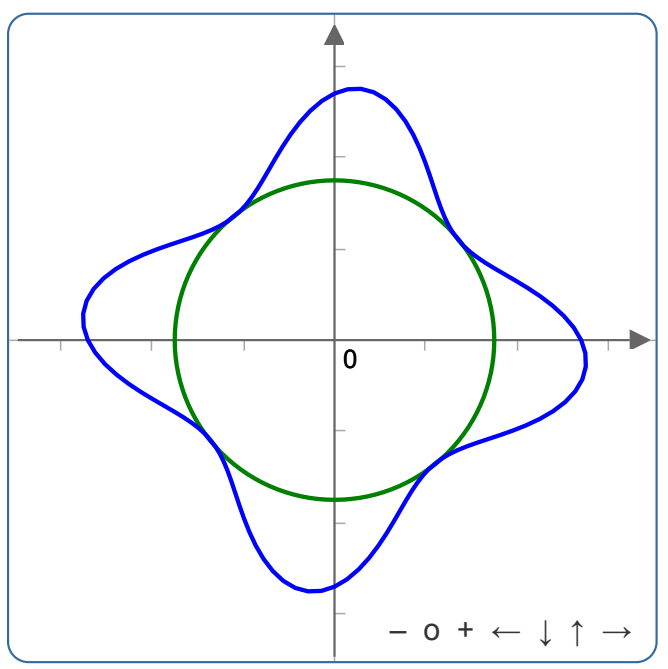

Shear modulus in (yz) plane

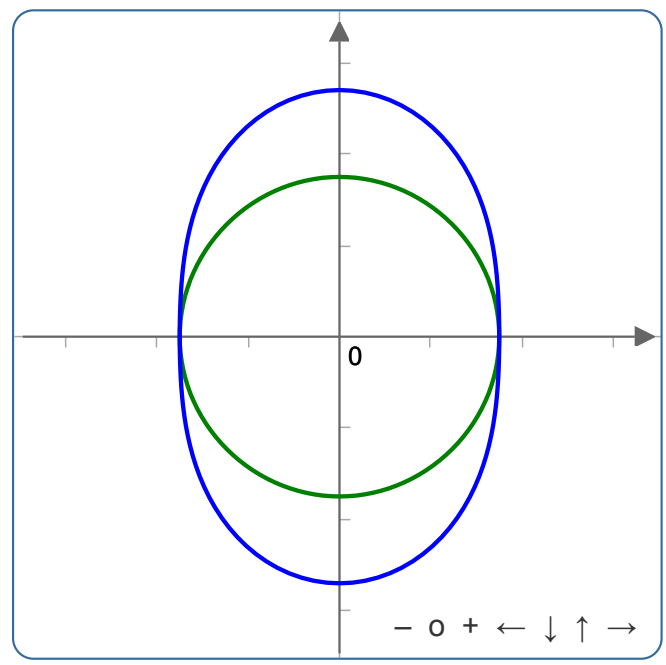

Shear modulus in (xz) plane

\section{Spatial dependence of Poisson's ratio}

\section{Visualize in 3D}




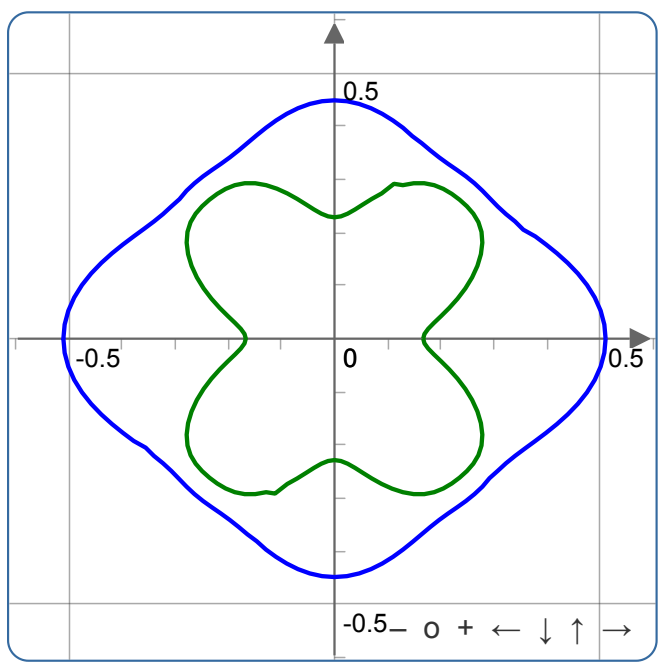

Poisson's ratio in (xy) plane

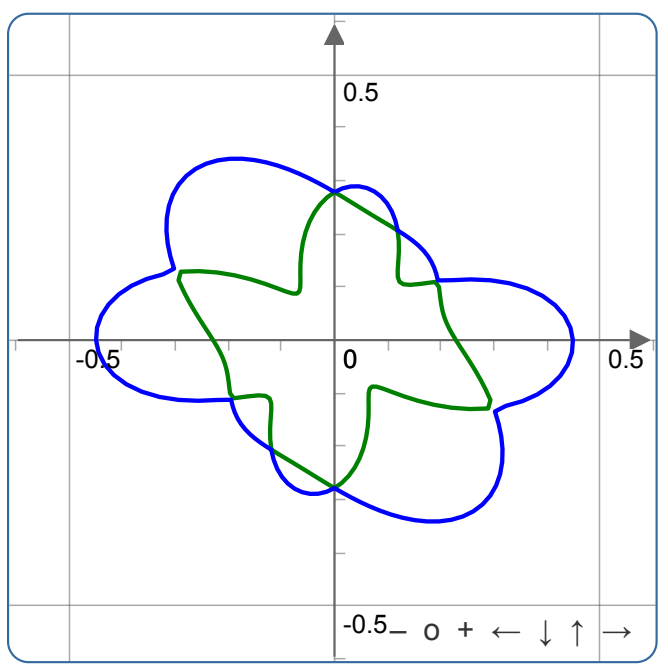

Poisson's ratio in (yz) plane

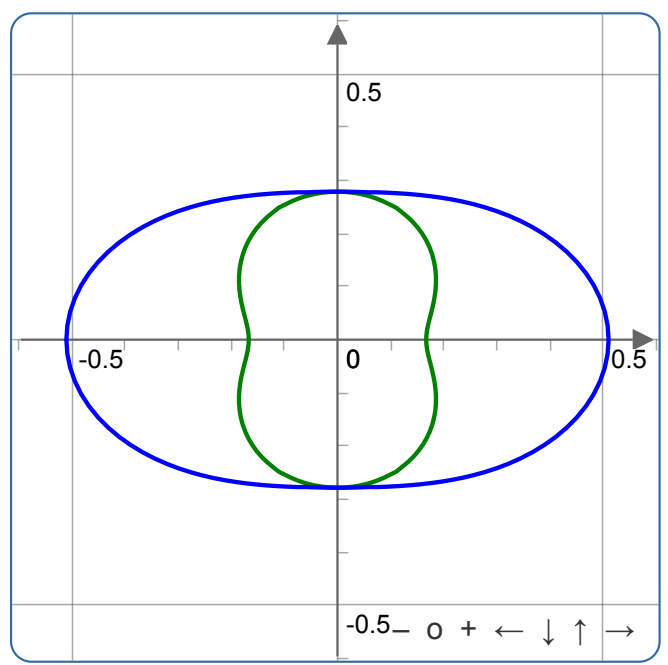

Poisson's ratio in (xz) plane

Code version: 2019.01.09 (running on Python 3.7.2)

Execution time: 3.120 seconds 


\section{ELATE: Elastic tensor analysis}

Welcome to ELATE, the online tool for analysis of elastic tensors, developed by Romain Gaillac and François-Xavier Coudert at CNRS / Chimie ParisTech.

If you use the software in published results (paper, conference, etc.), please cite the corresponding_paper ( $J$.

Phys. Condens. Matter, 2016, 28, 275201) and give the website URL.

ELATE is open source software. Any queries or comments are welcome at fx.coudert@ $\underline{\text { chimie-paristech.fr }}$

\section{Summary of the properties}

Input: stiffness matrix (coefficients in GPa) of MgSeO4-Isz (11.243 GPa)

$\begin{array}{rrrrrr}259.03 & 117.79 & 89.889 & 1.8694 & 0 & 0 \\ 117.79 & 259.03 & 89.889 & -1.8694 & 0 & 0 \\ 89.889 & 89.889 & 140.94 & 1 \mathrm{e}-05 & 0 & 0 \\ 1.8694 & -1.8694 & 1 \mathrm{e}-05 & 72.657 & 0 & 0 \\ 0 & 0 & 0 & 0 & 33.252 & 1 \mathrm{e}-05 \\ 0 & 0 & 0 & 0 & 1 \mathrm{e}-05 & 33.252\end{array}$

\section{Average properties}

\begin{tabular}{|c|c|c|c|c|}
\hline Averaging scheme & Bulk modulus & Young's modulus & Shear modulus & Poisson's ratio \\
\hline Voigt & $K_{\mathrm{V}}=139.35 \mathrm{GPa}$ & $E_{\mathrm{V}}=138.57 \mathrm{GPa}$ & $G_{\mathrm{V}}=51.928 \mathrm{GPa}$ & $V_{\mathrm{V}}=0.33426$ \\
\hline Reuss & $K_{\mathrm{R}}=123.52 \mathrm{GPa}$ & $E_{\mathrm{R}}=120.76 \mathrm{GPa}$ & $G_{\mathrm{R}}=45.16 \mathrm{GPa}$ & $v_{\mathrm{R}}=0.33705$ \\
\hline Hill & $K_{\mathrm{H}}=131.43 \mathrm{GPa}$ & $E_{\mathrm{H}}=129.67 \mathrm{GPa}$ & $G_{\mathrm{H}}=48.544 \mathrm{GPa}$ & $v_{\mathrm{H}}=0.33557$ \\
\hline
\end{tabular}

Eigenvalues of the stiffness matrix

\begin{tabular}{|c|c|c|c|c|c|}
\hline $\boldsymbol{\lambda}_{\mathbf{1}}$ & $\boldsymbol{\lambda}_{\mathbf{2}}$ & $\boldsymbol{\lambda}_{\mathbf{3}}$ & $\boldsymbol{\lambda}_{\mathbf{4}}$ & $\boldsymbol{\lambda}_{\mathbf{5}}$ & $\boldsymbol{\lambda}_{\mathbf{6}}$ \\
\hline $33.252 \mathrm{GPa}$ & $33.252 \mathrm{GPa}$ & $72.555 \mathrm{GPa}$ & $85.475 \mathrm{GPa}$ & $141.34 \mathrm{GPa}$ & $432.29 \mathrm{GPa}$ \\
\hline
\end{tabular}

Variations of the elastic moduli

\begin{tabular}{|c|c|c|c|c|c|c|c|c|c|}
\hline & \multicolumn{2}{|c|}{$\begin{array}{l}\text { Young's } \\
\text { modulus }\end{array}$} & \multicolumn{2}{|c|}{$\begin{array}{l}\text { Linear } \\
\text { compressibility }\end{array}$} & \multicolumn{2}{|c|}{ Shear modulus } & \multicolumn{2}{|c|}{ Poisson's ratio } & \\
\hline & $E_{\min }$ & $E_{\max }$ & $\beta_{\min }$ & $\beta_{\max }$ & $G_{\min }$ & $G_{\max }$ & $\mathbf{v}_{\min }$ & $\mathbf{v}_{\max }$ & \\
\hline Value & $\begin{array}{l}92.56 \\
\mathrm{GPa}\end{array}$ & $\begin{array}{c}192.63 \\
\mathrm{GPa}\end{array}$ & $\begin{array}{l}1.3816 \\
\mathrm{TPa}^{-1}\end{array}$ & $\begin{array}{l}5.3329 \\
\mathrm{TPa}^{-1}\end{array}$ & $\begin{array}{c}33.252 \\
\mathrm{GPa}\end{array}$ & $\begin{array}{l}72.634 \\
\mathrm{GPa}\end{array}$ & 0.10703 & 0.61772 & Value \\
\hline Anisotropy & \multicolumn{2}{|c|}{2.081} & \multicolumn{2}{|c|}{3.8599} & \multicolumn{2}{|c|}{2.184} & \multicolumn{2}{|c|}{5.7712} & Anisotropy \\
\hline Axis & $\begin{array}{c}0.5017 \\
-0.0049 \\
0.8650\end{array}$ & $\begin{array}{c}-0.0000 \\
0.9170 \\
-0.3988\end{array}$ & $\begin{array}{r}-0.0000 \\
1.0000 \\
0.0000\end{array}$ & $\begin{array}{l}0.0000 \\
0.0000 \\
1.0000\end{array}$ & $\begin{array}{l}0.0000 \\
0.0000 \\
1.0000\end{array}$ & $\begin{array}{c}0.0000 \\
-0.0135 \\
0.9999\end{array}$ & $\begin{array}{c}-0.3450 \\
0.6076 \\
0.7154\end{array}$ & $\begin{array}{c}-0.7106 \\
0.5959 \\
0.3741\end{array}$ & Axis \\
\hline
\end{tabular}




\section{Spatial dependence of Young's modulus}

\section{Visualize in 3D}

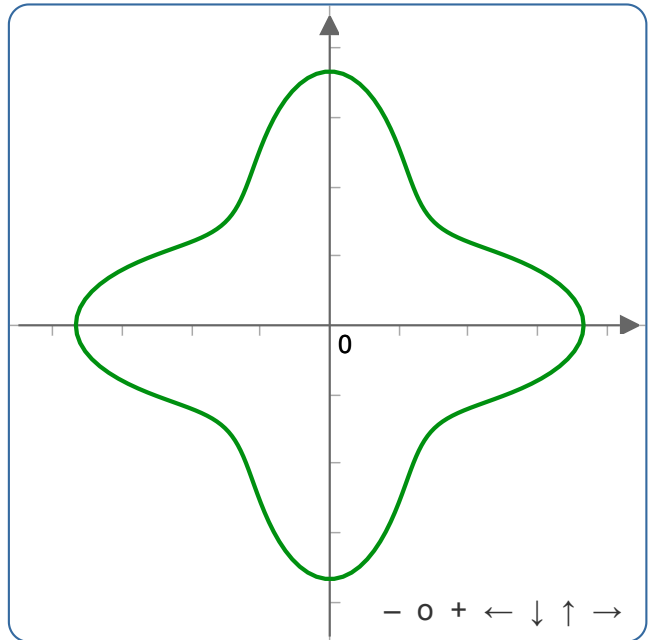

Young's modulus in (xy) plane

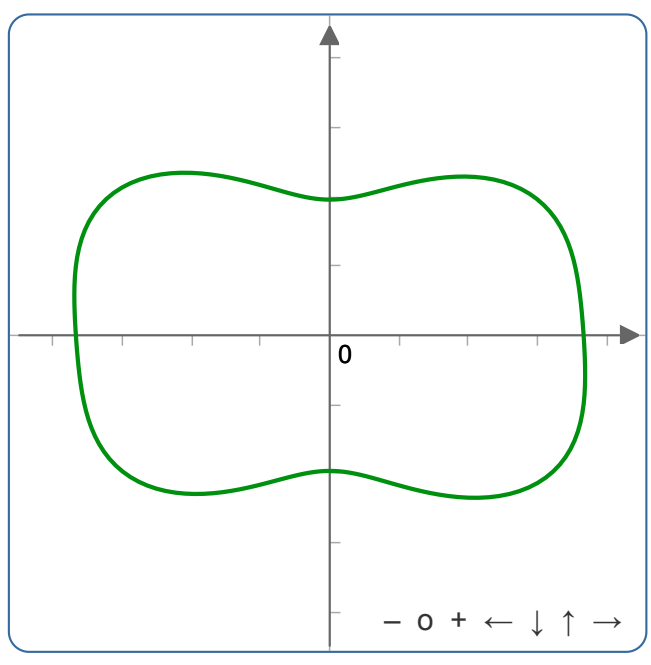

Young's modulus in (yz) plane

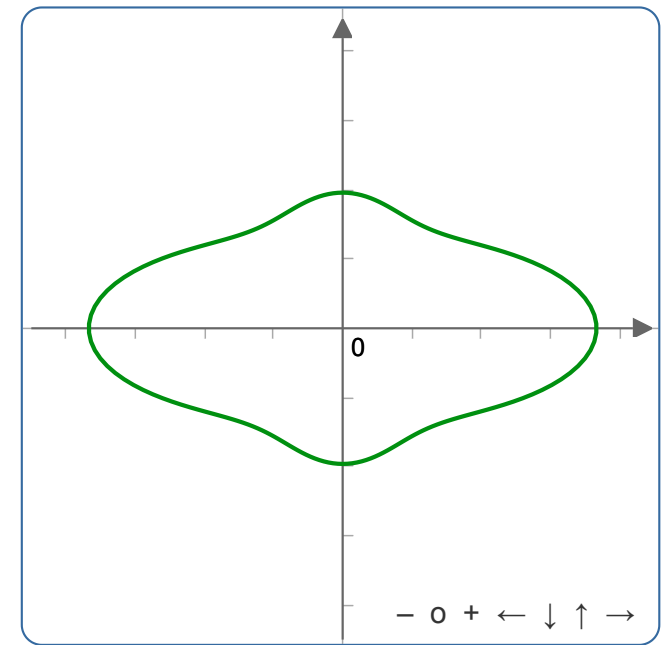

Young's modulus in (xz) plane

\section{Spatial dependence of linear compressibility}

Visualize in 3D 


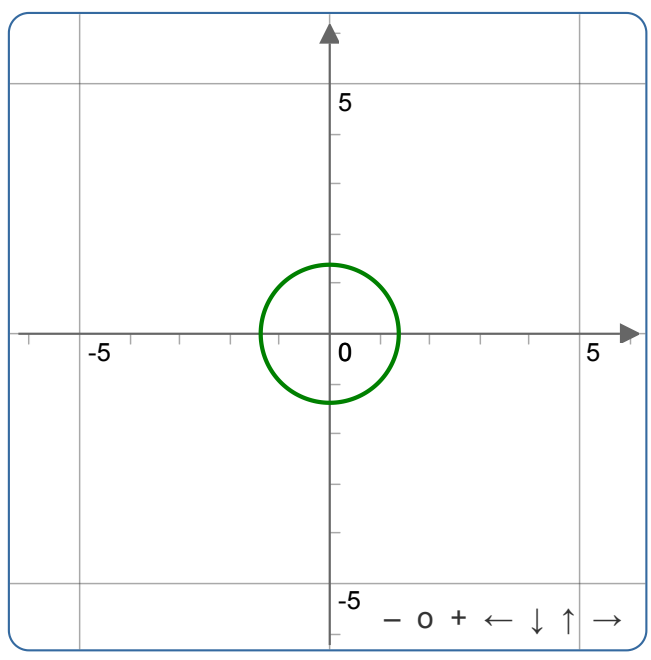

linear compressibility in (xy) plane

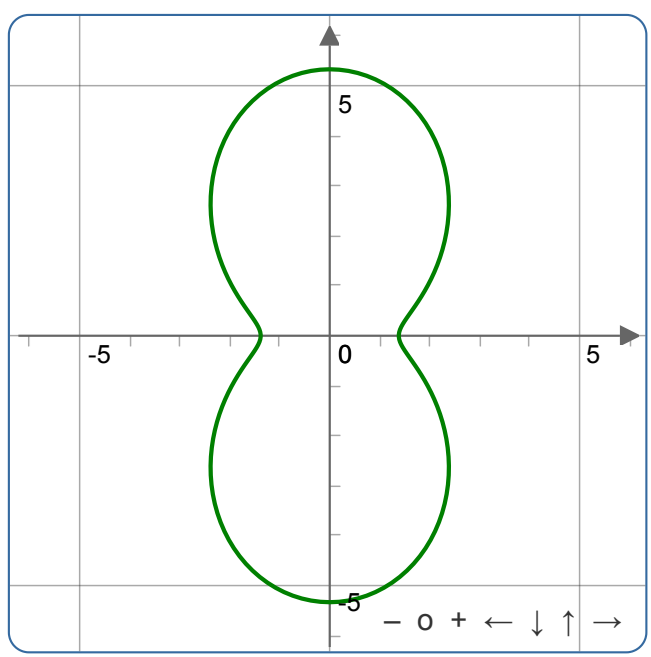

linear compressibility in (yz) plane

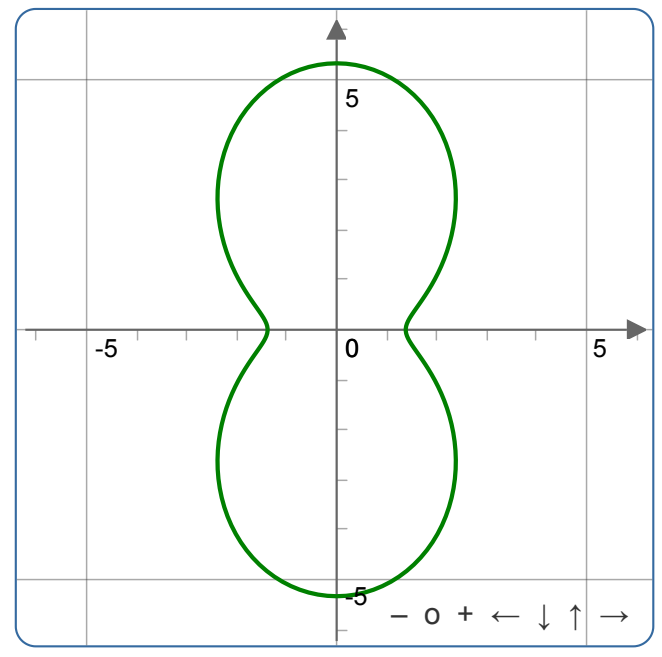

linear compressibility in (xz) plane

\section{Spatial dependence of shear modulus}

\section{Visualize in 3D}




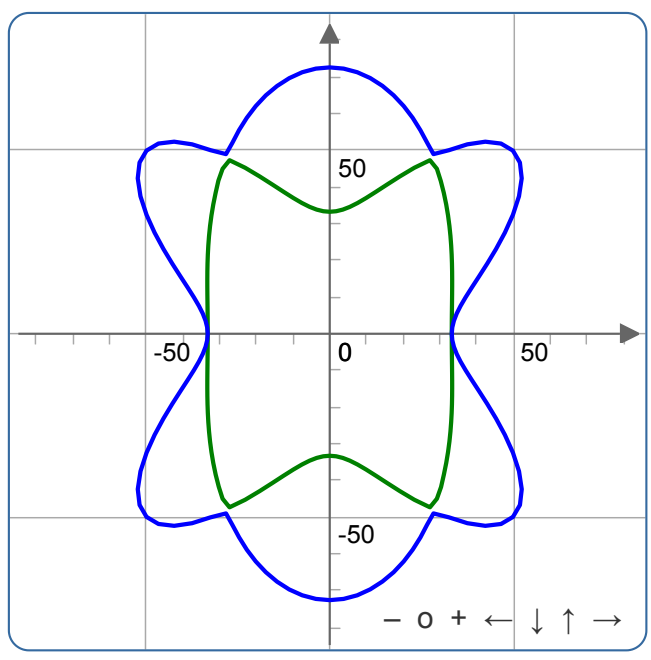

Shear modulus in (xy) plane

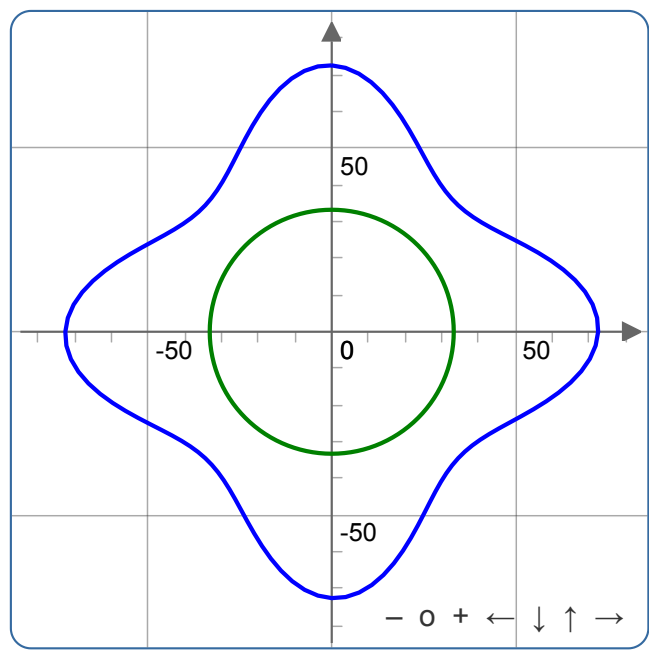

Shear modulus in (yz) plane

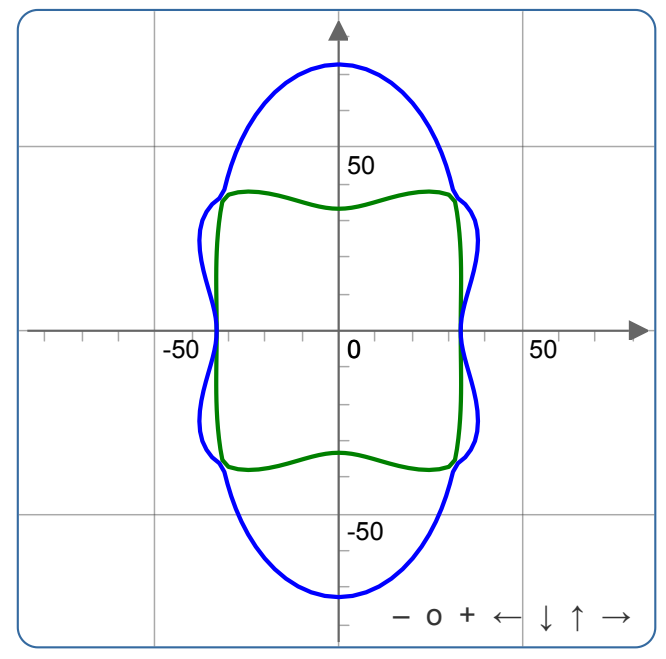

Shear modulus in (xz) plane

\section{Spatial dependence of Poisson's ratio}

\section{Visualize in 3D}




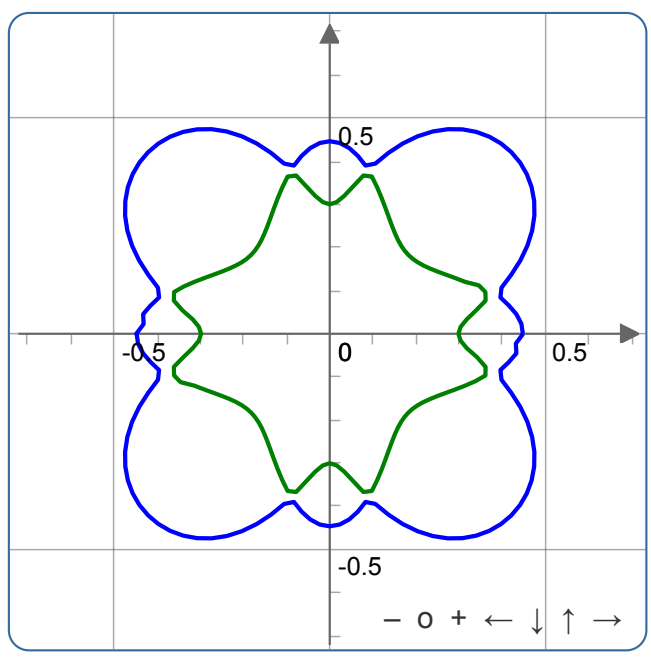

Poisson's ratio in (xy) plane

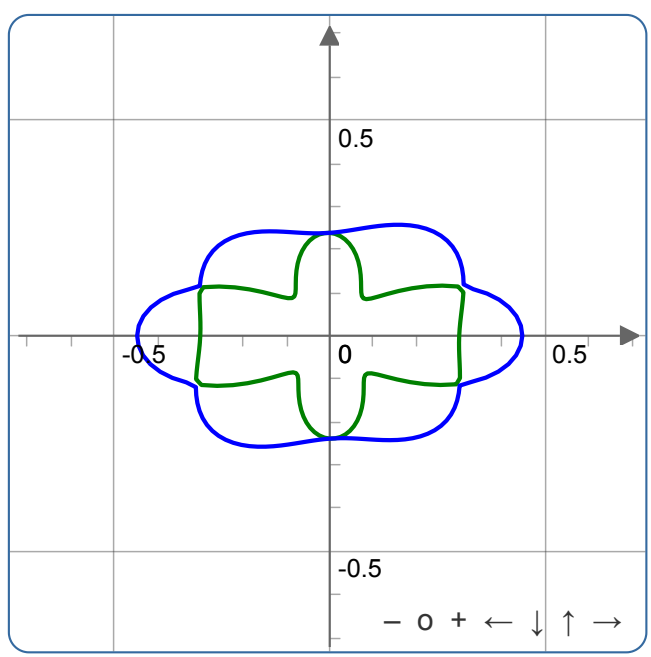

Poisson's ratio in (yz) plane

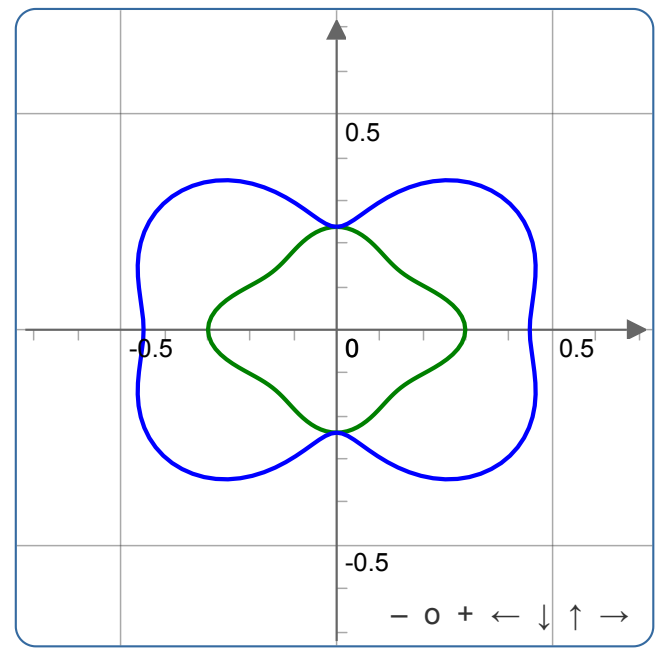

Poisson's ratio in (xz) plane

Code version: 2019.01 .09 (running on Python 3.7.2)

Execution time: 2.990 seconds 


\section{ELATE: Elastic tensor analysis}

Welcome to ELATE, the online tool for analysis of elastic tensors, developed by Romain Gaillac and François-Xavier Coudert at CNRS / Chimie ParisTech. If you use the software in published results (paper, conference, etc.), please cite the corresponding_paper (J. Phys. Condens. Matter, 2016, 28, 275201) and give the website URL.

ELATE is open source software. Any queries or comments are welcome at fx.coudert@ chimie-paristech.fr

\section{Summary of the properties}

Input: stiffness matrix (coefficients in GPa) of CaSO4-7,7T3 (70.77 GPa)

$\begin{array}{rrrrrr}493.76 & 209.94 & 138.35 & 0 & 0 & 0 \\ 209.94 & 400.79 & 237.38 & 0 & 0 & 0 \\ 138.35 & 237.38 & 454.03 & 0 & 0 & 0 \\ 0 & 0 & 0 & 111.13 & 0 & 0 \\ 0 & 0 & 0 & 0 & -900.49 & 0 \\ 0 & 0 & 0 & 0 & 0 & 49.508\end{array}$

\section{Average properties}

\begin{tabular}{|c|c|c|c|c|}
\hline $\begin{array}{l}\text { Averaging } \\
\text { scheme }\end{array}$ & $\begin{array}{c}\text { Bulk } \\
\text { modulus }\end{array}$ & $\begin{array}{l}\text { Young's } \\
\text { modulus }\end{array}$ & $\begin{array}{l}\text { Shear } \\
\text { modulus }\end{array}$ & $\begin{array}{l}\text { Poisson's } \\
\text { ratio }\end{array}$ \\
\hline Voigt & $\begin{array}{c}K_{\mathrm{V}}=279.99 \\
\mathrm{GPa}\end{array}$ & $\begin{array}{c}E_{\mathrm{V}}=-329.41 \\
\mathrm{GPa}\end{array}$ & $\begin{array}{c}G_{\vee}=-97.11 \\
G P a\end{array}$ & $\begin{array}{c}v_{V}= \\
0.69609\end{array}$ \\
\hline Reuss & $\begin{array}{c}K_{\mathrm{R}}=279.89 \\
\mathrm{GPa}\end{array}$ & $\begin{array}{c}E_{\mathrm{R}}=289.63 \\
\mathrm{GPa}\end{array}$ & $\begin{array}{c}G_{R}=109.09 \\
G P a\end{array}$ & $\begin{array}{c}v_{R}= \\
0.32753\end{array}$ \\
\hline Hill & $\begin{array}{c}K_{\mathrm{H}}=279.94 \\
\mathrm{GPa}\end{array}$ & $\begin{array}{c}E_{\mathrm{H}}=17.837 \\
\mathrm{GPa}\end{array}$ & $\begin{array}{c}G_{H}=5.988 \\
G P a\end{array}$ & $\begin{array}{c}v_{H}= \\
0.48938\end{array}$ \\
\hline
\end{tabular}

Eigenvalues of the stiffness matrix

\begin{tabular}{|c|c|c|c|c|c|}
\hline$\lambda_{1}$ & $\lambda_{2}$ & $\lambda_{3}$ & $\lambda_{4}$ & $\lambda_{5}$ & $\lambda_{6}$ \\
\hline $\begin{array}{c}-900.49 \\
\mathrm{GPa}\end{array}$ & $\begin{array}{c}49.508 \\
\mathrm{GPa}\end{array}$ & $\begin{array}{c}111.13 \\
\mathrm{GPa}\end{array}$ & $\begin{array}{c}168.53 \\
\mathrm{GPa}\end{array}$ & $\begin{array}{c}339.98 \\
\text { GPa }\end{array}$ & $\begin{array}{c}840.07 \\
\mathrm{GPa}\end{array}$ \\
\hline
\end{tabular}


Stiffness matrix is not definite positive, crystal is mechanically unstable No further analysis will be performed.

Code version: 2019.01 .09 (running on Python 3.7.2)

Execution time: 0.000 seconds

Specific (faster) code for orthorhombic case was used. 


\section{ELATE: Elastic tensor analysis}

Welcome to ELATE, the online tool for analysis of elastic tensors, developed by Romain Gaillac and François-Xavier Coudert at CNRS / Chimie ParisTech.

If you use the software in published results (paper, conference, etc.), please cite the corresponding paper ( $J$.

Phys. Condens. Matter, 2016, 28, 275201) and give the website URL.

ELATE is open source software. Any queries or comments are welcome at fx.coudert@ $\underline{\text { chimie-paristech.fr }}$

\section{Summary of the properties}

Input: stiffness matrix (coefficients in GPa) of SrSO4-bcu7-P21_c (2.057 GPa)

$\begin{array}{rrrrrr}94.567 & 36.6 & 44.701 & 0 & 0 & 12.032 \\ 36.6 & 127.5 & 44.015 & 0 & 0 & 8.4606 \\ 44.701 & 44.015 & 138.92 & 0 & 0 & -10.487 \\ 0 & 0 & 0 & 24.341 & 4.3701 & 0 \\ 0 & 0 & 0 & 4.3701 & 29.227 & 0 \\ 12.032 & 8.4606 & -10.487 & 0 & 0 & 31.326\end{array}$

\section{Average properties}

\begin{tabular}{|c|c|c|c|c|}
\hline Averaging scheme & Bulk modulus & Young's modulus & Shear modulus & Poisson's ratio \\
\hline Voigt & $K_{\mathrm{V}}=67.958 \mathrm{GPa}$ & $E_{\mathrm{V}}=84.519 \mathrm{GPa}$ & $G_{\mathrm{V}}=32.69 \mathrm{GPa}$ & $v_{\mathrm{V}}=0.29272$ \\
\hline Reuss & $K_{\mathrm{R}}=64.524 \mathrm{GPa}$ & $E_{\mathrm{R}}=76.097 \mathrm{GPa}$ & $G_{\mathrm{R}}=29.191 \mathrm{GPa}$ & $v_{\mathrm{R}}=0.30344$ \\
\hline Hill & $K_{\mathrm{H}}=66.241 \mathrm{GPa}$ & $E_{\mathrm{H}}=80.317 \mathrm{GPa}$ & $G_{\mathrm{H}}=30.941 \mathrm{GPa}$ & $v_{\mathrm{H}}=0.29792$ \\
\hline
\end{tabular}

Eigenvalues of the stiffness matrix

\begin{tabular}{|c|c|c|c|c|c|}
\hline $\boldsymbol{\lambda}_{\mathbf{1}}$ & $\boldsymbol{\lambda}_{\mathbf{2}}$ & $\boldsymbol{\lambda}_{\mathbf{3}}$ & $\boldsymbol{\lambda}_{\mathbf{4}}$ & $\boldsymbol{\lambda}_{\mathbf{5}}$ & $\boldsymbol{\lambda}_{\mathbf{6}}$ \\
\hline $21.777 \mathrm{GPa}$ & $24.831 \mathrm{GPa}$ & $31.791 \mathrm{GPa}$ & $68.448 \mathrm{GPa}$ & $91.77 \mathrm{GPa}$ & $207.27 \mathrm{GPa}$ \\
\hline
\end{tabular}

Variations of the elastic moduli

\begin{tabular}{|c|c|c|c|c|c|c|c|c|c|}
\hline & \multicolumn{2}{|c|}{$\begin{array}{l}\text { Young's } \\
\text { modulus }\end{array}$} & \multicolumn{2}{|c|}{$\begin{array}{c}\text { Linear } \\
\text { compressibility }\end{array}$} & \multicolumn{2}{|c|}{ Shear modulus } & \multicolumn{2}{|c|}{ Poisson's ratio } & \\
\hline & $E_{\min }$ & $E_{\max }$ & $\beta_{\min }$ & $\beta_{\max }$ & $G_{\min }$ & $G_{\max }$ & $v_{\min }$ & $v_{\max }$ & \\
\hline Value & $\begin{array}{l}51.23 \\
\mathrm{GPa}\end{array}$ & $\begin{array}{c}111.67 \\
\mathrm{GPa}\end{array}$ & $\begin{array}{l}2.9288 \\
\mathrm{TPa}^{-1}\end{array}$ & $\begin{array}{l}8.4841 \\
\mathrm{TPa}^{-1}\end{array}$ & $\begin{array}{l}21.736 \\
\mathrm{GPa}\end{array}$ & $\begin{array}{c}49.541 \\
\mathrm{GPa}\end{array}$ & 0.047783 & 0.65444 & Value \\
\hline Anisotropy & \multicolumn{2}{|c|}{2.18} & \multicolumn{2}{|c|}{2.8967} & \multicolumn{2}{|c|}{2.279} & \multicolumn{2}{|c|}{13.6959} & Anisotropy \\
\hline Axis & $\begin{array}{c}-0.8388 \\
0.5445 \\
-0.0000\end{array}$ & $\begin{array}{l}0.2327 \\
0.9725 \\
0.0000\end{array}$ & $\begin{array}{l}0.0000 \\
0.0000 \\
1.0000\end{array}$ & $\begin{array}{l}-0.9116 \\
0.4111 \\
0.0000\end{array}$ & $\begin{array}{l}-0.3956 \\
-0.0048 \\
0.9184\end{array}$ & $\begin{array}{l}0.3758 \\
0.5990 \\
0.7071\end{array}$ & $\begin{array}{c}-0.0000 \\
0.0000 \\
-1.0000\end{array}$ & $\begin{array}{c}0.0000 \\
0.0000 \\
-1.0000\end{array}$ & Axis \\
\hline
\end{tabular}




\section{Spatial dependence of Young's modulus}

\section{Visualize in 3D}

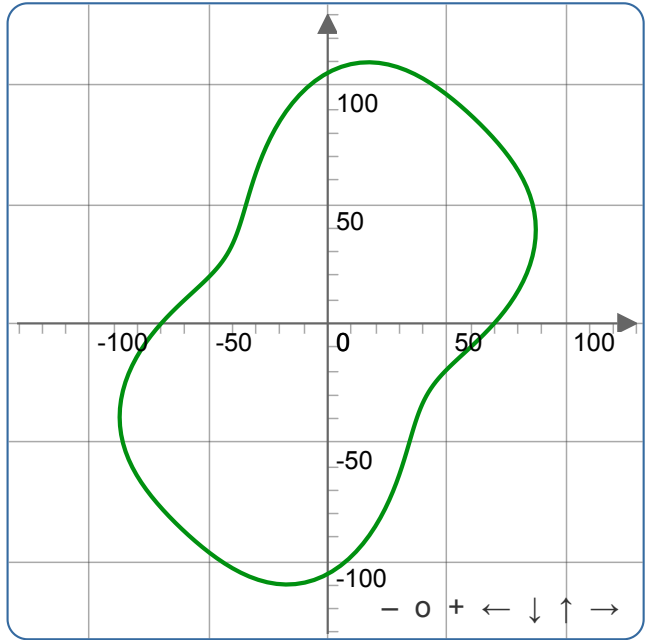

Young's modulus in (xy) plane

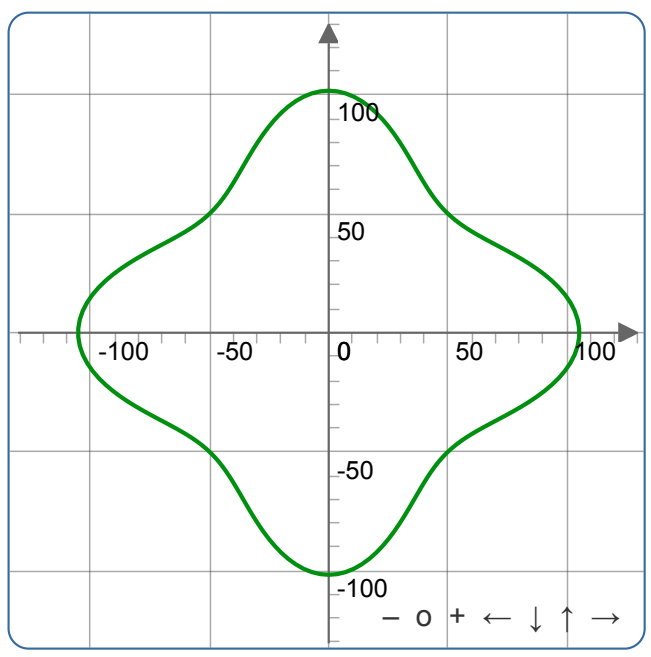

Young's modulus in (yz) plane

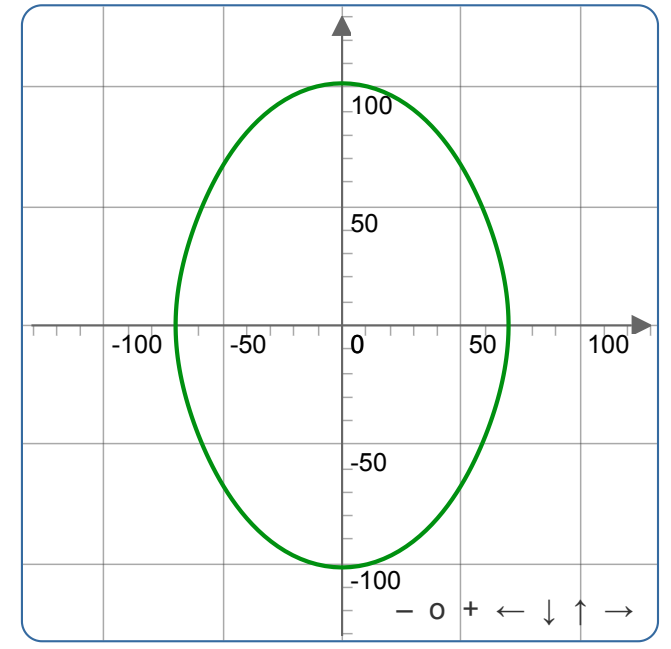

Young's modulus in (xz) plane 


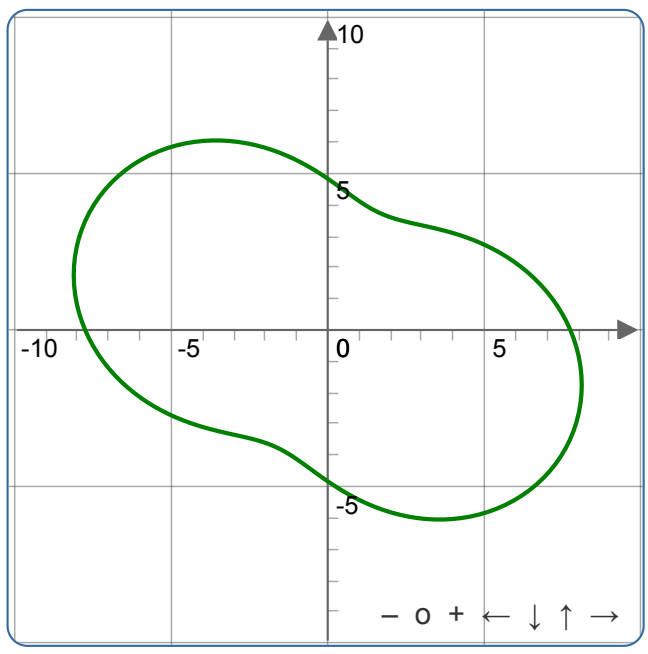

linear compressibility in (xy) plane

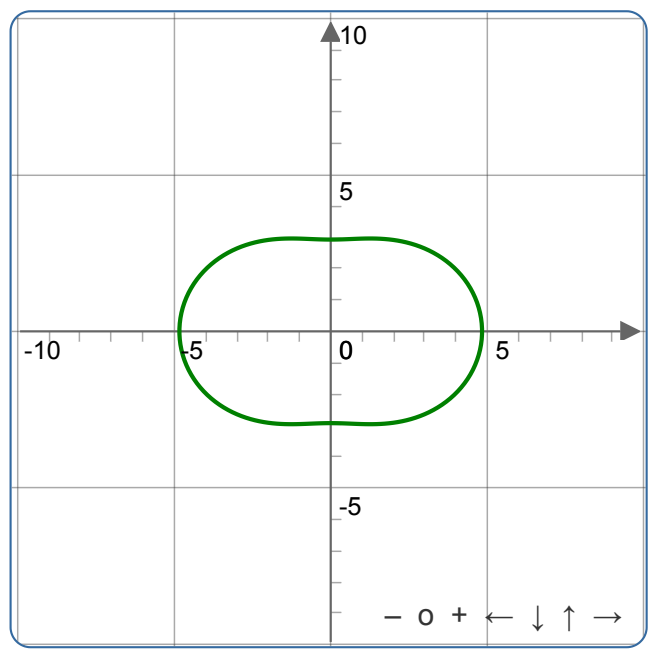

linear compressibility in (yz) plane

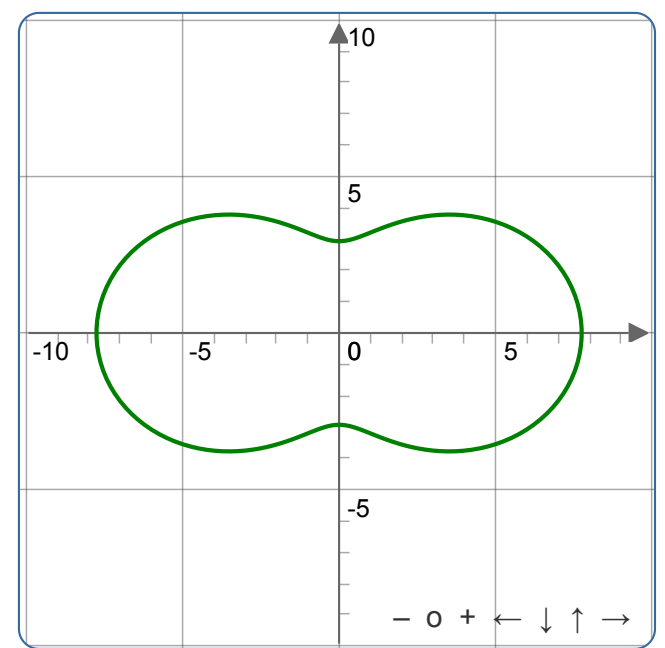

linear compressibility in (xz) plane

\section{Spatial dependence of shear modulus}

Visualize in 3D 


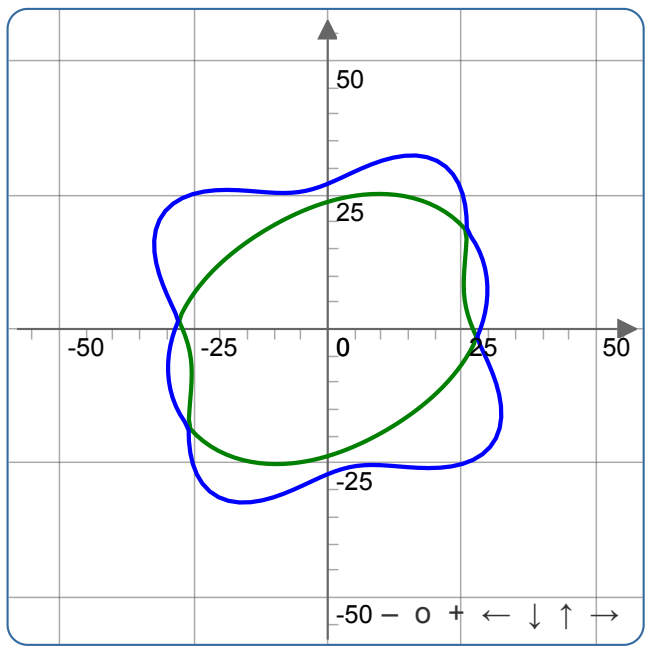

Shear modulus in (xy) plane

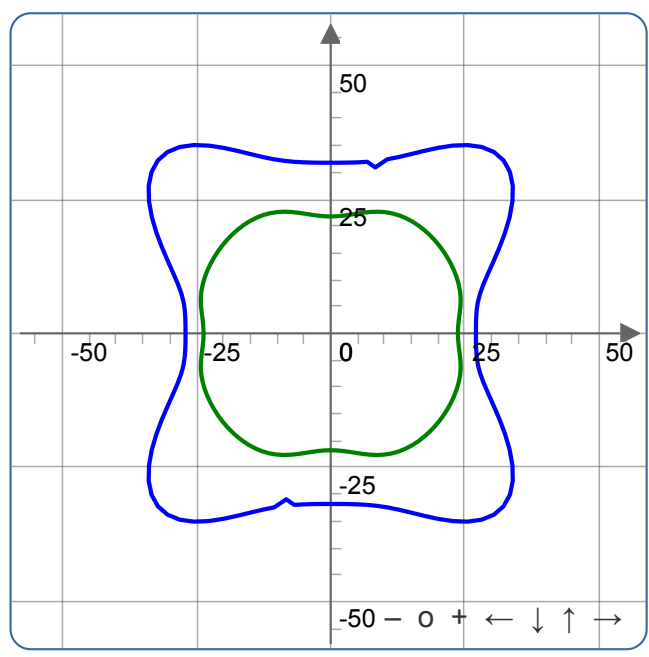

Shear modulus in (yz) plane

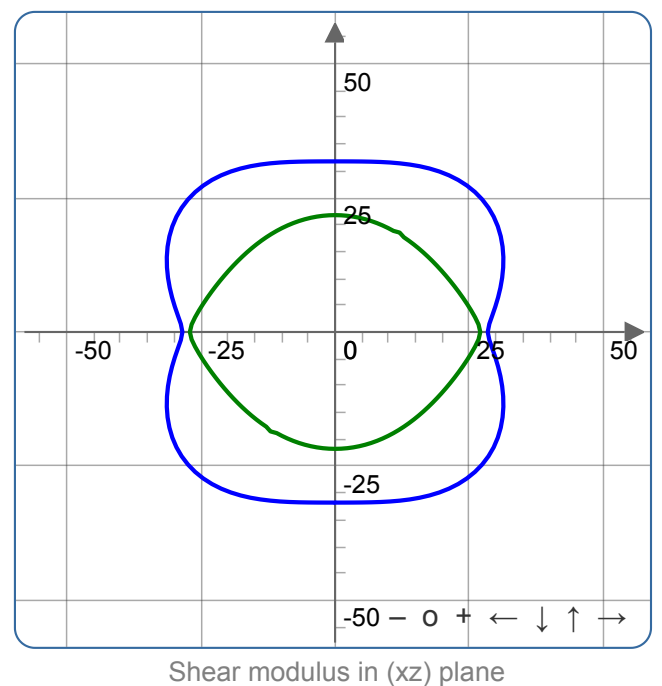

Shear modulus in (xz) plane

\section{Spatial dependence of Poisson's ratio}

Visualize in 3D 


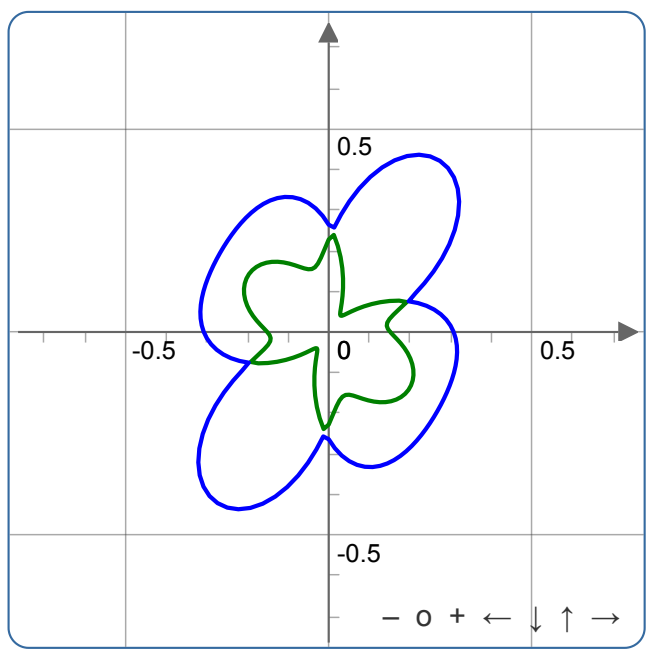

Poisson's ratio in (xy) plane

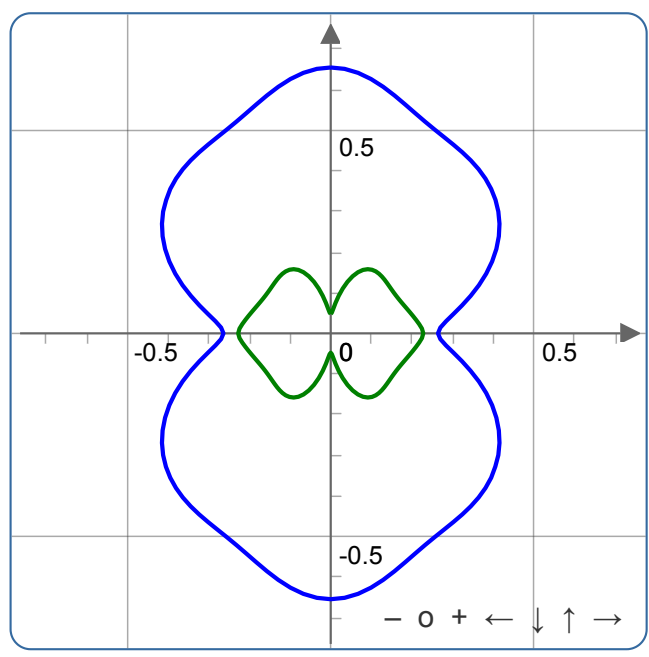

Poisson's ratio in (yz) plane

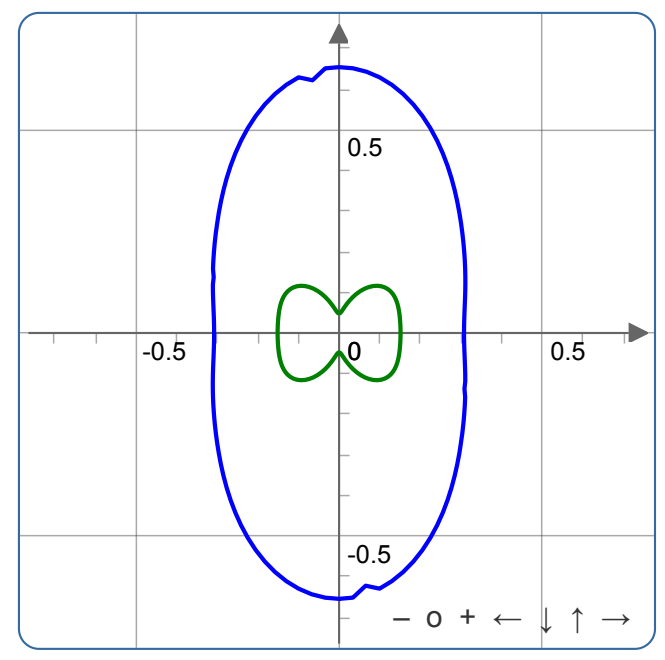

Poisson's ratio in (xz) plane

Code version: 2019.01.09 (running on Python 3.7.2)

Execution time: 3.410 seconds 


\section{ELATE: Elastic tensor analysis}

Welcome to ELATE, the online tool for analysis of elastic tensors, developed by Romain Gaillac and FrançoisXavier Coudert at CNRS / Chimie ParisTech.

If you use the software in published results (paper, conference, etc.), please cite the corresponding_paper ( $J$.

Phys. Condens. Matter, 2016, 28, 275201) and give the website URL.

ELATE is open source software. Any queries or comments are welcome at fx.coudert@chimie-paristech.fr

\section{Summary of the properties}

Input: stiffness matrix (coefficients in GPa) of SrSO4-hxg-d-8-Pbcm (49.747 GPa)

$\begin{array}{rrrrrr}289.39 & 164.34 & 101.68 & 0 & 0 & 0 \\ 164.34 & 384.25 & 154.62 & 0 & 0 & 0 \\ 101.68 & 154.62 & 381.16 & 0 & 0 & 0 \\ 0 & 0 & 0 & 131.93 & 0 & 0 \\ 0 & 0 & 0 & 0 & 127.64 & 0 \\ 0 & 0 & 0 & 0 & 0 & 89\end{array}$

\section{Average properties}

\begin{tabular}{|c|c|c|c|c|}
\hline Averaging scheme & Bulk modulus & Young's modulus & Shear modulus & Poisson's ratio \\
\hline Voigt & $K_{\mathrm{V}}=210.67 \mathrm{GPa}$ & $E_{\mathrm{V}}=285.41 \mathrm{GPa}$ & $G_{\mathrm{V}}=111.99 \mathrm{GPa}$ & $v_{\mathrm{V}}=0.27421$ \\
\hline Reuss & $K_{\mathrm{R}}=203.63 \mathrm{GPa}$ & $E_{\mathrm{R}}=273.59 \mathrm{GPa}$ & $G_{\mathrm{R}}=107.2 \mathrm{GPa}$ & $v_{\mathrm{R}}=0.27607$ \\
\hline Hill & $K_{\mathrm{H}}=207.15 \mathrm{GPa}$ & $E_{\mathrm{H}}=279.5 \mathrm{GPa}$ & $G_{\mathrm{H}}=109.6 \mathrm{GPa}$ & $v_{\mathrm{H}}=0.27512$ \\
\hline
\end{tabular}

Eigenvalues of the stiffness matrix

\begin{tabular}{|c|c|c|c|c|c|}
\hline $\boldsymbol{\lambda}_{\mathbf{1}}$ & $\boldsymbol{\lambda}_{\mathbf{2}}$ & $\boldsymbol{\lambda}_{\mathbf{3}}$ & $\boldsymbol{\lambda}_{\mathbf{4}}$ & $\boldsymbol{\lambda}_{\mathbf{5}}$ & $\boldsymbol{\lambda}_{\mathbf{6}}$ \\
\hline $89 \mathrm{GPa}$ & $127.64 \mathrm{GPa}$ & $131.93 \mathrm{GPa}$ & $164.61 \mathrm{GPa}$ & $250.33 \mathrm{GPa}$ & $639.86 \mathrm{GPa}$ \\
\hline
\end{tabular}

Variations of the elastic moduli

\begin{tabular}{|c|c|c|c|c|c|c|c|c|c|}
\hline & \multicolumn{2}{|c|}{$\begin{array}{l}\text { Young's } \\
\text { modulus }\end{array}$} & \multicolumn{2}{|c|}{$\begin{array}{l}\text { Linear } \\
\text { compressibility }\end{array}$} & \multicolumn{2}{|c|}{ Shear modulus } & \multicolumn{2}{|c|}{ Poisson's ratio } & \\
\hline & $E_{\min }$ & $E_{\max }$ & $\beta_{\min }$ & $\beta_{\max }$ & $G_{\min }$ & $G_{\max }$ & $v_{\min }$ & $v_{\max }$ & \\
\hline Value & $\begin{array}{c}215.15 \\
\mathrm{GPa}\end{array}$ & $\begin{array}{c}327.77 \\
\mathrm{GPa}\end{array}$ & $\begin{array}{l}0.94865 \\
\mathrm{TPa}^{-1}\end{array}$ & $\begin{array}{l}2.3505 \\
\mathrm{TPa}^{-1}\end{array}$ & $\begin{array}{l}83.346 \\
\mathrm{GPa}\end{array}$ & $\begin{array}{c}131.93 \\
\mathrm{GPa}\end{array}$ & 0.069607 & 0.46933 & Value \\
\hline Anisotropy & \multicolumn{2}{|c|}{1.523} & \multicolumn{2}{|c|}{2.4778} & \multicolumn{2}{|c|}{1.583} & \multicolumn{2}{|c|}{6.7426} & Anisotropy \\
\hline Axis & $\begin{array}{l}1.0000 \\
0.0000 \\
0.0000\end{array}$ & $\begin{array}{c}-0.0000 \\
0.5520 \\
0.8339\end{array}$ & $\begin{array}{l}0.0000 \\
1.0000 \\
0.0000\end{array}$ & $\begin{array}{l}1.0000 \\
0.0000 \\
0.0000\end{array}$ & $\begin{array}{c}-0.7071 \\
0.7071 \\
-0.0000\end{array}$ & $\begin{array}{c}-0.0000 \\
0.0000 \\
1.0000\end{array}$ & $\begin{array}{c}0.7431 \\
0.0001 \\
-0.6692\end{array}$ & $\begin{array}{c}-0.0000 \\
1.0000 \\
0.0000\end{array}$ & Axis \\
\hline
\end{tabular}




\section{Spatial dependence of Young's modulus}

\section{Visualize in 3D}

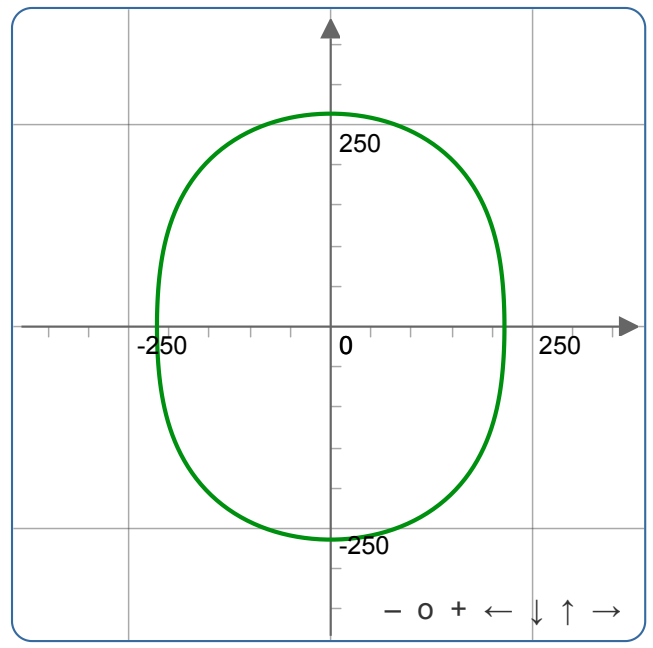

Young's modulus in (xy) plane

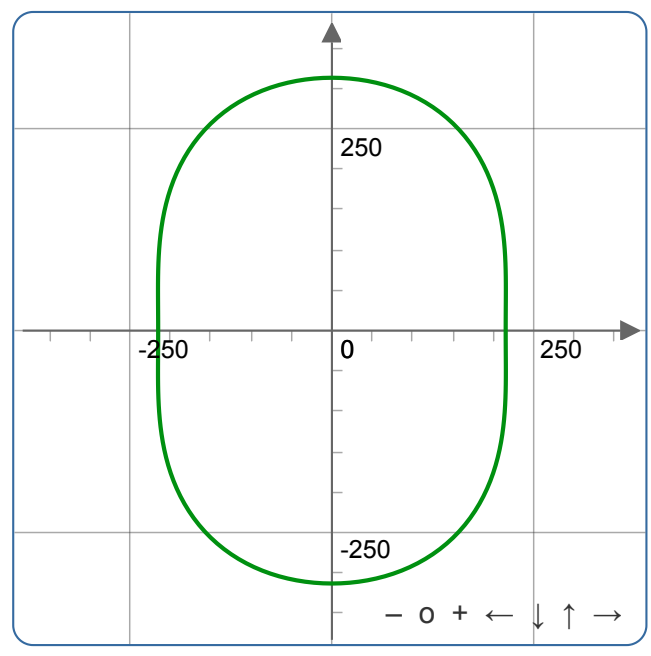

Young's modulus in (xz) plane

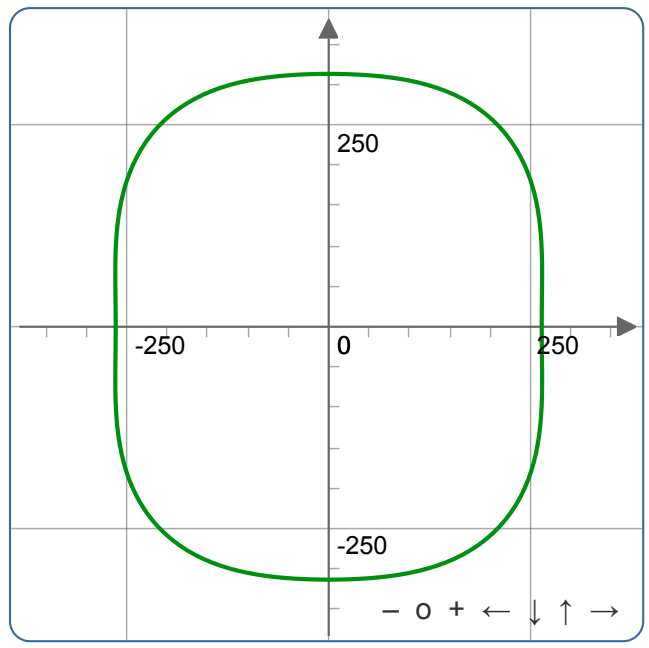

Young's modulus in (yz) plane

\section{Spatial dependence of linear compressibility}

\section{Visualize in 3D}




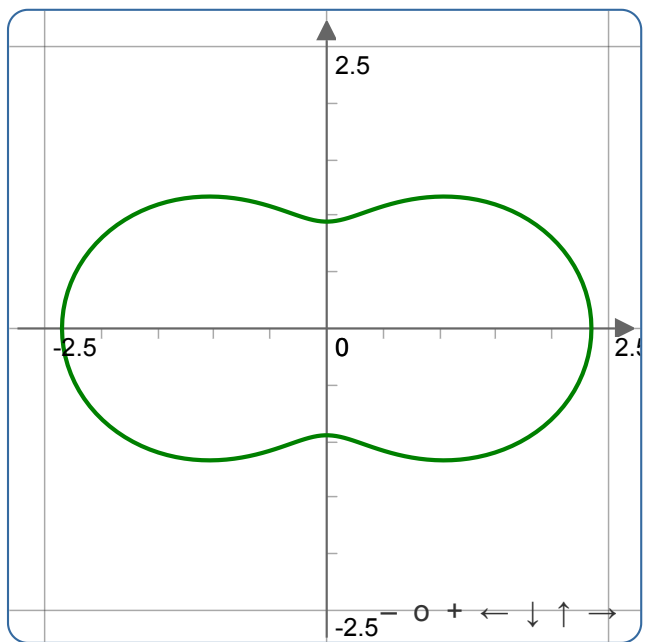

linear compressibility in (xy) plane

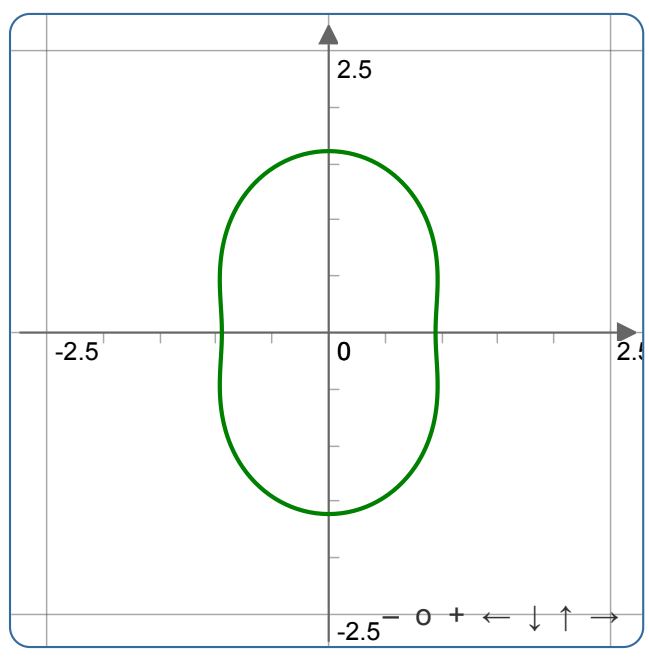

linear compressibility in (yz) plane

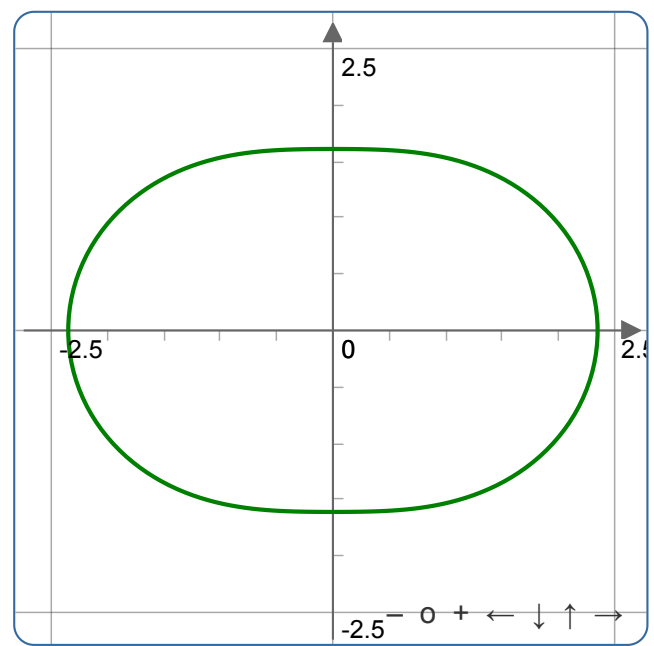

linear compressibility in (xz) plane

\section{Spatial dependence of shear modulus}

\section{Visualize in 3D}




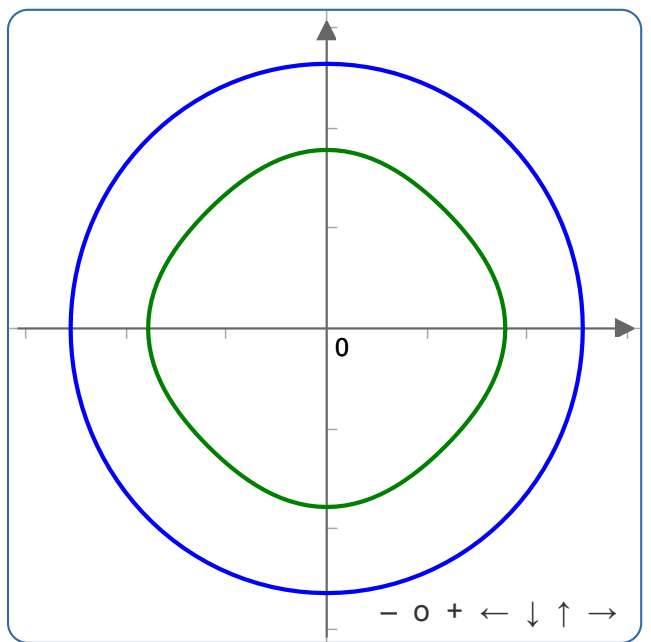

Shear modulus in (xy) plane

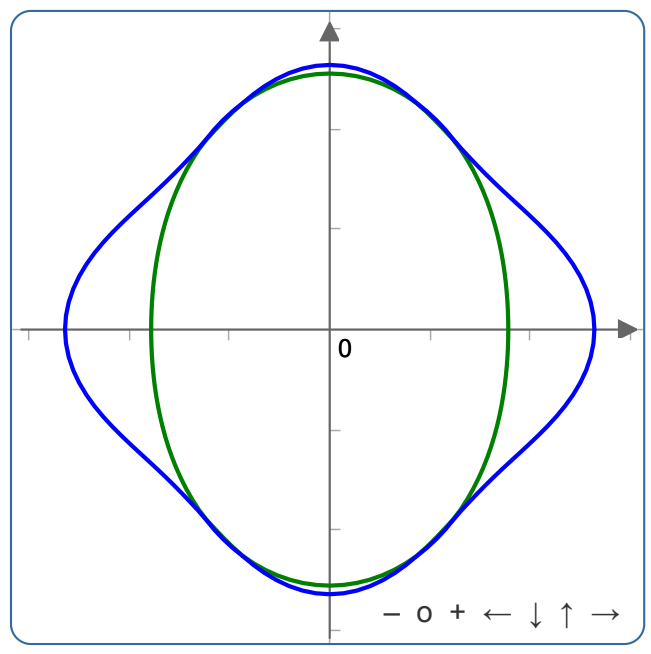

Shear modulus in (yz) plane

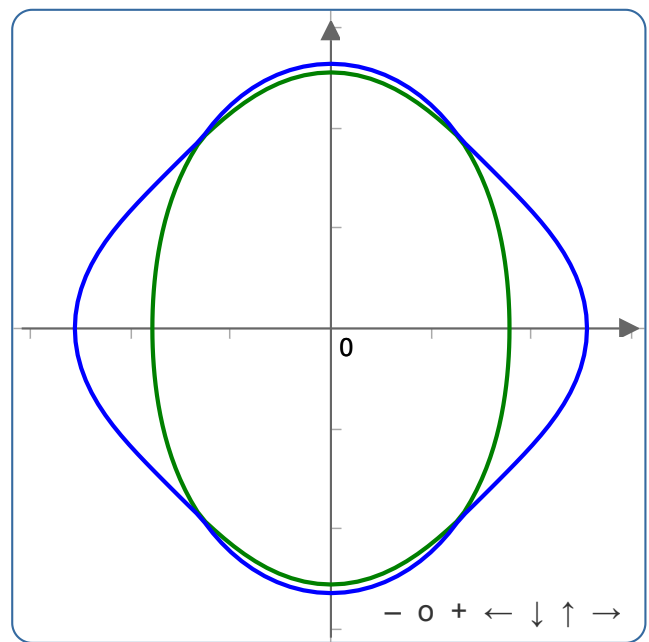

Shear modulus in (xz) plane

Spatial dependence of Poisson's ratio 


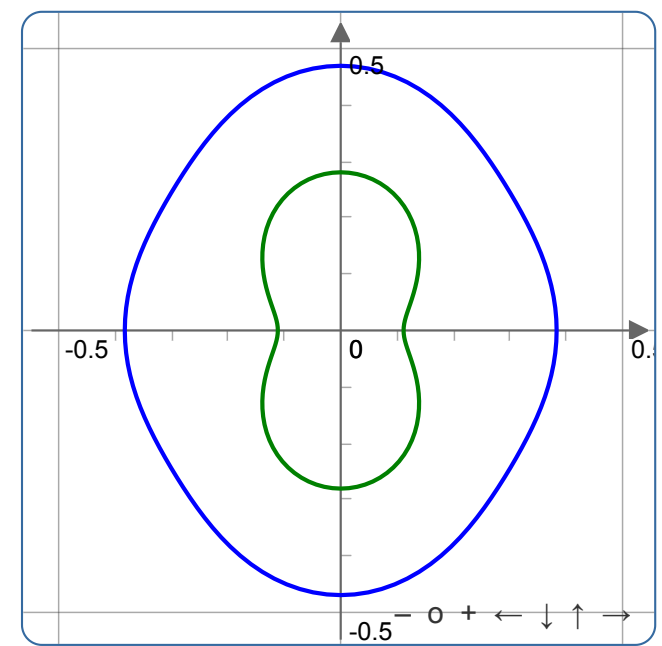

Poisson's ratio in (xy) plane

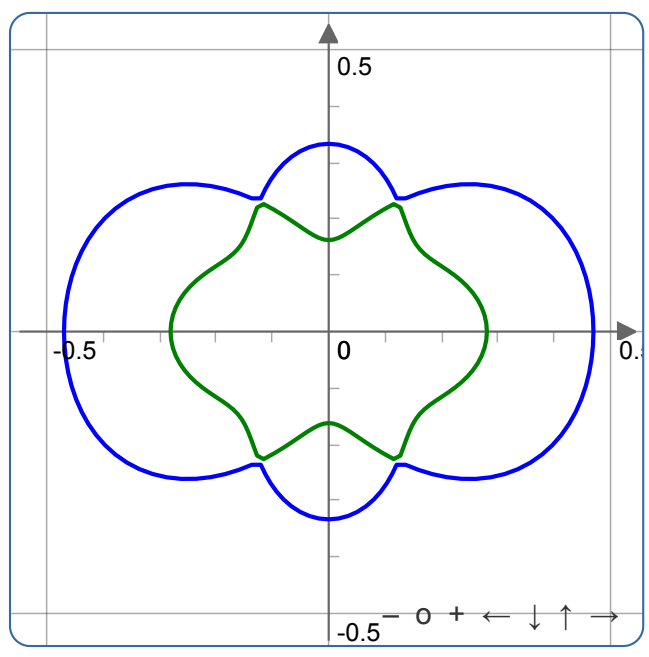

Poisson's ratio in (yz) plane

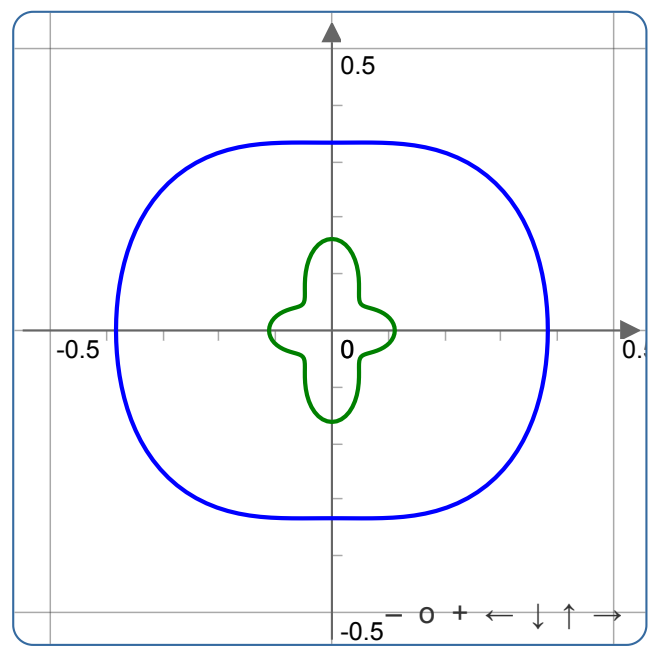

Poisson's ratio in (xz) plane

Code version: 2019.01.09 (running on Python 3.7.2)

Execution time: 1.160 seconds

Specific (faster) code for orthorhombic case was used. 


\section{ELATE: Elastic tensor analysis}

Welcome to ELATE, the online tool for analysis of elastic tensors, developed by Romain Gaillac and François-Xavier Coudert at CNRS / Chimie ParisTech.

If you use the software in published results (paper, conference, etc.), please cite the corresponding_paper ( $J$. Phys. Condens. Matter, 2016, 28, 275201) and give the website URL.

ELATE is open source software. Any queries or comments are welcome at fx.coudert@chimie-paristech.fr

\section{Summary of the properties}

Input: stiffness matrix (coefficients in GPa) of SrSeO4-Isz (25.083 GPa)

$\begin{array}{rrrrrr}217.01 & 137.41 & 118.03 & -37.47 & 0 & 0 \\ 137.41 & 217.01 & 118.03 & 37.47 & 0 & 0 \\ 118.03 & 118.03 & 211.98 & 2 \mathrm{e}-05 & 0 & 0 \\ -37.47 & 37.47 & 2 \mathrm{e}-05 & 73.414 & 0 & 0 \\ 0 & 0 & 0 & 0 & 64.854 & 4 \mathrm{e}-05 \\ 0 & 0 & 0 & 0 & 4 \mathrm{e}-05 & 64.854\end{array}$

\section{Average properties}

\begin{tabular}{|c|c|c|c|c|}
\hline $\begin{array}{c}\text { Averaging } \\
\text { scheme }\end{array}$ & Bulk modulus & $\begin{array}{c}\text { Young's } \\
\text { modulus }\end{array}$ & Shear modulus & Poisson's ratio \\
\hline Voigt & $\begin{array}{c}K_{\mathrm{V}}=154.77 \\
\mathrm{GPa}\end{array}$ & $E_{\mathrm{V}}=156.55 \mathrm{GPa}$ & $G_{\mathrm{V}}=58.793 \mathrm{GPa}$ & $v_{\mathrm{V}}=0.33141$ \\
\hline Reuss & $\begin{array}{c}K_{\mathrm{R}}=154.34 \\
\mathrm{GPa}\end{array}$ & $E_{\mathrm{R}}=110.4 \mathrm{GPa}$ & $\mathrm{G}_{\mathrm{R}}=39.976 \mathrm{GPa}$ & $v_{\mathrm{R}}=0.38079$ \\
\hline Hill & $\begin{array}{c}K_{\mathrm{H}}=154.56 \\
\mathrm{GPa}\end{array}$ & $E_{\mathrm{H}}=133.89 \mathrm{GPa}$ & $\mathrm{G}_{\mathrm{H}}=49.384 \mathrm{GPa}$ & $v_{\mathrm{H}}=0.35562$ \\
\hline
\end{tabular}

Eigenvalues of the stiffness matrix

\begin{tabular}{|c|c|c|c|c|c|}
\hline $\boldsymbol{\lambda}_{\mathbf{1}}$ & $\boldsymbol{\lambda}_{\mathbf{2}}$ & $\boldsymbol{\lambda}_{\mathbf{3}}$ & $\boldsymbol{\lambda}_{\mathbf{4}}$ & $\boldsymbol{\lambda}_{\mathbf{5}}$ & $\boldsymbol{\lambda}_{\mathbf{6}}$ \\
\hline $23.426 \mathrm{GPa}$ & $64.854 \mathrm{GPa}$ & $64.854 \mathrm{GPa}$ & $101.72 \mathrm{GPa}$ & $129.59 \mathrm{GPa}$ & $464.68 \mathrm{GPa}$ \\
\hline
\end{tabular}

Variations of the elastic moduli

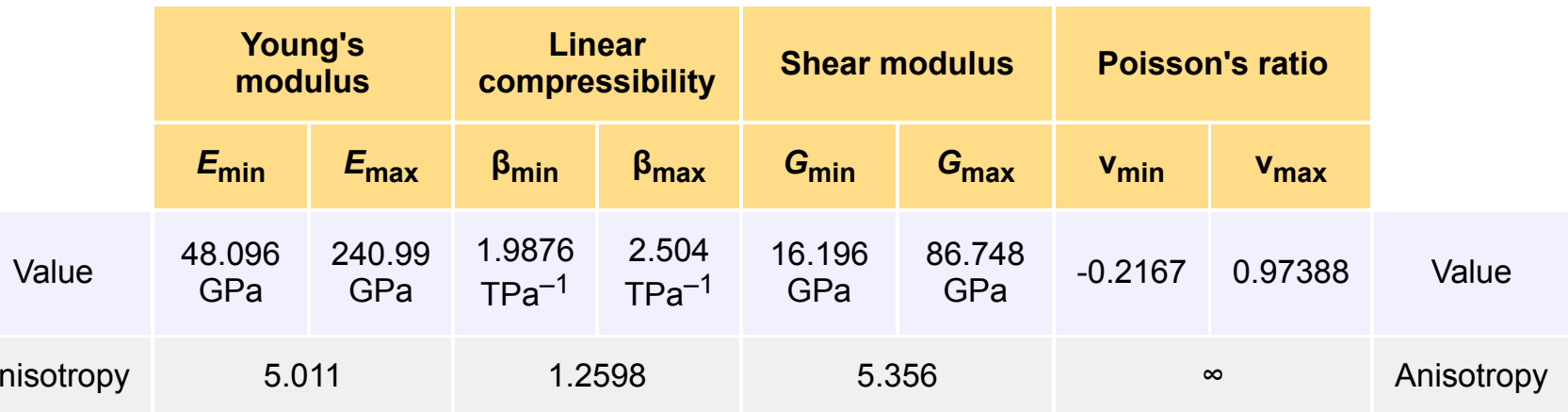




\begin{tabular}{|c|c|c|c|c|c|c|c|c|c|}
\hline Axis & $\begin{array}{c}0.0000 \\
0.9049 \\
-0.4257\end{array}$ & $\begin{array}{l}0.0000 \\
0.8028 \\
0.5962\end{array}$ & $\begin{array}{l}1.0000 \\
0.0000 \\
0.0000\end{array}$ & $\begin{array}{l}0.0000 \\
0.0000 \\
1.0000\end{array}$ & $\begin{array}{r}-0.7071 \\
0.6295 \\
-0.3222\end{array}$ & $\begin{array}{c}-0.4804 \\
0.2711 \\
0.8341\end{array}$ & $\begin{array}{l}0.5419 \\
0.4081 \\
0.7348\end{array}$ & $\begin{array}{l}-0.7641 \\
0.2704 \\
0.5857\end{array}$ & Axis \\
\hline & & & & & $\begin{array}{c}-0.7071 \\
-0.6294 \\
0.3221\end{array}$ & $\begin{array}{c}-0.4804 \\
-0.8770 \\
0.0084\end{array}$ & $\begin{array}{c}-0.8388 \\
0.2070 \\
0.5036\end{array}$ & $\begin{array}{c}0.0074 \\
-0.9042 \\
0.4270\end{array}$ & $\begin{array}{l}\text { Second } \\
\text { axis }\end{array}$ \\
\hline
\end{tabular}

\section{Spatial dependence of Young's modulus}

\section{Visualize in 3D}

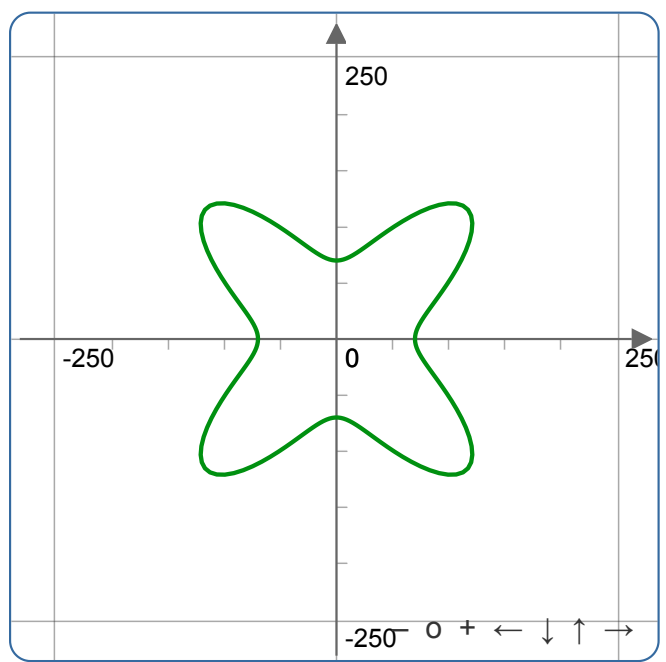

Young's modulus in (xy) plane

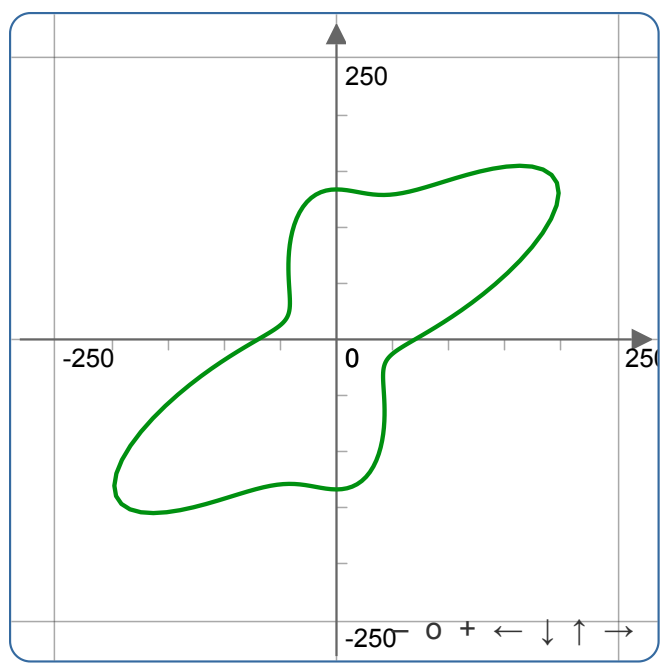

Young's modulus in (yz) plane

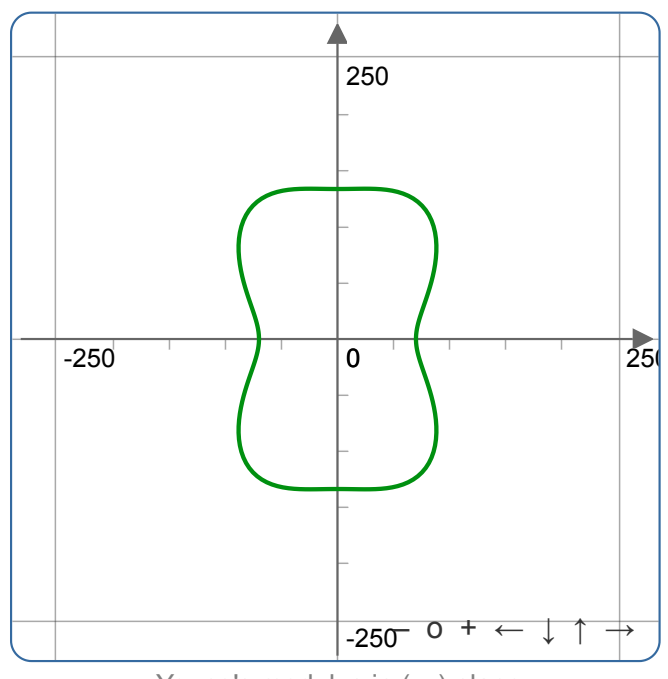

Young's modulus in (xz) plane

\section{Spatial dependence of linear compressibility}




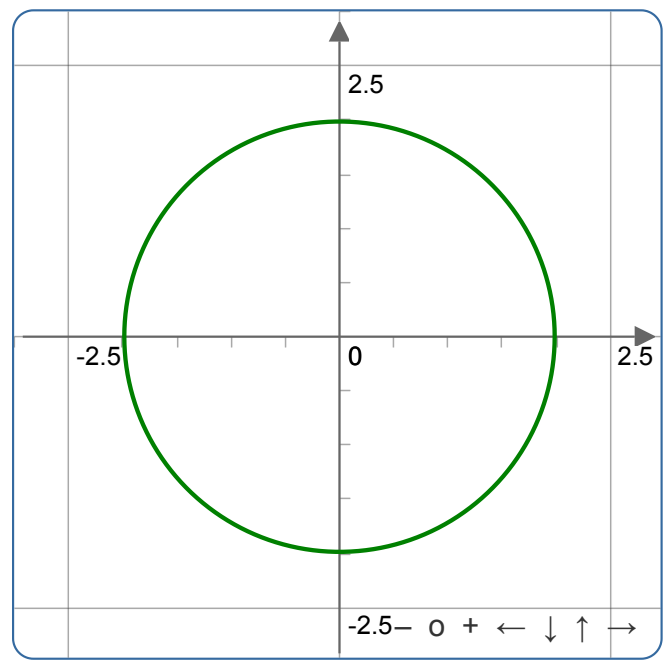

linear compressibility in (xy) plane

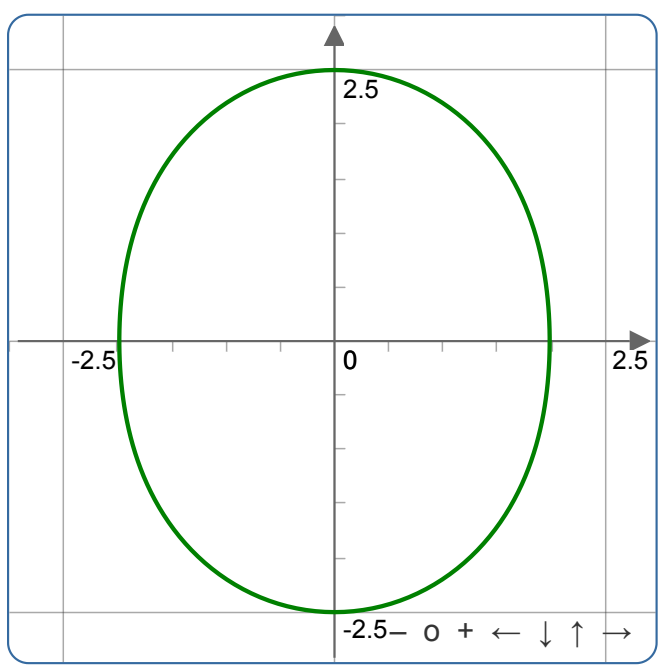

linear compressibility in (yz) plane

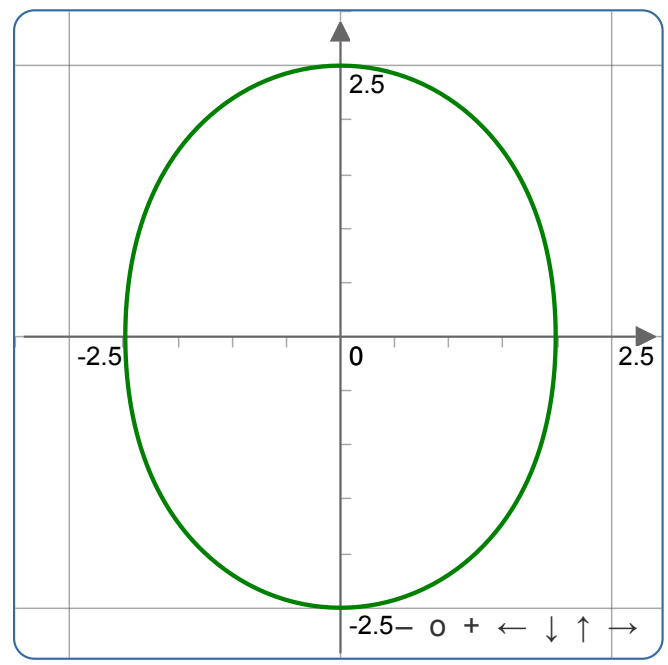

linear compressibility in (xz) plane

\section{Spatial dependence of shear modulus}

Visualize in 3D 


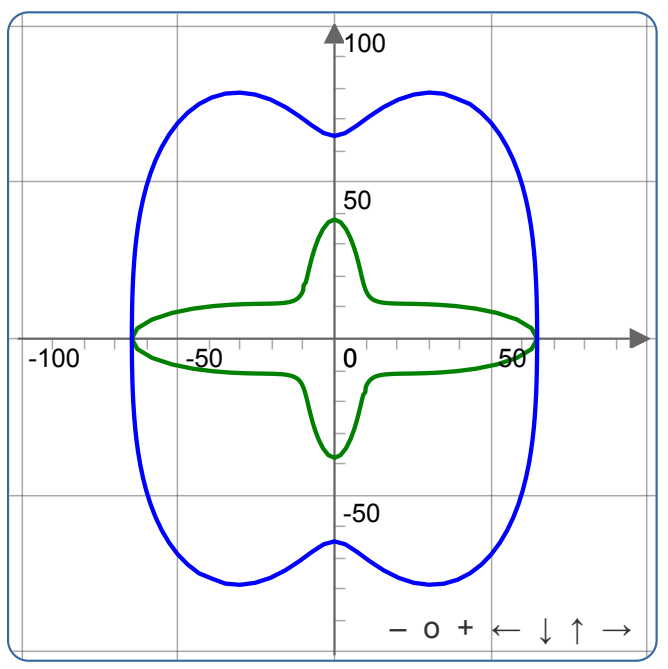

Shear modulus in (xy) plane

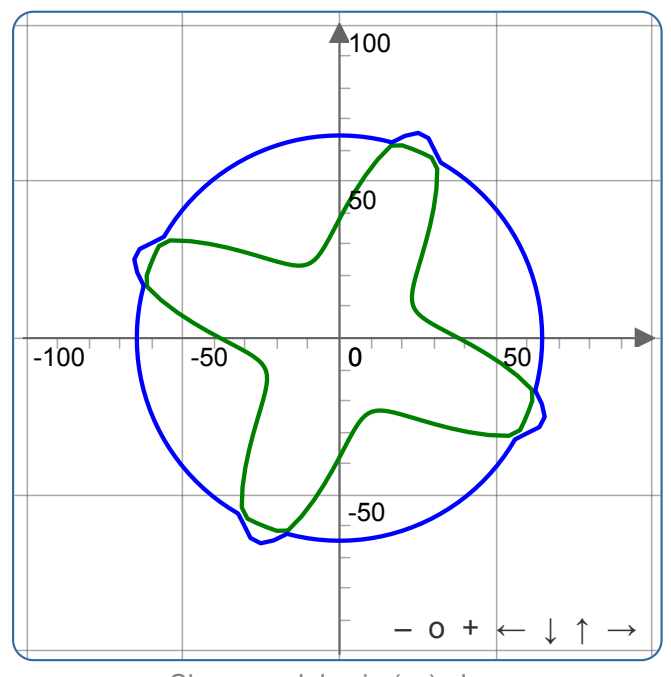

Shear modulus in (yz) plane

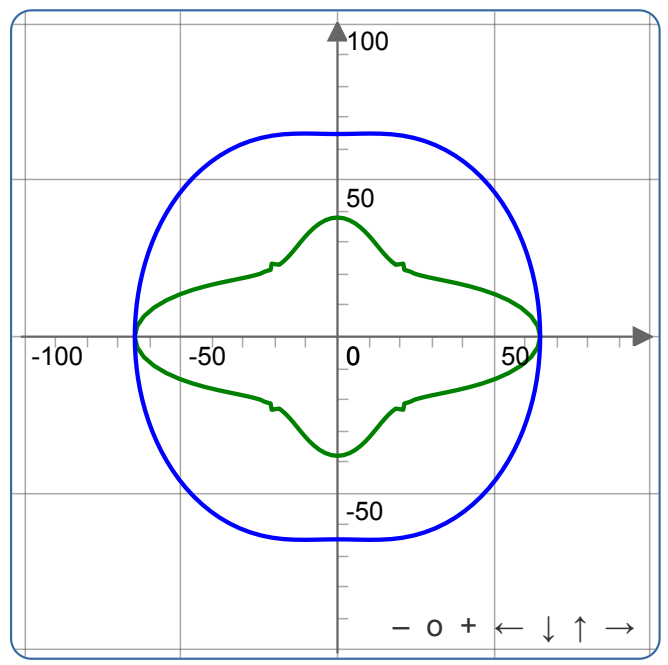

Shear modulus in (xz) plane

\section{Spatial dependence of Poisson's ratio}

\section{Visualize in 3D}




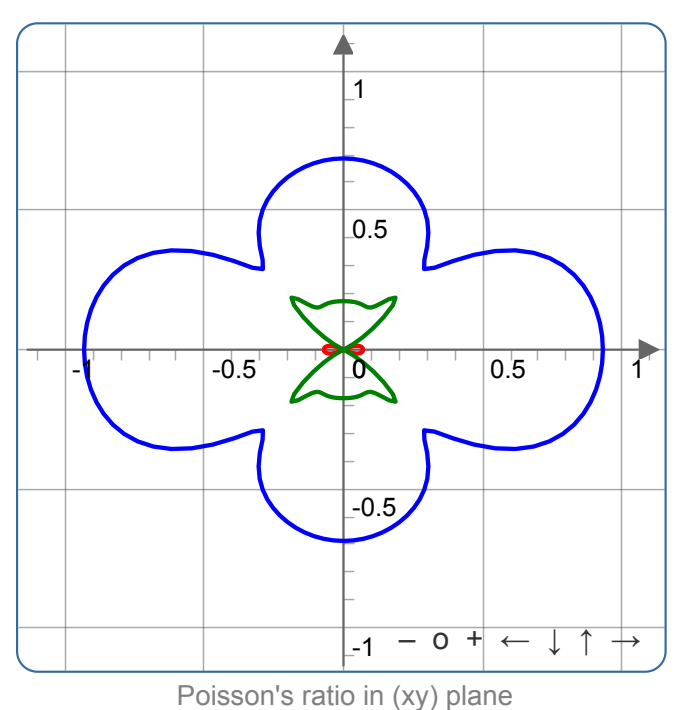

Poisson's ratio in (ky) plane

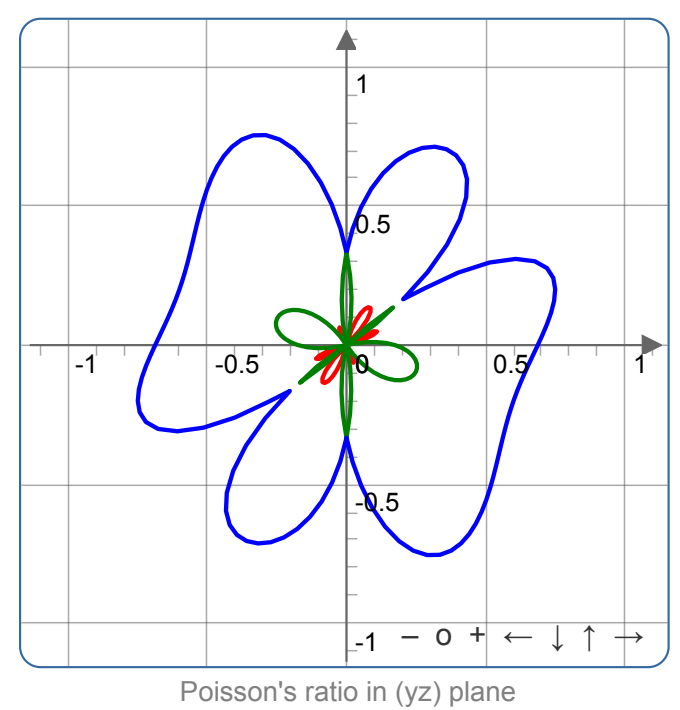

Poisson's ratio in (byz) plane

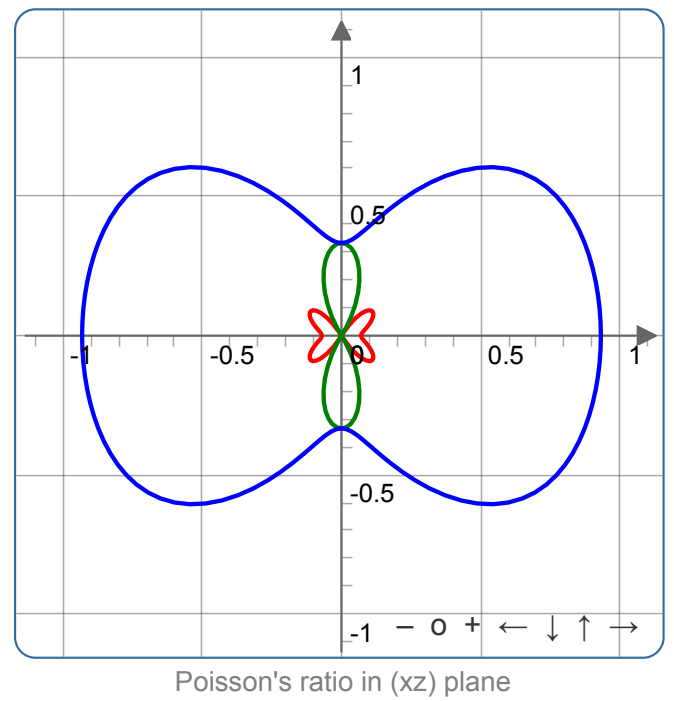

Poisson's ratio in $(x z)$ plane

Code version: 2019.01 .09 (running on Python 3.7.2) Execution time: 3.480 seconds 


\section{ELATE: Elastic tensor analysis}

Welcome to ELATE, the online tool for analysis of elastic tensors, developed by Romain Gaillac and François-Xavier Coudert at CNRS / Chimie ParisTech.

If you use the software in published results (paper, conference, etc.), please cite the corresponding_paper ( $J$.

Phys. Condens. Matter, 2016, 28, 275201) and give the website URL.

ELATE is open source software. Any queries or comments are welcome at fx.coudert@chimie-paristech.fr

\section{Summary of the properties}

Input: stiffness matrix (coefficients in GPa) of SrSeO4-hxg-d-8-Pbcm (29.781 GPa)

$\begin{array}{rrrrrr}165.09 & 113.4 & 74.152 & 0 & 0 & 0 \\ 113.4 & 232.56 & 110.96 & 0 & 0 & 0 \\ 74.152 & 110.96 & 249.18 & 0 & 0 & 0 \\ 0 & 0 & 0 & 84.907 & 0 & 0 \\ 0 & 0 & 0 & 0 & 75.506 & 0 \\ 0 & 0 & 0 & 0 & 0 & 44.087\end{array}$

\section{Average properties}

\begin{tabular}{|c|c|c|c|c|}
\hline Averaging scheme & Bulk modulus & Young's modulus & Shear modulus & Poisson's ratio \\
\hline Voigt & $K_{V}=138.21 \mathrm{GPa}$ & $E_{\mathrm{V}}=166.6 \mathrm{GPa}$ & $G_{V}=64.121 \mathrm{GPa}$ & $v_{V}=0.29909$ \\
\hline Reuss & $K_{\mathrm{R}}=130.75 \mathrm{GPa}$ & $E_{\mathrm{R}}=151.83 \mathrm{GPa}$ & $G_{\mathrm{R}}=58.107 \mathrm{GPa}$ & $V_{\mathrm{R}}=0.30646$ \\
\hline Hill & $K_{\mathrm{H}}=134.48 \mathrm{GPa}$ & $E_{\mathrm{H}}=159.22 \mathrm{GPa}$ & $G_{\mathrm{H}}=61.114 \mathrm{GPa}$ & $V_{\mathrm{H}}=0.30267$ \\
\hline
\end{tabular}

Eigenvalues of the stiffness matrix

\begin{tabular}{|c|c|c|c|c|c|}
\hline $\boldsymbol{\lambda}_{\mathbf{1}}$ & $\boldsymbol{\lambda}_{\mathbf{2}}$ & $\boldsymbol{\lambda}_{\mathbf{3}}$ & $\boldsymbol{\lambda}_{\mathbf{4}}$ & $\boldsymbol{\lambda}_{\mathbf{5}}$ & $\boldsymbol{\lambda}_{\mathbf{6}}$ \\
\hline $44.087 \mathrm{GPa}$ & $75.506 \mathrm{GPa}$ & $80.01 \mathrm{GPa}$ & $84.907 \mathrm{GPa}$ & $146.06 \mathrm{GPa}$ & $420.75 \mathrm{GPa}$ \\
\hline
\end{tabular}

Variations of the elastic moduli

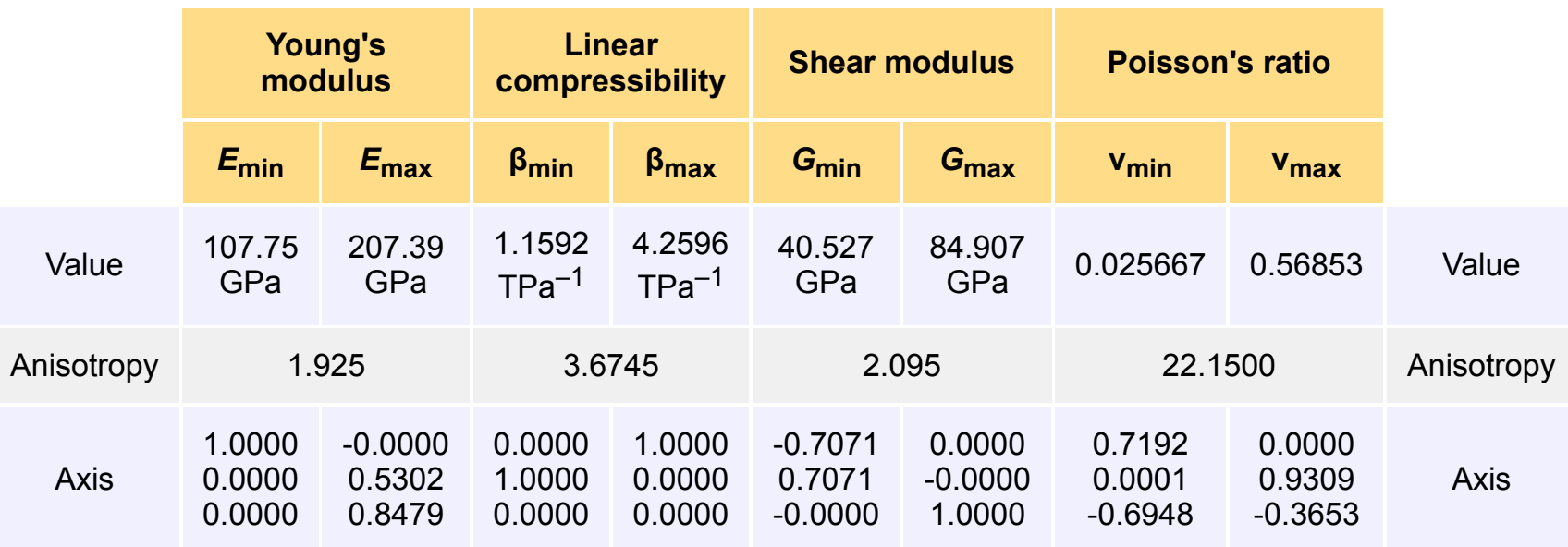




\begin{tabular}{|c|c|c|c|c|}
\hline-0.7071 & -0.0000 & -0.6948 & -1.0000 & Second \\
-0.7071 & -1.0000 & -0.0001 & 0.0000 & axis \\
\hline-0.0000 & -0.0000 & -0.7192 & 0.0000 &
\end{tabular}

\section{Spatial dependence of Young's modulus}

\section{Visualize in 3D}

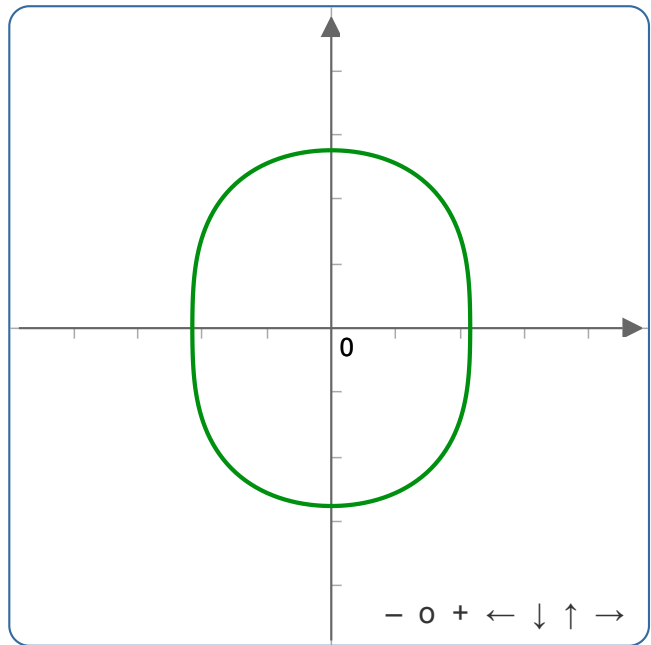

Young's modulus in (xy) plane

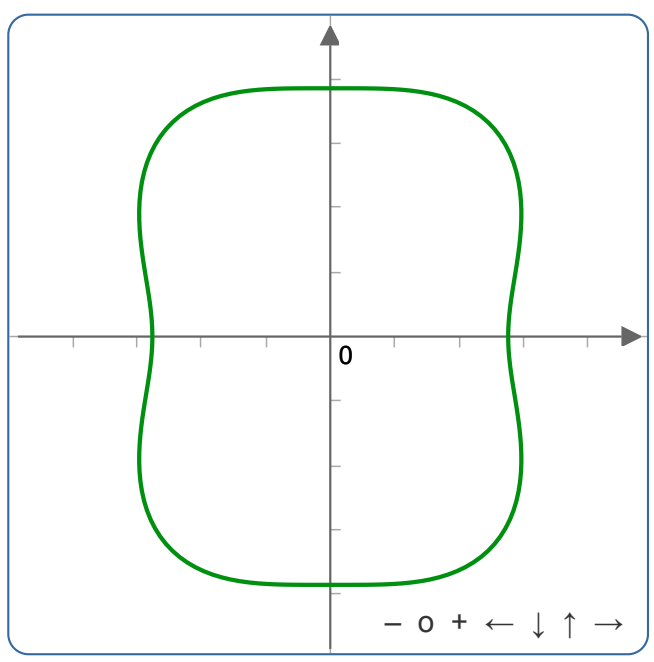

Young's modulus in (yz) plane

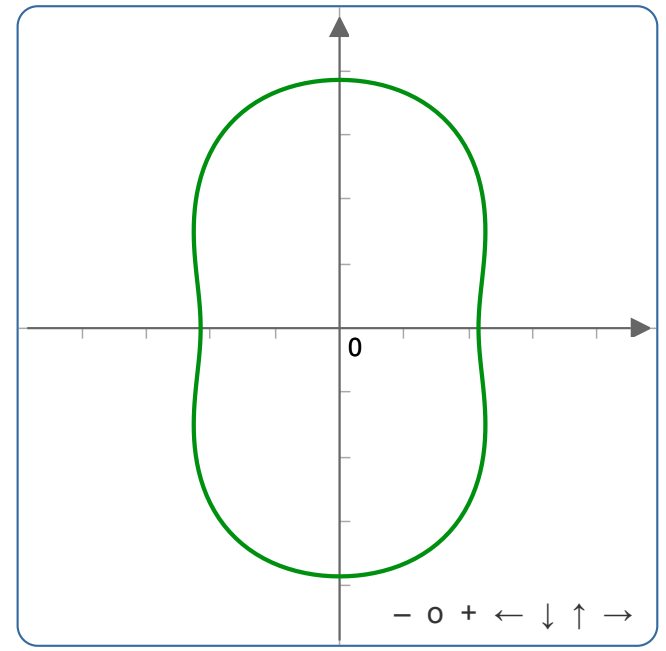

Young's modulus in (xz) plane

\section{Spatial dependence of linear compressibility}

\section{Visualize in 3D}




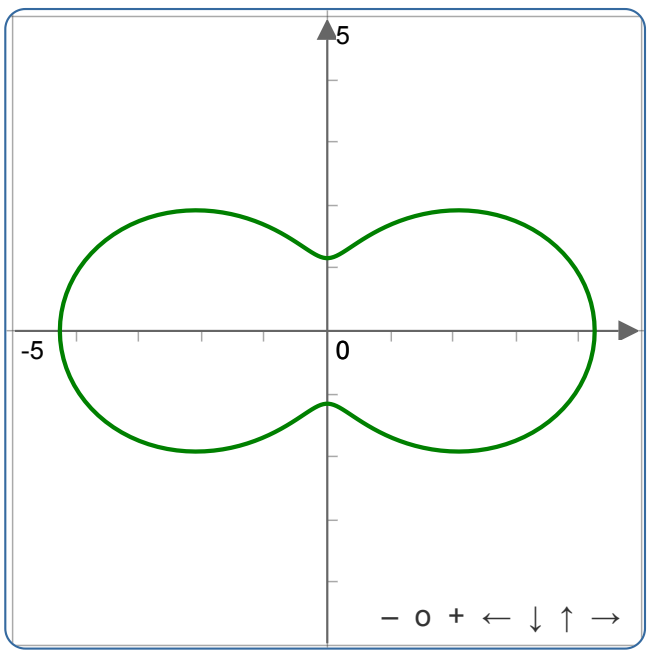

linear compressibility in (xy) plane

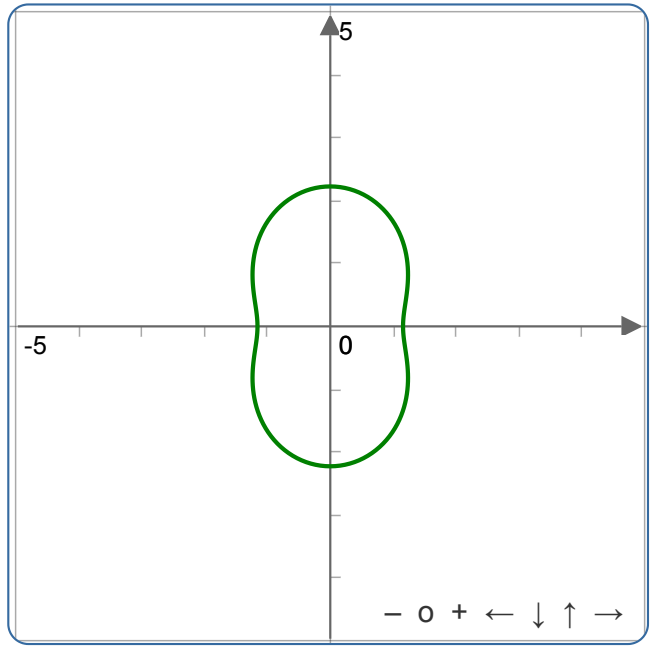

linear compressibility in (yz) plane

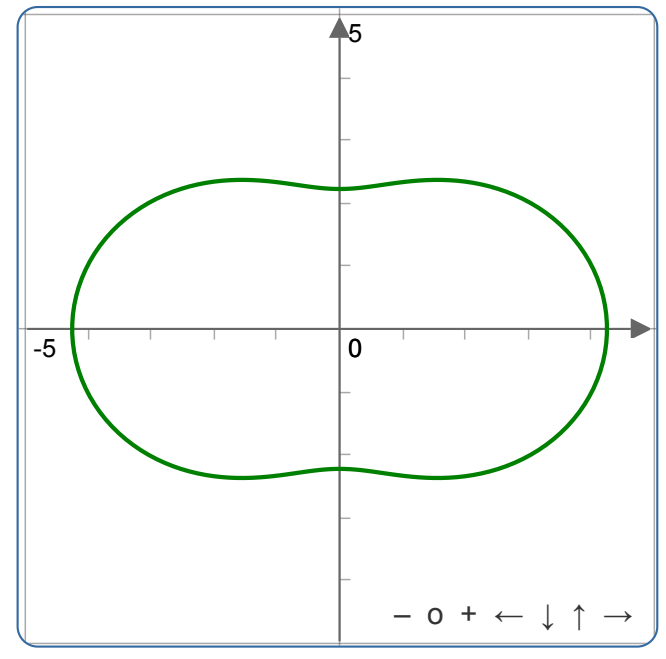

linear compressibility in (xz) plane

\section{Spatial dependence of shear modulus}

Visualize in 3D 


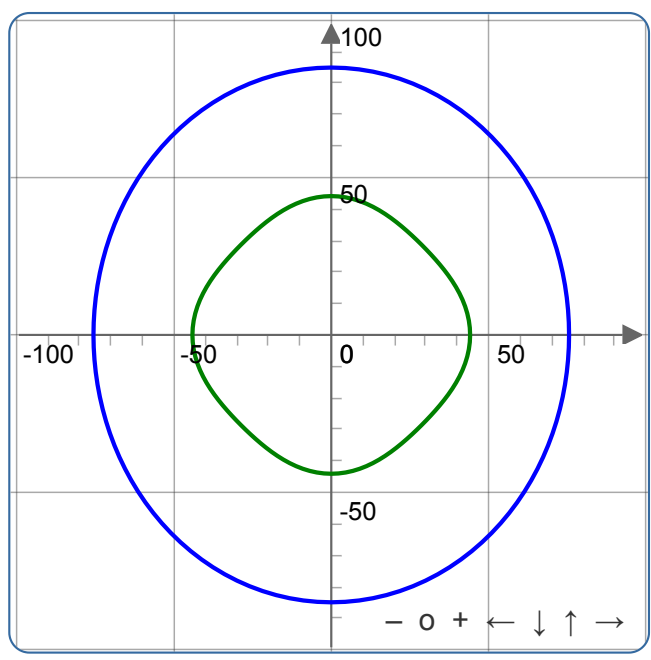

Shear modulus in (xy) plane

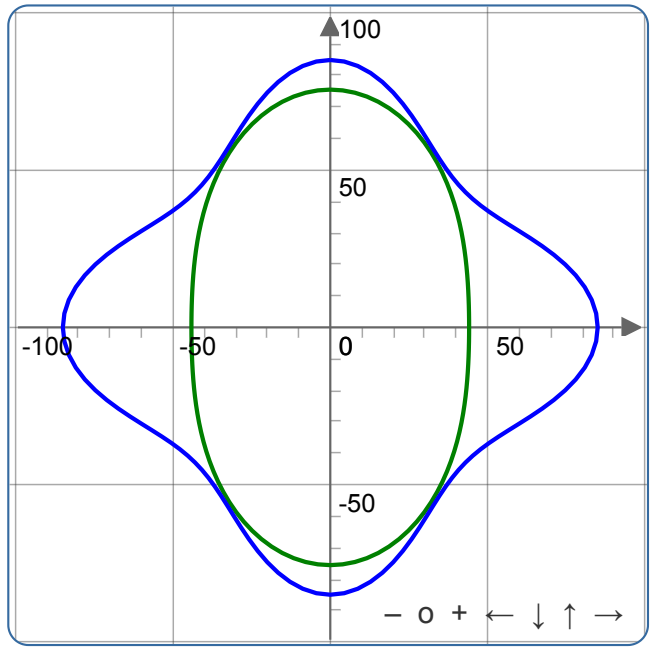

Shear modulus in (yz) plane

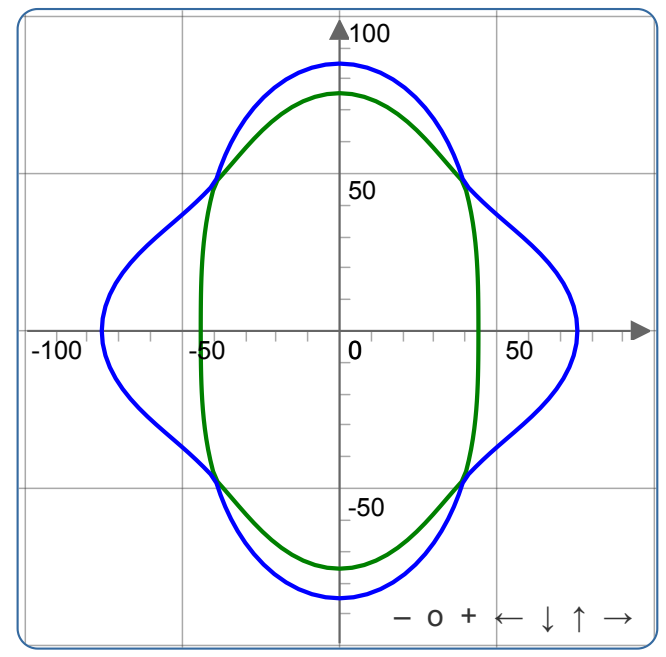

Shear modulus in (xz) plane

\section{Spatial dependence of Poisson's ratio}




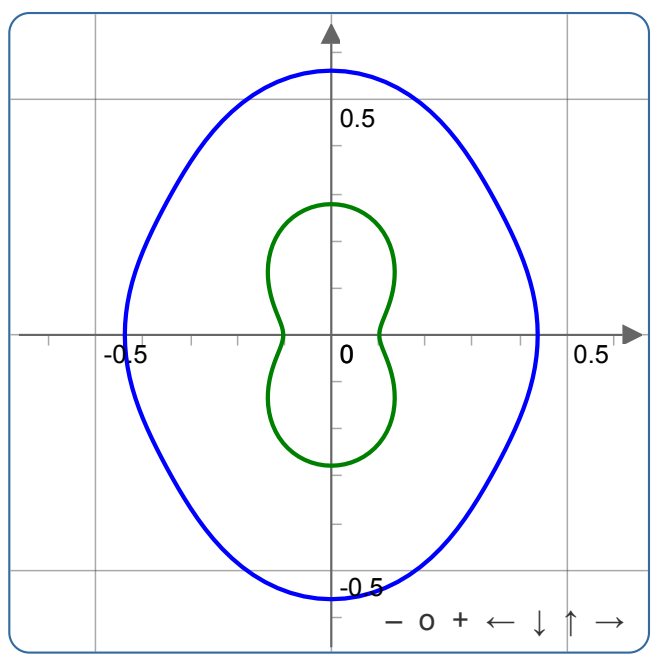

Poisson's ratio in (xy) plane

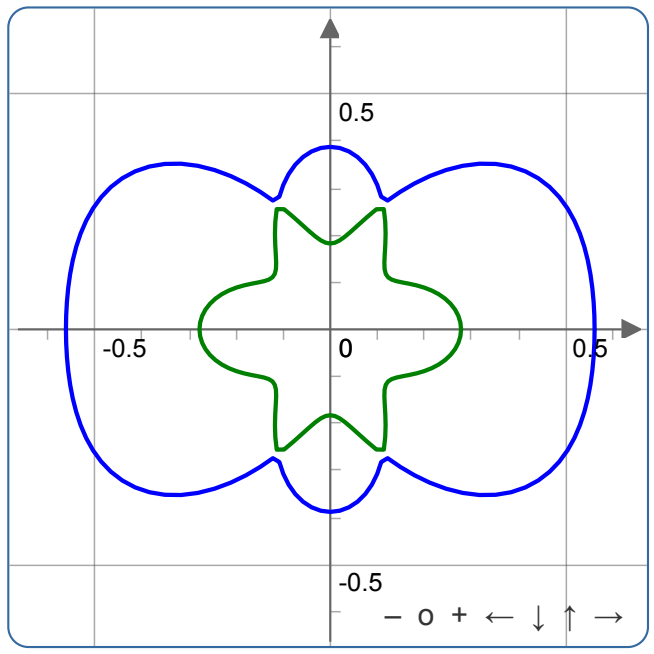

Poisson's ratio in (yz) plane

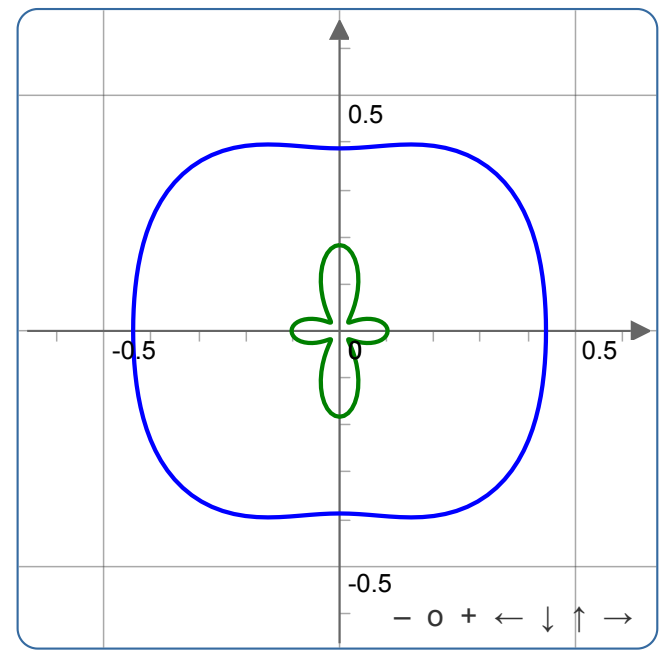

Poisson's ratio in (xz) plane

Code version: 2019.01 .09 (running on Python 3.7.2)

Execution time: 1.200 seconds

Specific (faster) code for orthorhombic case was used. 


\section{ELATE: Elastic tensor analysis}

Welcome to ELATE, the online tool for analysis of elastic tensors, developed by Romain Gaillac and François-Xavier Coudert at CNRS / Chimie ParisTech.

If you use the software in published results (paper, conference, etc.), please cite the corresponding_paper ( $J$.

Phys. Condens. Matter, 2016, 28, 275201) and give the website URL.

ELATE is oppen source software. Any queries or comments are welcome at fx.coudert@ $\underline{\text { chimie-paristech.fr }}$

\section{Summary of the properties}

Input: stiffness matrix (coefficients in GPa) of BaSeO4-hxg-d-8-Pbcm (15.403 GPa)

$\begin{array}{rrrrrr}118.74 & 78.943 & 36.863 & 0 & 0 & 0 \\ 78.943 & 169.32 & 62.162 & 0 & 0 & 0 \\ 36.863 & 62.162 & 165.58 & 0 & 0 & 0 \\ 0 & 0 & 0 & 60.656 & 0 & 0 \\ 0 & 0 & 0 & 0 & 48.956 & 0 \\ 0 & 0 & 0 & 0 & 0 & 37.053\end{array}$

\section{Average properties}

\begin{tabular}{|c|c|c|c|c|}
\hline Averaging scheme & Bulk modulus & Young's modulus & Shear modulus & Poisson's ratio \\
\hline Voigt & $K_{V}=89.953 \mathrm{GPa}$ & $E_{\mathrm{V}}=121.63 \mathrm{GPa}$ & $G_{V}=47.711 \mathrm{GPa}$ & $v_{V}=0.27464$ \\
\hline Reuss & $K_{\mathrm{R}}=84.999 \mathrm{GPa}$ & $E_{\mathrm{R}}=112.89 \mathrm{GPa}$ & $G_{\mathrm{R}}=44.145 \mathrm{GPa}$ & $V_{\mathrm{R}}=0.27864$ \\
\hline Hill & $K_{\mathrm{H}}=87.476 \mathrm{GPa}$ & $E_{\mathrm{H}}=117.26 \mathrm{GPa}$ & $G_{\mathrm{H}}=45.928 \mathrm{GPa}$ & $V_{\mathrm{H}}=0.27658$ \\
\hline
\end{tabular}

Eigenvalues of the stiffness matrix

\begin{tabular}{|c|c|c|c|c|c|}
\hline$\lambda_{1}$ & $\lambda_{\mathbf{2}}$ & $\boldsymbol{\lambda}_{\mathbf{3}}$ & $\boldsymbol{\lambda}_{\mathbf{4}}$ & $\boldsymbol{\lambda}_{\mathbf{5}}$ & $\boldsymbol{\lambda}_{\mathbf{6}}$ \\
\hline $37.053 \mathrm{GPa}$ & $48.956 \mathrm{GPa}$ & $60.498 \mathrm{GPa}$ & $60.656 \mathrm{GPa}$ & $118.62 \mathrm{GPa}$ & $274.53 \mathrm{GPa}$ \\
\hline
\end{tabular}

Variations of the elastic moduli

\begin{tabular}{|c|c|c|c|c|c|c|c|c|c|}
\hline & \multicolumn{2}{|c|}{$\begin{array}{l}\text { Young's } \\
\text { modulus }\end{array}$} & \multicolumn{2}{|c|}{$\begin{array}{c}\text { Linear } \\
\text { compressibility }\end{array}$} & \multicolumn{2}{|c|}{ Shear modulus } & \multicolumn{2}{|c|}{ Poisson's ratio } & \\
\hline & $E_{\min }$ & $E_{\max }$ & $\beta_{\min }$ & $\beta_{\max }$ & $G_{\min }$ & $G_{\max }$ & $v_{\min }$ & $\mathbf{v}_{\max }$ & \\
\hline Value & $\begin{array}{l}81.497 \\
\mathrm{GPa}\end{array}$ & $\begin{array}{c}147.45 \\
\mathrm{GPa}\end{array}$ & $\begin{array}{l}1.5487 \\
\mathrm{TPa}^{-1}\end{array}$ & $\begin{array}{l}6.1209 \\
\mathrm{TPa}^{-1}\end{array}$ & $\begin{array}{l}30.765 \\
\mathrm{GPa}\end{array}$ & $\begin{array}{c}60.656 \\
\mathrm{GPa}\end{array}$ & 0.055204 & 0.58901 & Value \\
\hline Anisotropy & \multicolumn{2}{|c|}{1.809} & \multicolumn{2}{|c|}{3.9523} & \multicolumn{2}{|c|}{1.972} & \multicolumn{2}{|c|}{10.6698} & Anisotropy \\
\hline Axis & $\begin{array}{l}1.0000 \\
0.0000 \\
0.0000\end{array}$ & $\begin{array}{c}-0.0000 \\
0.4936 \\
0.8697\end{array}$ & $\begin{array}{l}0.0000 \\
1.0000 \\
0.0000\end{array}$ & $\begin{array}{l}1.0000 \\
0.0000 \\
0.0000\end{array}$ & $\begin{array}{c}-0.7071 \\
0.7071 \\
-0.0000\end{array}$ & $\begin{array}{l}0.0003 \\
0.0003 \\
1.0000\end{array}$ & $\begin{array}{r}1.0000 \\
-0.0000 \\
0.0000\end{array}$ & $\begin{array}{r}-0.0000 \\
1.0000 \\
-0.0000\end{array}$ & Axis \\
\hline
\end{tabular}




\section{Spatial dependence of Young's modulus}

\section{Visualize in 3D}

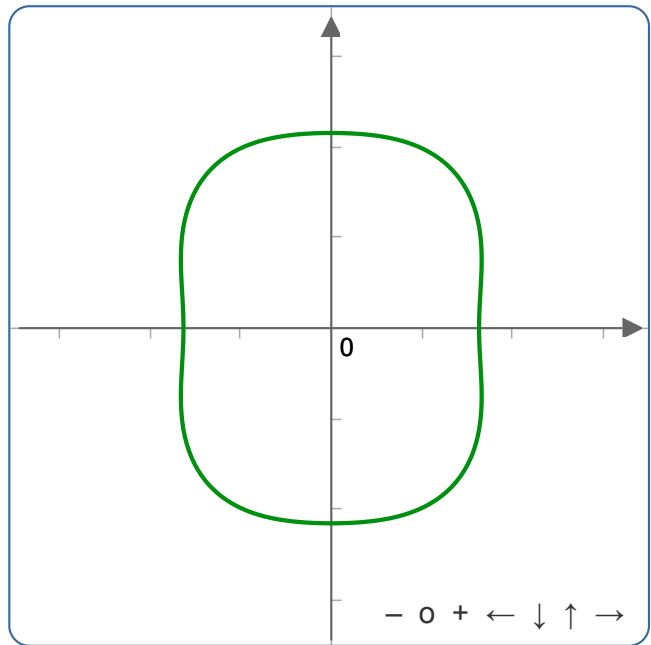

Young's modulus in (xy) plane

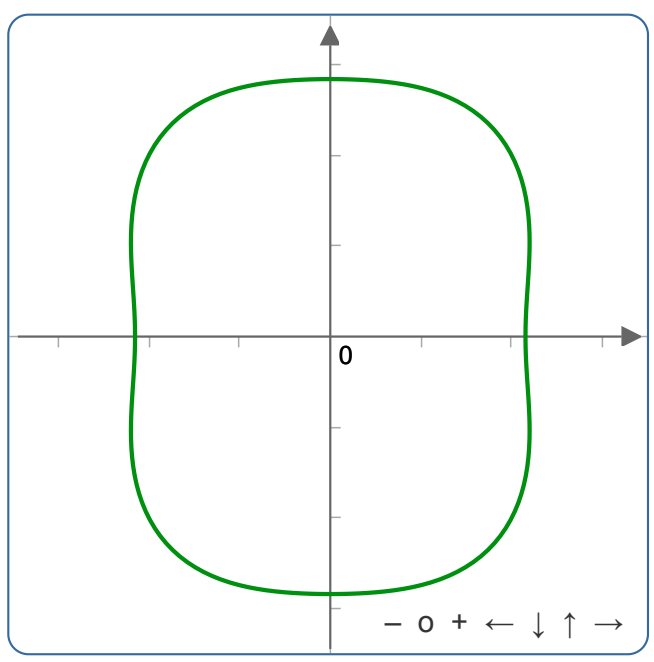

Young's modulus in (yz) plane

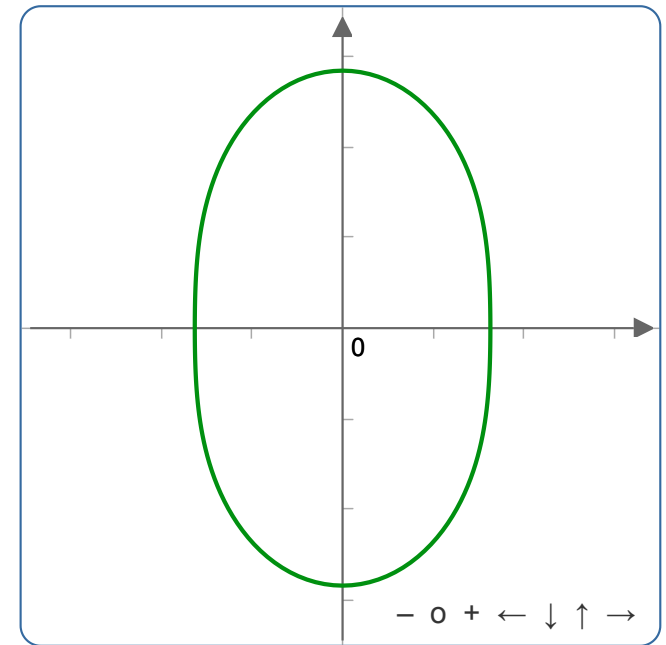

Young's modulus in (xz) plane

\section{Spatial dependence of linear compressibility}

\section{Visualize in 3D}




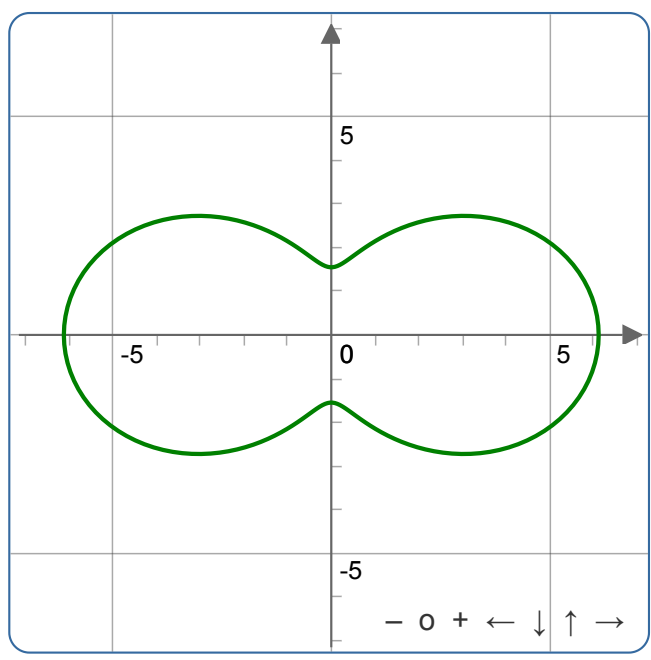

linear compressibility in (xy) plane

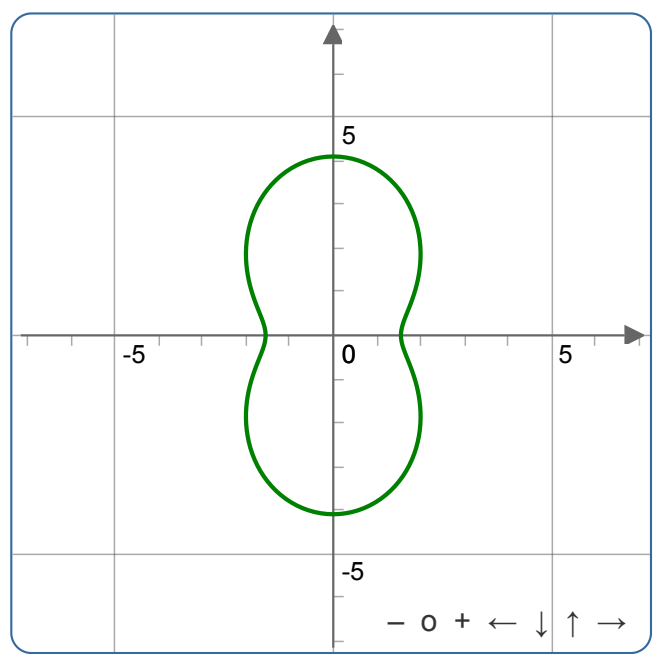

linear compressibility in (yz) plane

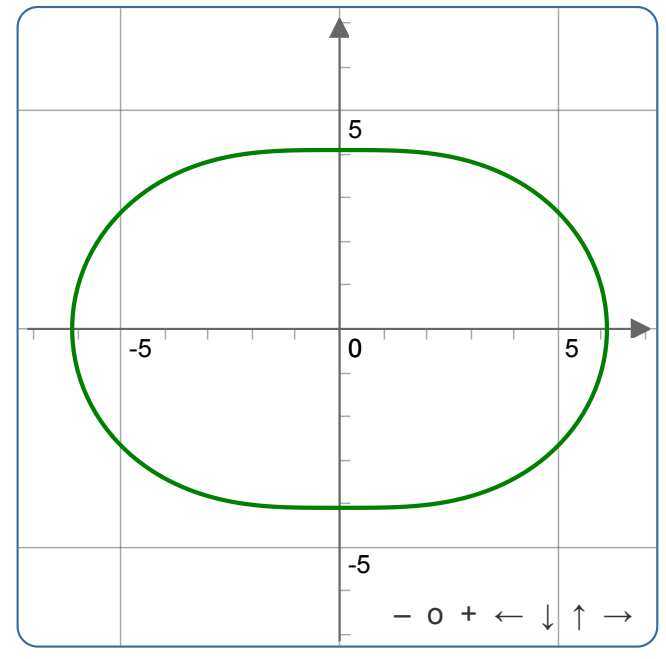

linear compressibility in (xz) plane

\section{Spatial dependence of shear modulus}




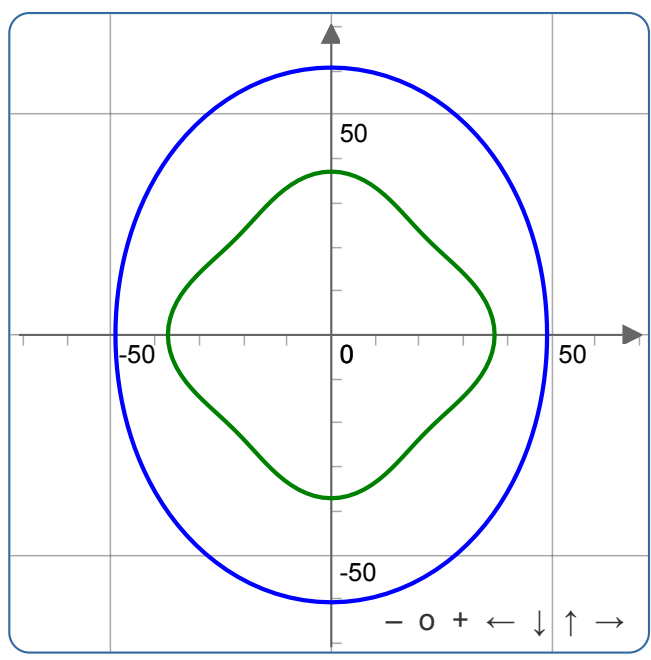

Shear modulus in (xy) plane

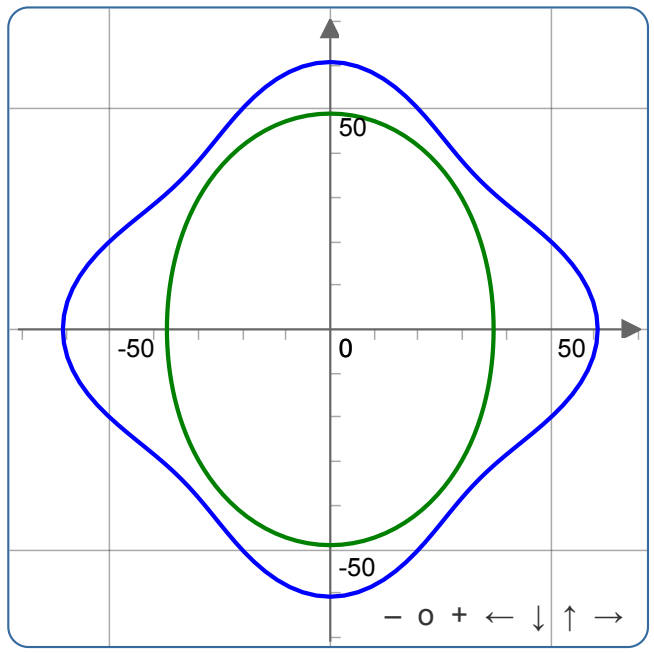

Shear modulus in (yz) plane

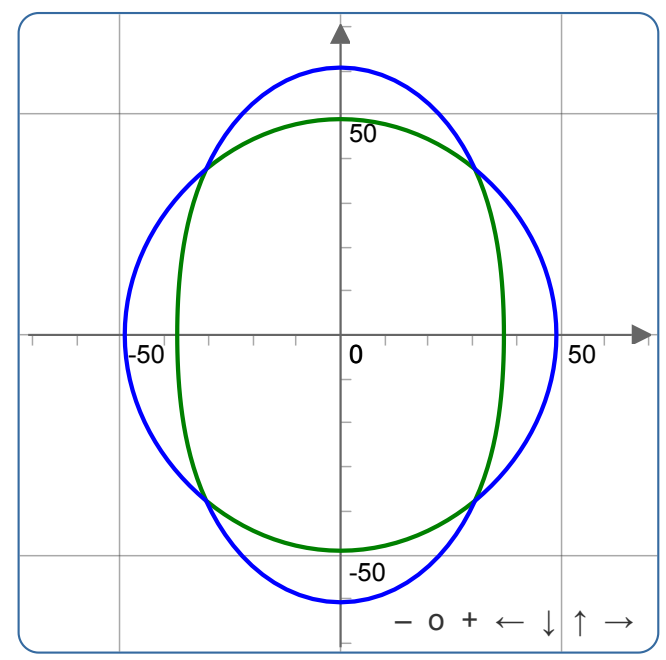

Shear modulus in (xz) plane

\section{Spatial dependence of Poisson's ratio}




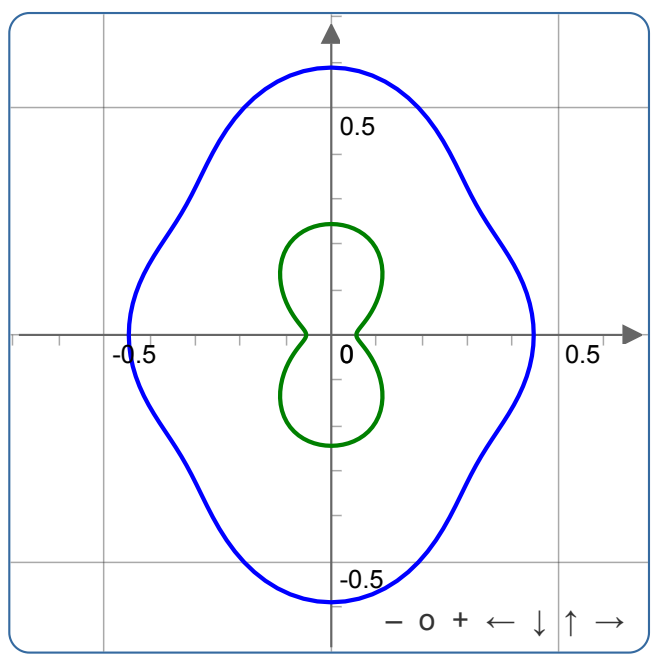

Poisson's ratio in (xy) plane

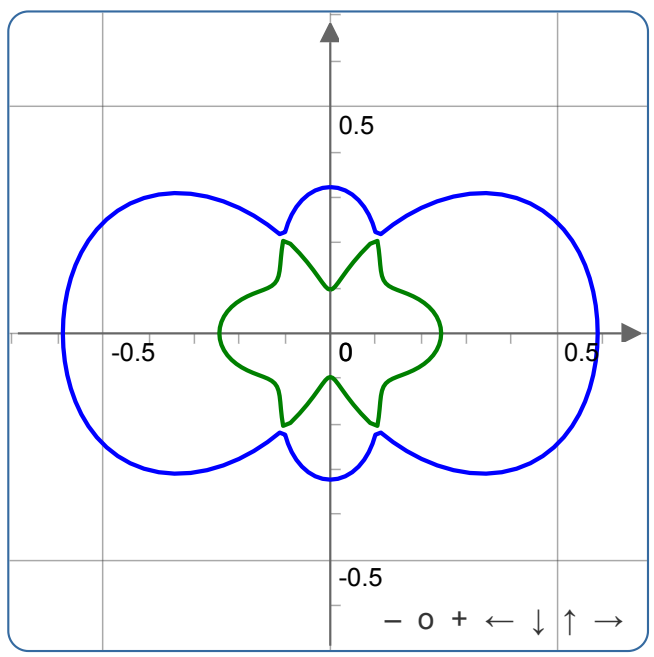

Poisson's ratio in (yz) plane

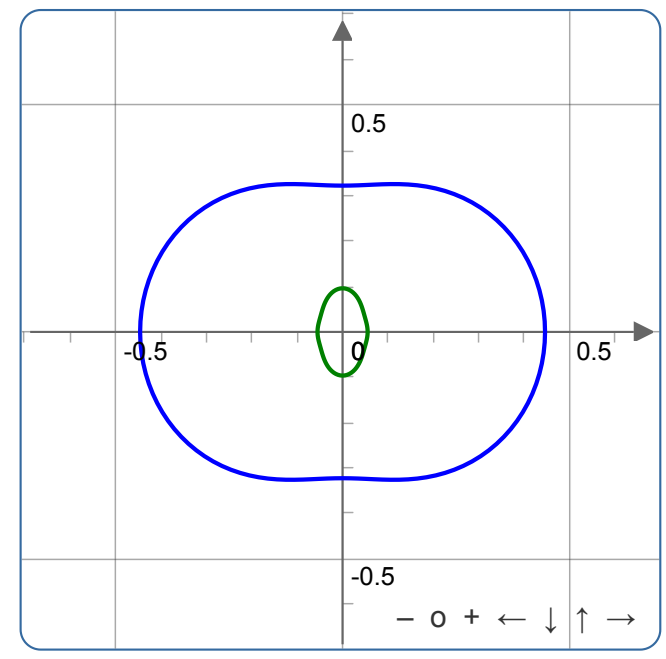

Poisson's ratio in (xz) plane

Code version: 2019.01 .09 (running on Python 3.7.2)

Execution time: 1.170 seconds

Specific (faster) code for orthorhombic case was used. 